\title{
RYBY A PÔST V ZOBORSKOM KLÁŠTORE PRI NITRE VO SVETLE ARCHEOZOOLOGICKÝCH DOKLADOV ${ }^{1}$
}

\author{
Zora Bielichová - Marián Samuel - Karol Hensel
}

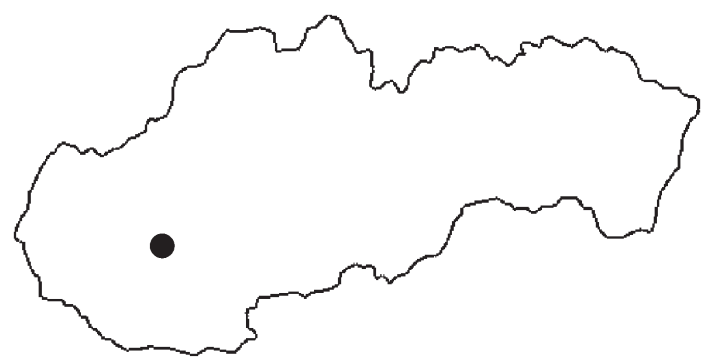

DOI: https://doi.org/10.31577/szausav.2019.65.8

Key words: Nitra, Zobor Monastery, Camaldoli, diet, fish, crawfish, tortoise, $17^{\text {th }}-18^{\text {th }}$ century

Fish and Fasting in the Zobor Monastery in Nitra in the Light of Archaeozoological Evidence

The paper presents the first results of the analysis of archaeofaunal remains from the monastery at Nitra-Zobor site (SW Slovakia). The majority of the 5201 analysed specimens (five samples) came from the cellar and floors of two monk's houses from the Camaldulese Monastery of St. Joseph (1693-1782). The remainder originated from areas between the houses (one sample), layers connected to the construction and destruction of the baroque monastery (two samples), a single medieval feature (one sample) and unspecified contexts (two samples). The material is dominated by aquatic or semi-aquatic taxa (97.3\%) including fish (Pisces), crayfish (Astacus astacus), otter (Lutra lutra), beaver (Castor fiber) and the European pond turtle (Emys orbicularis). Only freshwater fish such pike (Esox lucius), carp (Cyprinus carpio), Danube catfish (Silurus glanis), sturgeon (Acipenser sp.), tench (Tinca tinca), dace (Leuciscus leuciscus), and bleak (Alburnus alburnus) were identified. Large-sized individuals predominate in the assemblage pointing to the anthropogenic selection of fish, and a wealth of natural resources or favourable artificial fishponds. The representation of skeletal elements from the head, trunk and fin indicate that complete fresh fish were brought to the site. Monks consumed whole or portions of fish (traces of butchery and chewing are recorded). The assemblage from house no. 9 had an exclusively fasting character, while house no. 3 yielded bones of domestic mammals - young sheep/goat, cattle, chicken, goose and turkey. The spatial differences are explained through the context of finds, when in the latter are related with the construction and destruction of the baroque monastery. The meat of domestic mammals was probably consumed in the monastery by service staff and other secular persons that often visited and used local public services.

\section{ÚVOD}

Primárnym cielom výskumu pozostatkov zvierat na archeologických lokalitách je rekonštrukcia stravovania a živočíšneho hospodárstva zaniknutých komunít. Okrem výživy a ekonomiky pomáha táto čast’ materiálnej kultúry definovał’ aj kultúrno-náboženské a sociálne aspekty ludskej existencie (Grau-Sologestoa 2016; ChoykelJaritz 2017; O'Day/Van Neer/Eroynck/2003; Pluskowski a i. 2010). Vypovedacie možnosti sú i vo výskume prírodných zdrojov a životného prostredia v minulosti (Braje/Rick 2013; Galik a i. 2015; Hoffman 2005; Makowieczki 2003a). Výsledky dosiahnuté analýzou časti archeofaunálnych zvyškov z lokality Nitra-Zobor majú presah do temer všetkých z uvedených tém. Sú primárnym prameňom pri štúdiu prejavov religiozity a identity (krestanský pôst, stravovanie v kláštornej komunite), lokálnej ekonomiky (chov zvierat, produkcia a spracovanie potravín) a prispievajú k poznaniu prírodných zdrojov minulosti (životné prostredie, regionálne zdroje).

O pôsobení kamaldulov v Zoborskom kláštore pri Nitre sa toho vie doposial' pomerne málo. Dostupnost̉ i vypovedacia hodnota písomných a ikonografických prameňov viažuca sa $k$ tomuto miestu i v tak nedávnej dobe, akým je 18. stor., je limitovaná (Branecký 1945; Cserenyei 1911; Judák 1997; 2009; Kompánek 1895, 111-114; Lacko 1965; 1967; Lombardini 1895; Vozár 1997). Detaily každodenného života kláštornej komunity zahŕňajúce stravovanie, zabezpečovanie potravín a hospodárske interakcie s okolitým svetom a prírodou zostávali zatial' z viacerých dôvodov mimo záujmu bádatelov. Tu sa ako perspektívne javia najmä nálezy a poznatky získané archeologickým výskumom. Ten v rámci záchranných i systematických

\footnotetext{
1 Práca vznikla s podporou grantových projektov VEGA 2/0001/18 a APVV-16-0449.
} 
kampaní prebieha s prestávkami na lokalite dodnes a nazhromaždil už istý materiálový fond nielen k barokovému, ale aj stredovekému kláštoru (súhrnne k archeologickým výskumom pozri Samuel 2010). Hoci ich komplexné vyhodnotenie zatial' nebolo publikované, niektoré výnimočné súbory z novoveku už prešli odbornou analýzou a dokladajú napríklad vybavenost pustovníckych domčekov a kontakty rehole $\mathrm{v}$ rámci Uhorska, rakúskej monarchie, ale aj mimo nej (Samuel 2009; Samuel/Čurný 2010).

Cielom tejto štúdie je sonda do stravovacích zvyklostí v Zoborskom kláštore na základe vyhodnotenia archeofaunálneho materiálu. Jeho unikátnost’ podčiarkuje fakt, že prevažná čast’ bola odkrytá $\mathrm{v}$ primárnej polohe, $\mathrm{v}$ pivnici (resp. murovanej šachte toalety) jedného z pustovníckych domčekov (asi $83 \%$ ). V práci analyzujeme sortiment a podiel jednotlivých živočíšnych druhov v stravovaní mníchov, ale aj špecifiká Zoborského kláštora $\mathrm{v}$ kontexte iných mestských, aristokratických, kláštorných sídiel v regióne Nitry a širšom európskom regióne. Ďalším cielom je získat indície o tých aktivitách v kláštore, ktoré sú spojené s produkciou a dovozom potravín (napr. konzervované nepôvodné druhy rýb), ale tiež skladovaním, kuchynským spracovaním či likvidáciou odpadu z primárnych (mäso/tuk) a sekundárnych produktov zvierat (vajcia, koža, kost̉ atd'). Literárne i ikonografické pramene svedčia o tom, že ekonomika kláštora mohla zahŕňat aj chovatel'stvo hospodárskych zvierat a rybnikárstvo, preto je dôležitou súčastou štúdie konfrontácia dostupných historických a novo získaných archeozoologických dát.

\section{KAMALDULI}

\section{Stručné dejiny rehole a kláštora pri Nitre}

Kamalduli, nazývaní aj „bieli benediktíni“, sú jednou z najprísnejších reholí rímskokatolíckej cirkvi. Tento kontemplatívny rád založil v roku 980 sv. Romuald (951?-1027). Inšpirovaný spôsobom života starovekých pustovníkov žijúcich v púšti sa v r. 1012 spolu s niekolkými spoločníkmi utiahol do etrurijských vrchov pri Arezze v Toskánsku, kde dostal od grófa Maldola územie (Campo di Maldolo), na ktorom si postavili kláštor. Názov tohoto územia sa preniesol do názvu kláštora a ujal sa aj pre pomenovanie celého rádu (kamalduli). Oficiálne bola existencia rádu potvrdená pápežom Alexanderom II. v roku 1072.

Mnohé kamaldulské kláštory $\mathrm{v}$ nasledujúcich storočiach opúštali mimoriadne prísny spôsob reholníctva a len malá čast' sa pridŕžala pôvodných regulí. Reakciou na tento stav bola reforma uskutočnená mníchom Paolom Gustinianim († 1528) na začiatku 16. stor. Vytvorili sa tak dve vetvy: nová, reformná, preferujúca prísny spôsob života s centrom v Monte Corona pri Perugii (Congregatio Eremitarum Camaldulensium Montis Coronae) a kongregácia kamaldulských mníchov (Congregatio Camaldoli) s volnejším spôsobom života. Práve z prostredia novej reformnej vetvy z Monte Corona vzišli zakladatelia všetkých kamaldulských kláštorov v Rakúskej monarchii vrátane Uhorska. Aj prvý reholníci na Zobore boli bývalí členovia pustovne v Monte Corona. Páter Don Ján Félix (prvý prior pustovne), R. P. Don Pacomius, R. P. Don Romuald a fráter Theobaldus boli podla všetkého Taliani (Vozár 1997, 87).

Rád kamaldulov sa v stredoeurópskom priestore etabloval až v novoveku (17. stor.), hoci prvý pokus tu pôsobit sa uskutočnil ešte počas života sv. Romualda. Ten spolu s 24 pustovníkmi podnikol okolo roku 1010 evanjelizačnú cestu do Uhorska, ale choroba ho donútila vrátit’ sa so siedmimi bratmi do Itálie (Lacko 1965; 1967, 147). Je prekvapujúce, že ani počas d’alších šiestich storočí rád kamaldulov nepôsobil inde než v Itálii. Až v 17. stor. prenikol do Rakúskej monarchie, Pol’ska a neskôr aj inde. V Rakúskej monarchii existovalo spolu pät kamaldulských kláštorov, z toho tri v Uhorsku. Všetky prináležali k reformnej kongregácii Monte Corona. Prvá a na dlhší čas jediná kamaldulská „pustovňa“, postavená k úcte sv. Jozefa, vznikla z vôle cisára Ferdinanda II. necelých 8 km od centra Viedne, na kopci Kahlenberg v roku 1628 (Hamminger 1986; Mulitzer 2014, 400). ${ }^{2}$ Výstavbu druhého kláštora v rakúskej časti monarchie zasväteného Michalovi archanjelovi na kopci pri Lánzséri v Šoproňskej župe ${ }^{3}$ fundovali v roku 1700 palatín Pavol Esterházy s manželkou Evou Thökölyovou (Mulitzer 2014, 428). V Uhorskej časti monarchie sa nachádzali tri kláštory. Prvý (1693) bol Kláštor sv. Jozefa v Nitre na kopci Zobor, d’alší vznikol taktiež z iniciatívy

\footnotetext{
2 V časti odbornej literatúry sa udáva nesprávny letopočet 1683, kedy mal cisár Leopold I. z vd’aky za vítazstvo nad Turkami založit prvú kamaldulskú pustovňu v monarchii (Judák 2009, 22; Lacko 1967, 148).

3 Dnes Landsee v rakúskej spolkovej krajine Burgenland.
} 


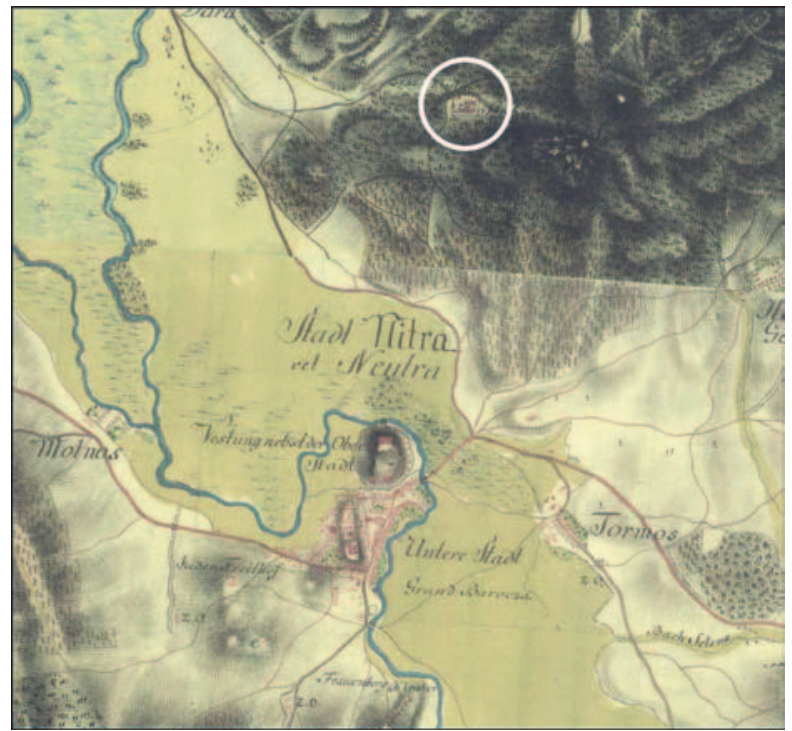

Obr. 1. Situovanie Zoborského kláštora na mape 1. vojenského mapovania (1782-1784).

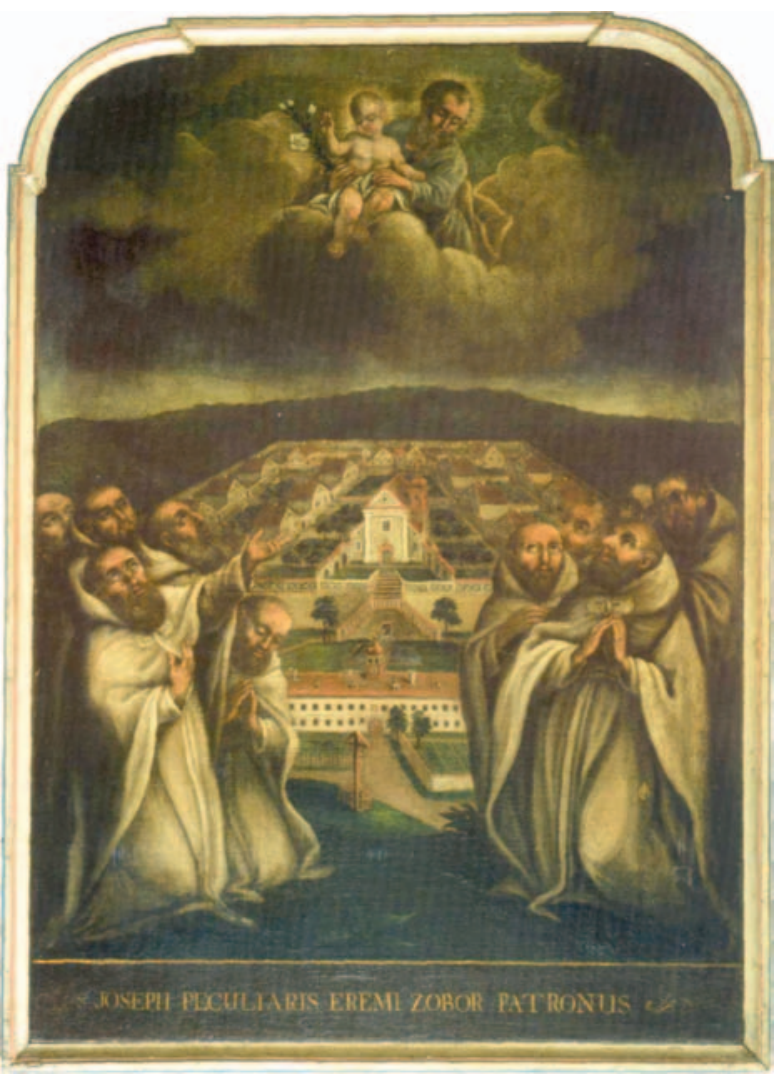

Obr. 2. Nitra, Zoborský kláštor. Olejomal'ba z druhej polovice 18. storočia zobrazujúca areál kamaldulského Kláštora sv. Jozefa. Nitrianska galéria, neznámy stredoeurópsky maliar. Inv. č. 0-81. Foto M. Samuel. nitrianskeho biskupa Ladislava Mat’ǎovského, následníka Blažeja Jaklina. Ten v roku 1705 daroval kamaldulskej reholi na fundovanie bývalý kartuziánsky kláštor $\mathrm{v}$ Lechnickej doline na Spiši, ktorý kúpil v roku 1699 od rodiny grófa Pavla Rákociho. Kláštor sv. Antona pustovníka mnísi zaujali až po akceptovaní ponuky biskupa generálnou kapitulou v roku 1710. Generálna kapitula zverila rekonštrukciu a adaptáciu starého kláštora zoborskému priorovi Jánovi Urminskému (Urményimu), ale nové cely sa mohli začat stavat' až po roku 1720, ked’ panovník Karol VI. po dlhom spore s kartuziánskym rádom pridelil majetok kamaldulom (Judák 2009, 26, 27; Števík/ Timková 2004, 40, 41). Tretí kamaldulský kláštor v Uhorsku, sv. Jána Nepomuckého (obr. 3: 5), zriadil gróf Jozef I. Esterházy v roku 1733 v Komárňanskej stolici pri obci Majk a bol v blízkosti zaniknutého kartuziánskeho kláštora (Mulitzer 2014, 446). Týchto pät kláštorov vytváralo organizačnú jednotku „Pustovne nemecko-uhorského národa" (Eremi Nationis Germano-Hungaricae). "Nemecko-uhorský národ“ bol jeden z piatich, na ktoré sa delila v 18. stor. kamaldulská kongregácia na Monte Corona (Lacko 1965, 102, 103). Dalšie „národy“ boli: cirkevný, resp. pápežský (v strednom Taliansku na území bývalého pápežského štátu), neapolský, benátsky a pol'ský. Okolo roku 1750 bolo v Európe spolu 30 funkčných kláštorov, z toho $18 \mathrm{v}$ Itálii, sedem ${ }^{4} \mathrm{v}$ Pol'sku a pät ${ }^{5}$ v Rakúsku (Mulitzer 2014, 16). Kamalduli v rakúskej monarchii vyvíjali svoju činnost' až do roku 1782, ked' panovník Jozef II. zrušil všetky kontemplatívne, z jeho pohladu neužitočné rády. Areál kláštora postupne pustol. Využívala sa a do dnešných čias sa zachovala len čast hlavnej hospodárskej budovy konventu, ruina kláštorného kostola a časti murív ohraničujúcich terasy kláštora.

Kamaldulský kláštor sv. Jozefa v Nitre na Zobore vznikol na mieste, kde stál až do konca 15. stor. najstarší kláštor na území Slovenska - benediktínsky Kláštor sv. Hypolita (obr. 1; 2). Po jeho opustení areál kláštora chátral, sakrálna tradícia lokality však nezanikla. K bývalému kláštoru sa vypravovali veriaci počas pravidelne konaných pútí, až napokon údajne v roku 1663 dal nitriansky biskup Juraj Pohronec Slepčiansky (Szelepcsényi) postavit na dvore benediktínskeho kláštora oktogonálnu kaplnku zasvätenú Ondrejovi a Benediktovi „v ktorej sa pontifikálne služby božie a kázeň dodržiavali" (Kompánek 1895, 111). Obnovit”

\footnotetext{
4 Jeden z nich, Pazaislis pri Kaunase, sa nachádza na území dnešnej Litvy.

5 V roku 2011 bolo vo svete ešte 10 kláštorov, z toho štyri na americkom kontinente (Kolumbia - 2, USA - 1, Venezuela - 1) a v Európe 6 (Taliansko - 3, Pol'sko - 2, Španielsko - 1; Mulitzer 2012; 2014, 16-19).
} 


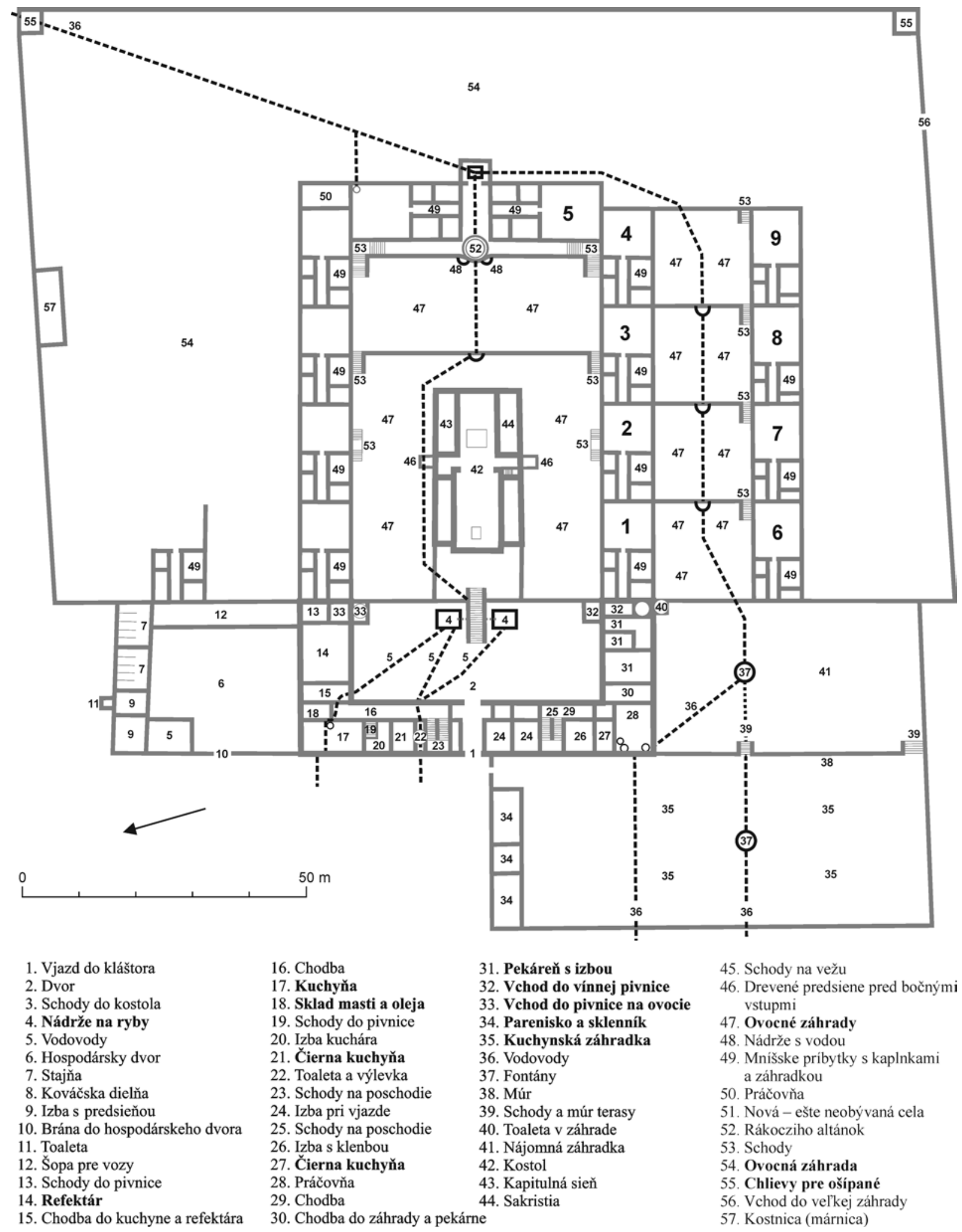

Obr. 3. Digitalizovaný plán kamaldulského kláštora sv. Jozefa v Nitre na Zobore z 18. stor. s vyznačením polohy mníšskych príbytkov 3 a 9 a funkcie jednotlivých miestností a priestorov. Tučným písmom sú označené priestory súvisiace so stravovaním a vel'kými číslami mníšske príbytky opisované v texte. Podla plánu C. Schlegela digitalizoval M. Samuel. Originál plánu uložený v Magyar Országos Levéltár Budapest, sign. S12, Div 9, No 60: 1-2. Preklad textovej prílohy k plánu R. Ragač. 
kláštorný život na Zobore sa na sklonku 17. stor. rozhodli nitriansky biskup (a súčasne hlavný župan, královský radca a kancelár), barón Blažej Jaklin z Lefantoviec a jeho bratranec, kapitán nitrianskeho hradu, barón Mikuláš Jaklin. V Nitre dňa 28. júna 1691 spísali dokument, v ktorom vyjadrili odhodlanie financovat bez časového obmedzenia v rovnakom pomere výstavbu a prevádzku kláštora pre 12 reholníkov kamaldulského rádu. Zakladatelia oznámili svoj úmysel královi Leopoldovi I., ktorý 5. septembra 1691 vo svojom odporúčajúcom liste, okrem iného, povolil využívanie dôchodkov z pilišského opátstva tak, aby „slúžili v prospech rádu, a mohlo z nich 12 reholníkov slušne žit“" (Cserenyei 1911). Po prerokovaní a odobrení projektu Generálnou kapitulou kamaldulského rádu v roku 1692 kardinál Leopold Kolonič (Kollonich) dekrétom zo dňa 14. marca 1693 úradne erigoval vznik „pustovne“ sv. Jozefa na hore Zobor (Lacko 1967, 152).

Vzhlad kláštora poznáme vd’aka niekol'kým zachovaným ikonografickým prameňom ${ }^{6}$ a doposial' realizovaným archeologickým výskumom. Z nich vyplýva, že zoborský kláštor bol pomerne rozsiahly (162 x $165 \mathrm{~m})$ areál, ktorý bol postavený na niekol'kých umelo vytvorených terasách. ${ }^{7}$ Vnútorná plocha kláštorného areálu vymedzená murovanou ohradou a budovami zaberala plochu takmer 2,3 ha. Centrálna čast̉ areálu mala symetrickú kompozíciu, v ktorej strede stál kláštorný kostol, trojlodie bazilikálneho typu s vežou vztýčenou uprostred južnej lode. Po bokoch kostola sa tiahli dve dvojité línie mníšskych príbytkov. Tretia línia domčekov stála východne od kostola na najvyššej terase kláštora. Na západnej strane sa dve vnútorné línie príbytkov napájali na bočné krídla hlavnej hospodárskej budovy konventu. Tá mala dve nadzemné podlažia a tri krídla vytvárajúce pôdorys v tvare U. Severne od tejto budovy stála menšia prízemná dvojkrídlová hospodárska stavba, d’alšie úžitkové stavby sa nachádzali pri múroch ohrady. Súčastou kláštora bola od roku 1704 aj náročná technická stavba, kamenný vodovod, ktorý privádzal do kláštora vodu z tzv. Svoradovho prameňa a distribuoval ju viacerými vetvami do miestností kláštora, práčovní, fontán a nádrží. Prebytočná voda napája dvojicu rybníkov pod kláštorom. ${ }^{8}$ Zo zachovaného plánu kláštora (obr. 3) poznáme rozmiestnenie niekol'kých objektov súvisiacich so stravovaním (refektár, kuchyne, izba kuchára) a uskladňovaním potravy (sklad masti a oleja, ovocia, vína), ale aj ich produkciou (pekáreň, zeleninové a ovocné záhrady, skleníky, pareniská, ale aj chlievy pre ošípané). Rozsiahly komplex bol pôvodne koncipovaný pre 12 reholníkov, služobníctvo a ako sme spomenuli, jeho prvý „,obyvatelia“ boli rehol'níci z Monte Corony talianskej národnosti, ktorý postupne prijali medzi seba Mad’arov, Nemcov, Slezanov, Moravanov a Slovákov. Slováci pochádzali najmä z nitrianskeho regiónu a časom tvorili takmer polovicu pustovníkov teologickej školy na Zobore (Lacko 1965).

Domčeky a záhradky mali rovnaký pôdorys a jednotnú dispozíciu pozostávajúcu zo štyroch miestností, kaplnka/modlitebňa (oratorium), hlavná obytná miestnosṫ s postelou a knižnicou (cubiculum), dielňa/pracovňa (laboratorium), komora s hygienickým kútom slúžiaca aj ako sklad dreva (camera pro conservandis lignis), oddelených ústrednou chodbou (vestibulum). Vchod pre mníchov sa otváral do záhrady (introitus ad hortulum), ktorá mala okrasný i úžitkový charakter. Trojkrídlová dvojpodlažná hlavná budova konventu v popredí so vstupnou bránou mala priečelie akcentované zvonicou s hodinami. Nad bránou zvnútra sa nachádzal nápis "Absit ab hac porta sacra turbator eremi, Odit enim turbas turba sacrata Deo"9 (Kompánek 1895, 112). Zvyšok areálu, ohraničeného plným múrom okrem menšej hospodárskej budovy, vyplňal sad a záhrady. Pred bránou kláštora sa nachádzal malý cintorín. Súčastou areálu bol aj kamenný vodovod privádzajúci sem vodu z prameňa pod jaskyňou sv. Svorada. Vodovod napájal nielen jednotlivé budovy a fontány $\mathrm{v}$ areáli, ale prebytočnou vodou zásoboval aj rybník (rybníky?) pod kláštorom (Habovštiak 1971, 117, 118). V roku 1782, po necelých 90. rokoch konvent rozpustil panovník Jozef II. V tom čase kláštor obývalo osem pátrov, pät klerikov a pät frátrov (Kompánek 1895, 114). Väčšina areálu vrátane kostola zostala opustená, len čast hospodárskych budov bola využívaná na rôzne účely (textilná manufaktúra, hostinec, klimatické kúpele, sídlo misionárov Božieho slova) až do konca 50. rokov 20. stor., ked' sa začala budovat liečebňa respiračných chorôb.

6 Najznámejšie je zobrazenie na olejomalbe ktorá bola pôvodne súčastou hlavného oltára kláštorného Kostola sv. Jozefa. V centrálnej časti výjavu je s vel'kým zmyslom pre detail zobrazená z vtáčej perspektívy podstatná čast' kláštorného areálu (obr. 2).

7 Autorom projektu bol taliansky architekt pôsobiaci vo Viedni Domenico Martinelli (Lorenz 1991, 199).

8 Š. Cserenyei v roku 1911 uvádza, že oba rybníky sú už 30 rokov zanedbávané a zanesené padajúcim lístím (Cserenyei 1911).

9 V preklade „Tejto od brány uteč, samotu kdo krikmo urážaš; Návidet sbor zvady náš nikdy nemôže lud“ (Kompánek 1895, 112), resp. „Nech je vzdialený od tejto brány rušitel’ samoty, lebo Bohu zasvätený sbor nenávidí rušitelov pokoja“ (Branecký 1945, 22).. 
Na lokalite sa uskutočnilo niekol'ko záchranných a zistovacích archeologických výskumov. Počas prvého v roku 1940 sa okrem malej časti stredovekého kláštora odkryla aj dvojica barokových mníšskych príbytkov (Kraskovská 1942-1943). Žial', dokumentácia a nálezy z tohto výskumu zhoreli počas bombardovania Bratislavy na sklonku 2. svetovej vojny a krátky informačný článok o výsledkoch výskumu nespomína žiadne nálezy súvisiace s problematikou stravovania mníchov. Tejto problematike nevenoval pozornost̉ ani nasledujúci záchranný výskum v rokoch 1960-1961 (Habovštiak 1966; 1971). ${ }^{10}$

Až v rokoch 2001-2003, 2006, 2008 a 2016 sa uskutočnilo niekol'ko (väčšinou kratších) zistovacích a záchranných výskumov. Vtedy bolo možné systematickejšie preskúmať čast’ areálu bývalých kláštorov, hlavne priestor južne od ruiny kostola sv. Jozefa (súhrnne Samuel 2010; 2011; Samuel/Tirpák 2012). V tomto priestore sa čiastočne odkryli zvyšky troch mníšskych príbytkov, z pohladu riešenej problematiky boli dôležité hlavne nálezy z príbytkov 3 a 9 (obr. 5; Samuel, v tlači). Podstatná čast̉ hodnoteného materiálu $(82,5 \%)$ pochádza z príbytku 9 a jeho hospodárskej miestnosti (vzorka 12). Miestnosł́ slúžiaca ako sklad dreva a zrejme aj toaleta bola rozdelená na dve časti. Menšiu čast’ vytváral zahĺbený, pôvodne zaklenutý murovaný priestor s vetracou (?) šachtou a hlinenou podlahou. Mohlo íst’ o menšiu pivnicu, resp. odpadovú šachtu (žumpu?) toalety. V zásype priestoru sa našlo vel'ké množstvo archeologického materiálu, vrátane súboru keramických a sklenených nádob, dobre reprezentujúceho sortiment predmetov súvisiacich so stolovaním a stravovaním.

\section{Štýl života a spôsob stravovania}

Kamaldulská kongregácia dnes zastrešuje tri komunity v Taliansku, dve v Pol’sku a jednu v Španielsku, Spojených štátoch, Kolumbii a Venezuele. ${ }^{11}$ Kláštory fungujú na princípe pustovní a sú zakladané na samote, mimo obývaných miest. O štýle života v jednej z nich, v pol'ských Bielanoch pri Krakove, priniesol nedávno svedectvo F. Mikloško (2012). Opisuje izoláciu komunity od okolitého sveta a uvádza, že prísnejšiu reholu majú už len trapisti, ktorí sa nesmú rozprávat’ ani obkolesovat' zeleňou. Kamalduli naopak zeleň milujú. Pustovňa v Bielanoch leží na kopci pri Krakove a funguje bez prerušenia od roku 1609. Uprostred areálu stojí kostol a dalšie spoločné budovy ako kapitula, knižnica, kuchyňa a jedáleň, ktorá slúži na významné sviatky. V klauzúre sú pozdíž chodníka pravidelne rozostavené jednoduché domčeky reholníkov so záhradkami ohradené múrom. Domčeky majú podobnú vnútornú dispozíciu ako na Zobore (pozri vyššie). Ich zariadenie je strohé, rehol'níci spia na drevenej posteli so slamníkom. Každý domček obýva jediný brat alebo otec odetý v bielom rúchu s vyholenou hlavou, dlhou bradou a fúzami. Jednoduchú a zvyčajne vegetariánsku stravu im roznáša kuchár v obedároch. Jedia osamote. Na raňajky majú čiernu meltovú kávu a chlieb, na obed zeleninovú polievku, zemiak, kúsok ryby alebo vajce, na večeru zemiakovú kašu s kyslým mliekom alebo boršč. Nakupujú iba chlieb, mlieko a ryby. Väčšinu času trávia v samote a venujú sa modlitbe a štúdiu. Do kostola prichádzajú na spoločné bohoslužby. Okrem intelektuálnej činnosti majú povinnost’ pracovat pre úžitok kláštora a spolubratov (obr. 4). Slúžia v kuchyni, záhrade alebo sa venujú drobným opravám, či návštevám. Prichádzajú sem ludia, ktorí chcú trávił istý čas osamote - kňazi, maliari, mladí muži so záujmom o mnišsky spôsob života. $\mathrm{V}$ jednom z domčekov žije mních odlúčený od sveta už 20 rokov a o jeho existencii svedčia len prázdne obedáre medzi dverami.

V minulosti mal eremitizmus mnohoraké formy (Pomfyová 2015, 299-303). Pustovníci žili bud' jednotlivo, alebo v skupinách, v úplnej odlúčenosti alebo vo väzbe na kláštor, či kostol, na odlahlých miestach aj uprostred miest. Niektorí predstavovali potulných askétov a misionárov, ktorí chodili medzi veriacich ako kazatelia, či ošetrovatelia. Iní pustovňu neopúštali a venovali sa iba kontemplácii a odriekaniu v uzavretých celách, tzv. inklúzi/reklúzi (Pomfyová 2015, 299). Archívne pramene svedčia o uplatňovaní tohto asketického štýlu života i v Zoborskom kláštore. V roku 1726 tu napríklad frátrovi Kajetánovi generálna kapitula poskytla opätovné povolenia k reklúzii na viac ako 14 rokov (Lacko 1965, 108, 109). Toto privilégium dostali viacerí, no dodržat disciplínu nebolo jednoduché. Napríklad frátrovi Henrymu bola reklúzia po roku zrušená s odôvodnením porušovania pravidiel v styku s ostatnými bratmi (Lacko 1965, 109). Listiny svedčia tiež o tom, že kamalduli zo Zobora kombinovali pustovnícky štýl života s cenobitizmom. Zdá sa, že najmä náboženské interakcie s okolím boli intenzívne (Lacko 1965; Vozár 1997). Okrem

\footnotetext{
10 Výskum sa uskutočnil počas výstavby liečebne a bol priestorovo limitovaný na dokumentáciu niekol'kých kanalizačných rýh a dokumentáciu barokového vodovodu mimo plochy staveniska. Rozsiahle plochy pod budovami liečebne neboli skúmané.

11 https://www.camaldolese.org
} 

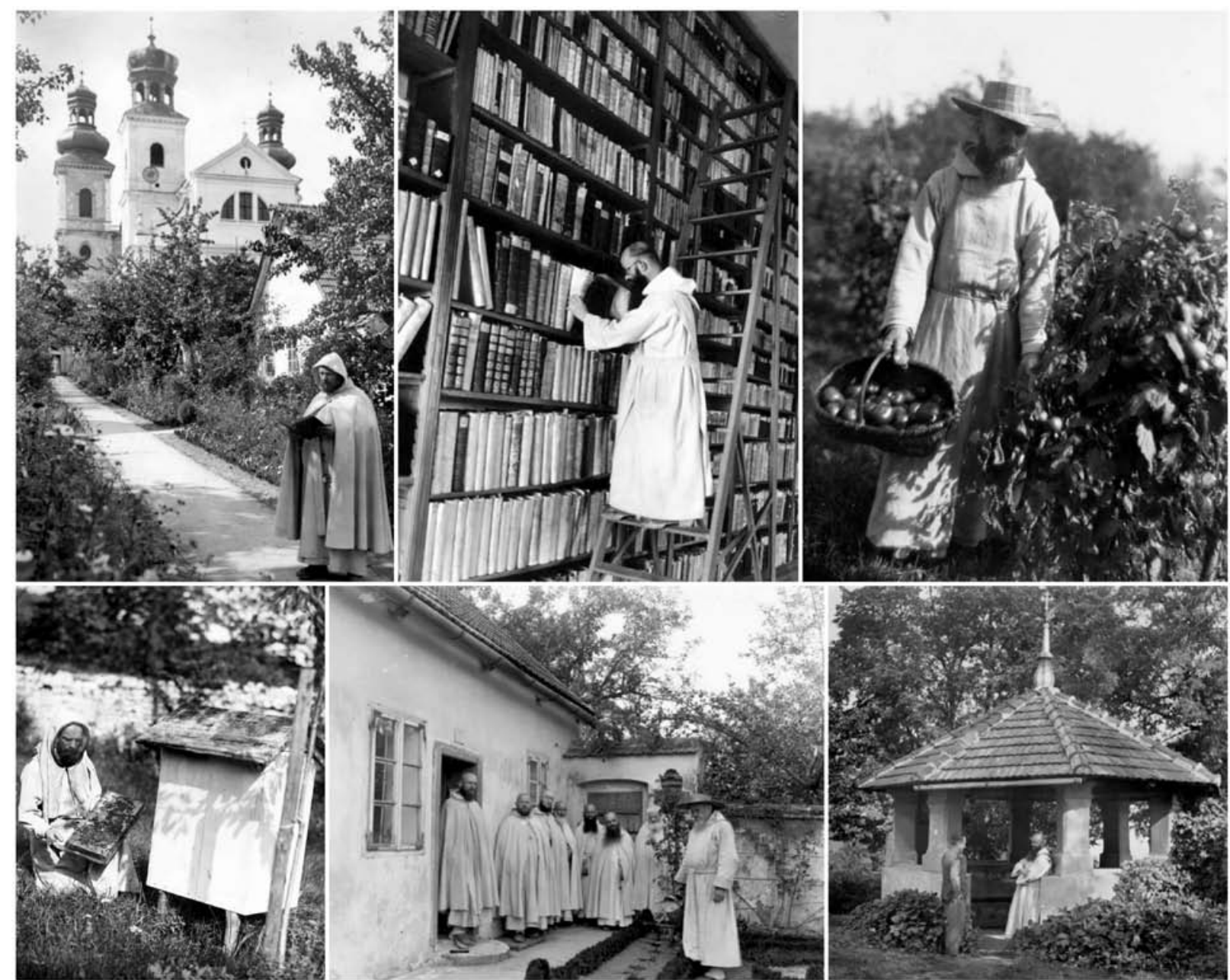

Obr. 4. Zo života kamaldulských mníchov v Bielanoch (Pol’sko). Archívne fotografie z roku 1930 a 1934. Zdroj: www. http://krakow.naszemiasto.pl/artykul/klasztor-na-bielanach-przed-wojna-zdjecia,3157653,artgal, t,id, tm.html (upravené).

toho, že spolupracovali s inými pustovňami rádu v Uhorsku, napr. s lechnickou na preklade Biblie do slovenčiny, často sa objavujú aj ako referujúci v správach o kandidátoch na biskupský stolec v Nitre (Judák 1997, 79, 80). Nitrianski biskupi vysluhovali členom rehole posvätné rády, no viedli s kláštorom i spory, napr. o užívaní lesov (Judák 1997; Vozár 1997, 87). Zdá sa, že niektorí zoborskí mnísi pomerne často cestovali (napr. do Viedne), čo vzbudilo nevôlu generálnej kapituly, kedže nocovali v svetských domoch (Lacko 1965, 107, 108). Kritizovali Zoborský kláštor aj za to, že nakupujú drahé látky z dovozu na ošatenie mníchov, že sa v rámci návštev objavujú v klauzúre ženy a že sa v kláštore konajú nestriedme oslavy spojené s celodennými debatami a dobrým „pôstnym (?)“ jedlom. Čo sa týka stravovania kamalduli, podobne ako väčšina rehol’níkov všetkých krestanských kongregácií mali a dodnes majú prísne pravidlá týkajúce sa tejto stránky ich života. Všeobecne akceptovaná striedmost̉ v prijímaní potravy bola zakotvená $\mathrm{v}$ ich Regule, ktorá vychádzala zo zásad zostavených už sv. Benediktom na sklonku jeho života († 547) v kláštore Montecassino. Základným obmedzením v zložení stravy bol zákaz konzumácie mäsa štvornohých zvierat. Za mäsitú stravu sa však nepovažovalo jedlo z rýb a iných druhov viazaných na vodné prostredie (napr. bobor, vydra, korytnačka, rak). Súčastou stravovacieho „kalendára“ boli pravidelné pôsty vykonávané jednak v rámci cirkevného roka, ale aj počas dní bežného týždňa. „Milovat’ pôst" bol jeden zo spôsobov uskutočňovania dobrých skutkov. V kapitole Benediktovej regule „O miere jedla“ sa píše: „Dve varené jedlá musia stačit všetkým bratom, keby bolo ovocie alebo mladá zelenina, môže sa dat ako tretie“. Denná dávka chleba bola stanovená na maximálne jednu libru (v tom čase okolo $330 \mathrm{~g})$, vína dostal mních denne jednu heminu (1/2 litra ?). V prípade namáhavejšej práce mohol opát zvýšit objem stravy „ale tak, aby sa vždy vyhlo nemiernosti“, pretože „nič nie je pre krestana také nevhodné 


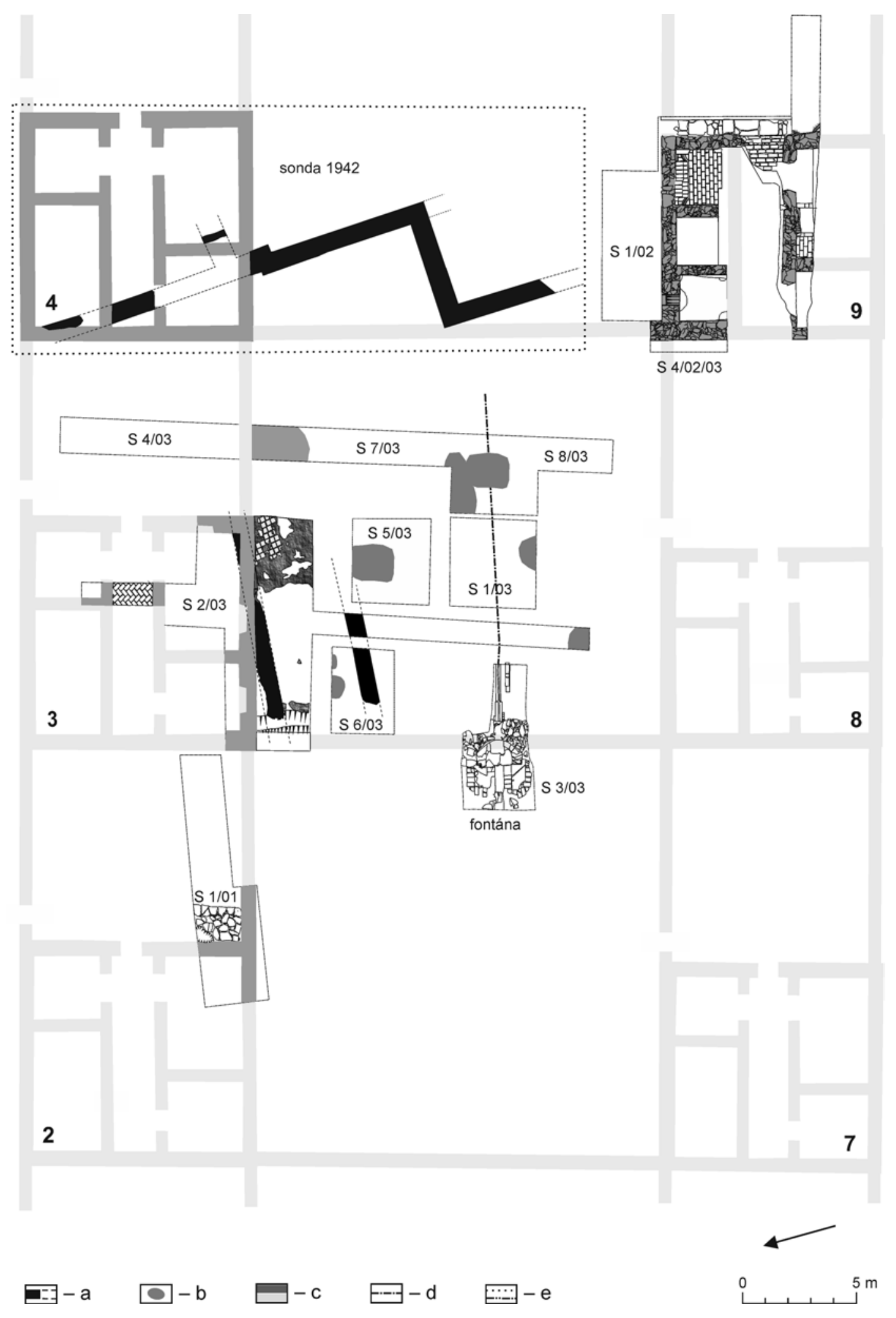

Obr. 5. Plán preskúmaných plôch južnej línie mníšskych príbytkov z výskumov v rokoch 1942 a 2001-2003: a - odkryté stredoveké murivá benediktínskeho kláštora sv. Hypolita a ich predpokladaný priebeh; b - stredoveké objekty; c-odkrytý/predpokladaný priebeh murív kamaldulského kláštora sv. Jozefa; d - kamenný barokový vodovod s fontánou; e - hranice skúmaných plôch v roku 1942 a v rokoch 2001-2003. Plán M. Samuel. 
Tabela 1. Nitra-Zoborský kláštor. Súpis analyzovaných vzoriek z roku 2003.

\begin{tabular}{|c|c|c|c|c|c|c|}
\hline Vzorka číslo & Sonda & Sektor & Híbka (cm) & Datovanie & Kontext & Počet nálezov \\
\hline 1 & $2 / 03$ & A & $150-160$ & novovek & pás čiernej hliny pred južnou stenou eremitky 3 & 278 \\
\hline 2 & $2 / 03$ & $\mathrm{D}$ & $110-115$ & novovek & sut' tesne nad podlahou eremitky 3 & 355 \\
\hline 3 & $2 / 03$ & C & $145-155$ & novovek & čierna hlina pod staršou podlahou eremitky 3 & 32 \\
\hline 4 & $2 / 03$ & $\mathrm{D}$ & $145-155$ & novovek & tmavá hlina pod staršou podlahou ermitky 3 & 62 \\
\hline 5 & $2 / 03$ & $\mathrm{D}$ & $155-165$ & novovek & svetlohnedá hlina (navážka) & 97 \\
\hline $6+8$ & $5 / 03$ & - & $80-85$ & novovek (?) & žlto-hnedá hlina s kameňmi, maltou a mazanicou & 47 \\
\hline 7 & $6 / 03$ & - & do 85 & novovek (?) & $\begin{array}{l}\text { začistenie pôdorysu, maltovo-hlinitá vrstva nad murivom } \\
\text { benediktínskeho kláštora }\end{array}$ & 13 \\
\hline 9 & $4 / 02 / 03$ & - & $40-80$ & po 1782 & prehíbenie západného okraja sondy (exteriér eremitky 9) & 3 \\
\hline 10 & $6 / 03$ & - & $90-105$ & stredovek (?) & $\begin{array}{l}\text { rozoberanie vrstvy bielej malty s hlinou nad murivom } \\
\text { benediktínskeho kláštora }\end{array}$ & 6 \\
\hline 11 & $5 / 03$ & - & $105-150$ & stredovek & vyberanie tmavej výplne objektu (jamy), čierno-žltá hlina & 20 \\
\hline 12 & $4 / 02 / 03$ & - & $275-285$ & 2. pol. 18. stor. & 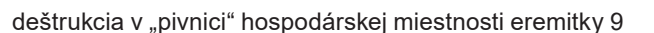 & 4288 \\
\hline
\end{tabular}

ako prejedanie“. Starým alebo chorým bratom mohol predstavený kláštora povolit aj konzumáciu mäsa. Tieto a d’alšie prísne pravidlá zostavené zakladatelom rehole zostávali síce celé stáročia v platnosti, ale v reálnom živote sa nie vždy dodržiavali. ${ }^{12} \mathrm{~V}$ tejto súvislosti je tiež zaujímavá listina z roku 1765 svedčiaca o závažnom porušovaní stravovacích predpisov v Červenom kláštore, podla ktorej prior pustovne povolil mníchom konzumáciu mäsa z dôvodu lokálneho nedostatku rýb (Lacko 1965, 108, 194).

Kedže kamalduli sa nevenovali pastoračnej činnosti a nepatrili ani medzi tzv. žobravé rády, ich ekonomické jestvovanie bolo zabezpečené hlavne prostredníctvom finančných, ale aj hmotných darov. Zoborský kamaldulský kláštor nevlastnil vel'ké majetky - jeden dom v Nitre, polia v nitrianskom a žabokreckom chotári, lúky a vinice v drážovskom a oponickom chotári (Kompánek 1895, 113). Barón Mikuláš Jaklin a manželka Judita Gellért darovali kláštoru v roku 1695 majetok v Dolných Lefantovciach vo výške 10 tisíc zlatých spolu s kaštielom. Mnísi z toho mali dostávat' ročne úroky vo výške 600 zlatých na živobytie (Vozár 1997). Na chod kláštora postupne prispievali viacerí dobrodinci bud’ jednorazovo, alebo základinami na odslúženie sv. omší (Judák 1997; Lombardini 1895). Sú medzi nimi občania Nitry a okolia. Napríklad gróf Lazar Appony zložil fundáciu na zriadenie rodinnej hrobky pri kostole sv. Jozefa, reholnícky novic Baltazár Podhoranyi prispel na ohradenie pustovne, nitriansky kanonik Franko Vadász zložil peniaze na udržiavanie pre seba vystavaného pustovníckeho domčeka, alebo Michal Botka, ktorý u zoborských pustovníkov jedával, na slúženie sv. omší (Lombardini 1895, 123). V dokumentoch, ktoré uchovávajú v Mad’arsku sa objavujú aj mená prokurátorov, ktorí mali na starosti hospodárske záležitosti kláštora (Vozár 1997).

\section{MATERIÁL A METÓDY}

\section{Archeologický kontext a datovanie nálezov}

Súbor archeozoologických zvyškov z výskumu v roku 2003 tvorí 5201 položiek s celkovou hmotnostou 2,8 kg. Materiál zahŕňa kosti/zuby stavovcov, fragmenty vonkajšieho panciera (exoskeletonu) kôrovcov a škrupiny (vtáčích) vajec. Zvyšky sú vo výbornom stave, s neporušenou povrchovou štruktúrou kostí, bez tuhých povlakov a erózie. Modifikácie materiálu sú najmä antropogénneho pôvodu, to znamená, že zvyšky boli akumulované na lokalite v dôsledku činnosti človeka. Stupeň rozrušenia celistvosti kostí je nízky až stredný, spôsobený prevažne luudskými zásahmi v procese mäsiarskej/kuchynskej úpravy a konzumácie mäsa a kostí človekom, príp. zvieratami. Na lokalite nebol odkrytý žiaden kompletný či

12 Napr. budínska synoda v roku 1227, sa konzumáciu mäsa ani nepokúšala zakázat', len ju obmedzila na predvianočný a predvel'konočný pôst (Regula sv. Benedikta 2010). 

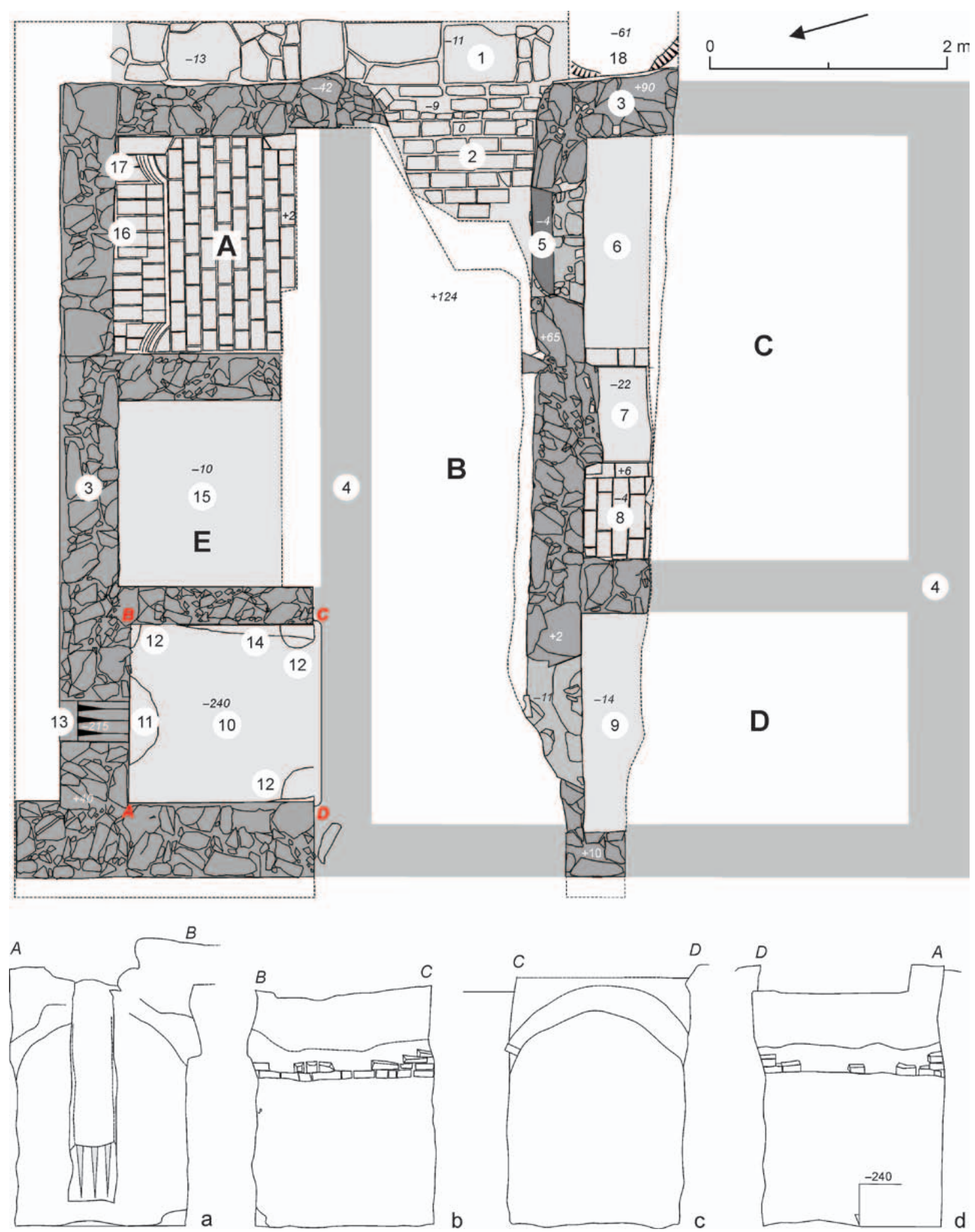

Obr. 6. Pôdorys mníšskeho príbytku 9 a profily „pivnice“: A - kaplnka; B - chodba; C - hlavná obytná miestnost;; $\mathrm{D}$ - pracovňa; E - hospodárska miestnost' s „pivničným“ priestorom; 1 - exteriérová kamenná dlažba; 2 - tehlová podlaha chodby; 3 - kamenné nadzákladové murivo; 4 - predpokladaný priebeh murív mníšskeho príbytku; 5 - drevená doska prahu; 6 - nekompaktné zvyšky tehlovej podlahy; 7 - tehlový sokel vykurovacieho zariadenia; 8 - tehlová podlaha; 9 - nekompaktná maltová podlaha; 10 - hlinitá podlaha „pivnice“; 11 - maltový jazyk; 12 - kolové jamky; 13 - vetracia šachta; 14 - zvyšky tehlovej klenby; 15 - maltová podlaha; 16 - tehlový sokel oltára; 17 - profilovaná rímsa sokla oltára; 18 - jama (stredovek?). Plán M. Samuel. 


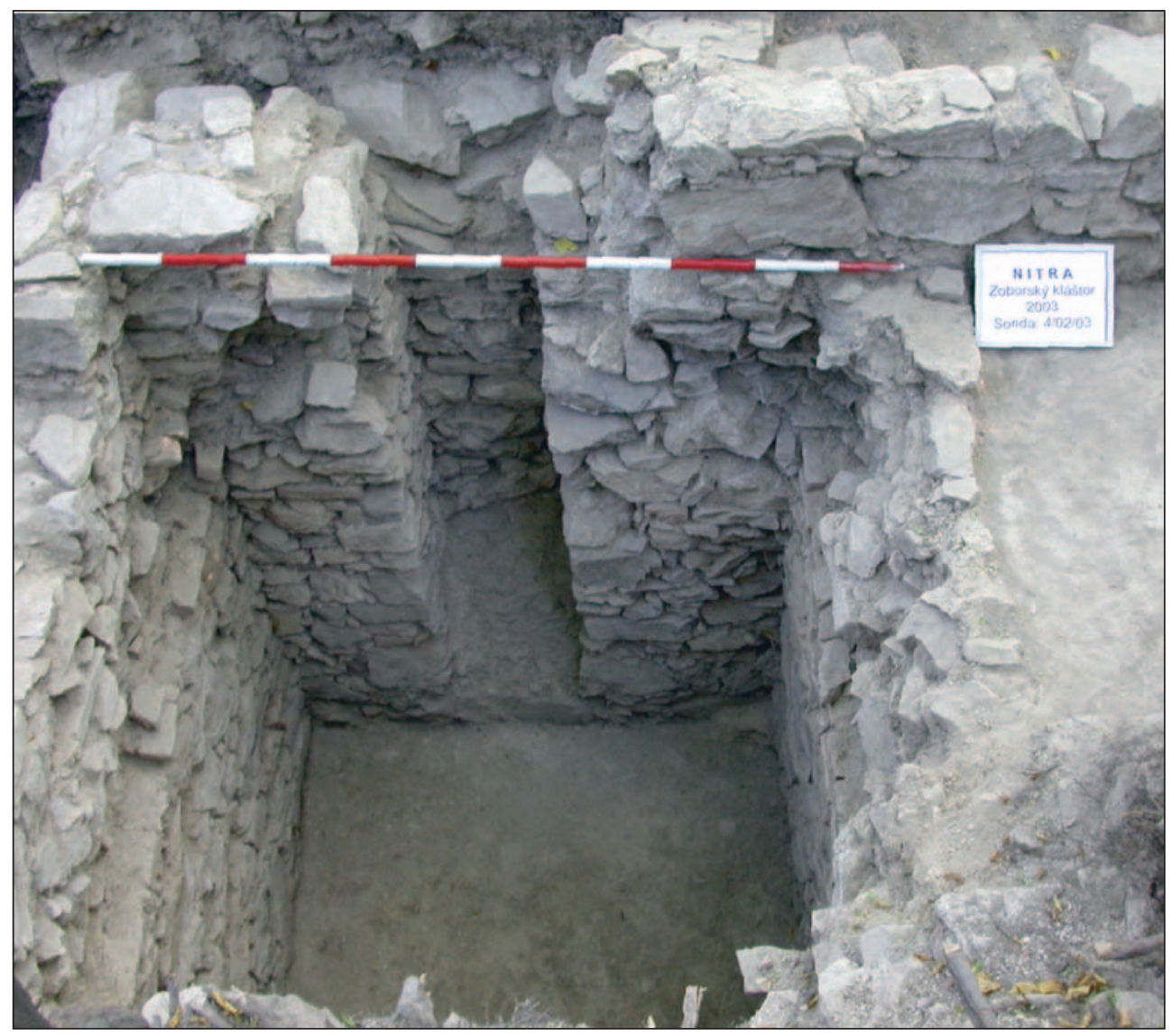

Obr. 7. Pohl’ad z juhu na „pivničný“ priestor hospodárskej miestnosti mníšskeho príbytku 9. Foto M. Samuel.

čiastočne artikulovaný skelet zvierata. Súbor pochádza z 12 kontextov (vzoriek 1-12) zo štyroch sond skúmaných v roku 2003 (obr. 5).

Zo sondy 2/03 pochádza 15,8 \% z celkového počtu nálezov (tabela 1). Pokrýva areál mníšskeho príbytku 3 a čast' jeho exteriéru. Ide o najlepšie zachovaný mníšsky príbytok kláštora. Jeho nadzemné murivá príbytku sú zachované miestami až do výšky $1 \mathrm{~m}$ a západná aj severná obvodová stena, tvoriaca súčast barokovej terasy, dokonca do výšky 2-3 m. Domček mal pôdorys $9 \times 10 \mathrm{~m}$ a podobne ako v iných kláštoroch pozostával zo štyroch miestností rozdelených chodbou. Najväčšia miestnost̉ bola prístupná z chodby dverným otvorom so zošikmenými špaletami situovanými na lavej strane od vstupu a slúžila ako hlavná obytná miestnost'. Zachoval sa v nej tehlový sokel vykurovacieho telesa $\mathrm{s}$ otvorom na prikladanie, umiestneným na chodbe. Menšia miestnost’ s takmer štvorcovým pôdorysom za hlavnou obytnou miestnostou slúžila zrejme ako pracovňa. Bola prístupná dverným otvorom z chodby vydláždenej tehlami. Miestnost napravo od vstupu, kaplnka, mala štvorcový pôdorys a maltovú podlahu. Štvrtá miestnost' domčeka slúžila ako hospodárska miestnost', resp. sklad s toaletou. Z roku 2003 pochádzajú vzorky $2-5$ z výskumu dvoch južných miestností (hlavná obytná miestnost’ a pracovňa) a $\mathrm{k}$ nim prilahlej časti spojovacej chodby. Našli sa v rôznej híbke vo vrstvách tesne nad podlahami a pri ich rozoberaní alebo vo vrstvách pod nimi. Vzorka 1 pochádza z exteriéru domčeka z vrstvy čiernej hliny vytvárajúcej pás prebiehajúci pred jeho južnou fasádou. Pás hliny mal v profile tvar plytkého žlabu. Je zrejmé, že žlab vznikol v súvislosti s výstavbou príbytku a mohol slúžit na odvádzanie daždovej vody. V priebehu existencie kláštora sa postupne vypíňal splavenou hlinou obsahujúcou aj zvyšky stravy. Všetky spomínané kontexty teda vznikli v súvislosti s výstavbou kláštora, jeho existenciou a obdobím tesne po jeho opustení. Taktiež sortiment živočíšnych druhov (morka domáca, sladkovodné korytnačky, ryby, viac v kapitole Výsledky a diskusia) zachytený vo vzorkách vzorke 1, 2 a 4 svedčí novovekom pôvode a zastúpení kláštorného aj laického prostredia (doložená prítomnostou bežných hospodárskych druhov). 
Prevažná väčšina hodnotených nálezov ( $82,5 \%$ ) pochádza zo sondy 4/02/03. Tá pokrývala interiéry a menšej miere exteriéry mníšskeho príbytku 9 (obr. 6). Polohu domčeka pred zahájením výskumu naznačovalo návršie mohylové tvaru prečnievajúce vyše $1 \mathrm{~m}$ nad okolitý terén. Návršie s porastom niekol'kých stromov pozostávalo z deštrukcie mníšskeho príbytku premiešanej s lesnou hlinou. Príbytok sa skúmal v smere od vstupu do domčeka. Pred vstupom sa odkryl chodník prebiehajúci pozdĺž východnej fasády domčeka. Chodník vytvárali rôzne vel'ké lomové kamene miestnej proveniencie ukladané na plocho. Postupne sme odkryli dverný otvor, obvodové steny eremitky, krátky úsek chodby s tehlovou dlážkou, neskôr severnú čast' hlavnej obytnej miestnosti s tehlovým soklom vykurovacieho telesa a oproti vstupu do tejto miestnosti privátnu kaplnku s tehlovou dlážkou a tehlovým soklom oltára. Steny príbytku sa zachovali max. do výšky $40 \mathrm{~cm}$. Posledným preskúmaným priestorom bola hospodárska miestnost' (obr. 7). Ukázalo sa, že je členená na dve nerovnako vel'ké časti. Väčšia čast’ mala rozpadnutú maltovú podlahu a $\mathrm{v}$ druhej časti sa nachádzal zahíbený murovaný priestor hlboký $240 \mathrm{~cm}$ (od úrovne podlahy v chodba) so zretelnými stopami po valenej klenbe. $\mathrm{V}$ osi severnej steny sa nachádzal zvislý ústupok v murive pripomínajúci vetraciu šachtu, dno vytvárala ušlapaná hlina. Funkcia tohto priestoru nie je jednoznačná. Mohlo íst’ o malú pivnicu alebo priestor pod toaletou, ktorá sa podla zachovaných plánov v tejto časti domčeka nachádzala. Zásyp „pivnice“ až do híbky 15-30 cm nad jej dnom vytvárali kamene z deštruovaných stien príbytku, premiešané s hrudkami malty, pieskom a lesnou hlinou. Najspodnejšiu čast’ priestoru vypĺňal takmer výlučne jemnozrnný zásyp (sediment). Počas vyberania kamenistej časti zásypu sa našiel iba malý počet archeologických a archeozoologických nálezov. Jemnejší sediment, ktorý bol pôvodne vápenno-pieskovou maltou sa preosieval a detailne prezeral. Drvivá väčšina získaného keramického, skleného a osteologického materiálu (vzorka 12) pochádza zo spomínanej jemnozrnnej vrstvy nad dnom objektu. ${ }^{13}$ Unikátny je súbor keramických a sklenených nádob dobre reprezentujúceho sortiment predmetov súvisiacich so stolovaním a stravovaním kamaldulských mníchov. Na základe odhadu životnosti keramiky, letopočtov na dvojici fajansových šálkach $(1760,1765)$ a historických faktov o rozpustení kláštoru (1782), bolo možné stanovit dobu používania objavených predmetov do posledných dvoch až troch decénií existencie kamaldulského kláštora (Samuel/Čurný 2010, 269). Podobne je možné datovat aj sprievodný archeofaunálny materiál. Výskum príbytku sme ukončili rozšírením sondy o malú plochu pred jeho západnou stenou, kde sa našlo niekol'ko kostí zvierat (vzorka 9). Tie však už zrejme nesúvisia s existenciou kamaldulského kláštora, ale reprezentujú horizont jeho pustnutia, resp. využívania na iné účely.

Vyhodnotený archeozoologický súbor dopĺňajú minimálnou mierou (1,7 \%) vzorky zo sondy 5/03 a 6/03. Pochádzajú z priestorov medzi radmi príbytkov, kde sa zachovali stredoveké kontexty. Zatial' čo vzorka 11 pochádza z výplne stredovekého objektu, vzorky 7 a 10 môžu súvisiet s obdobím zániku a pustnutia kláštora na sklonku stredoveku.

\section{Metódy archeozoologického výskumu}

Zvyškom zvierat bola venovaná počas archeologického výskumu náležitá pozornost', a to aj vd’aka zanietenému prístupu študentov archeológie, ktorí na výskume v roku 2003 participovali. Sediment dôsledne preosievali a vyberali i najmenšie, okom rozpoznatel'né fragmenty. Celý objem zásypu pivnice z príbytku 9, až na jej malú čast', bol nasucho preosiaty cez sitá s priemerom oka asi $5 \mathrm{~mm} .{ }^{14}$ Archeológovia konzultovali po odbere vzoriek postup čistenia materiálu s osteológom.

Hned' po ukončení exkavácie sa kosti premývali v laboratóriu, v sitách s vel'kostou oka 1-2 mm. V d’alšej časovo náročnej fáze laboratórneho spracovania sa kosti predbežne triedili na základe anatomickej a taxonomickej príslušnosti a uskladnili do vreciek s informáciou o kontexte. Základná analýza sa uskutočnila v roku 2017 a k vyhodnoteniu výsledkov autori pristúpili nasledujúci rok. Na taxonomickej a anatomickej identifikácii sa podielali viacerí autori, K. Hensel (ryby), Z. Bielichová (cicavce, vtáky) a R. Kyselý (morka, plch). Treba zdôraznit', že druhové určenie rýb bolo limitované rozsahom dostupnej porovnávacej zbierky a preto nemožno vylúčit, že zaznamenaný sortiment bude v budúcnosti rozšírený. Primárne dáta boli registrované v MS Access archeozoologickej databáze AÚ SAV v Nitre a pre každý fragment zahŕňajú informácie o taxonómii, anatómii, veku, pohlaví,

\footnotetext{
13 Z celkového objemu vrstvy sa preosiala väčšia čast', no jej čast’ s objemom 1-2 fúriky bola len ručne prebraná.

14 M. Čurný, ústna informácia.
} 
metrických znakoch a modifikáciách kosti (podla Lyman 1994; Reitz/Wing 1999; Schmid 1972; Silver 1969; Uerpmann 1973; Wheeler/Jones 1989). Kvantifikačné výsledky sú prezentované na základe počtu fragmentov (n), počtu identifikovaných fragmentov (NISP), hmotnosti (w), hmotnosti identifikovaných fragmentov (WISP) a minimálneho počtu jedincov (MNI). Použitá zoologická a anatomická terminológia sa pridŕža štandardov (Gentry/Clutton-Brock/Groves 2004; Lepiksaar 1983). Osteometrické dáta boli odoberané podla štandardizovaných metodík (Bocheński/Campbell 2006; Driesch 1976; Morales/Rosenlund 1979; Radu 2003). Dížka a hmotnost̉ rýb bola vypočítaná na základe koeficientov uvedených vo viacerých prácach (Bartosiewicz 1990; Brikhuizen 1989; Libois/Hallet-Libois 1988; Radu 2003). Zastúpenie skeletových elementov cicavcov z hladiska kvality svaloviny sa riadi odporúčaniami práce H.-P. Uerpmanna (1973).

\section{VÝSLEDKY A DISKUSIA}

\section{Základná taxonomická charakteristika súboru}

Asi polovicu nálezov sa podarilo zaradit do jednej z taxonomických kategórií ( $\mathrm{n}=2421=46,5 \%$ ). V súbore sú zastúpené ulitníky (Gastropoda), kôrovce (Crustacea), ryby (Osteichthyes), plazy (Reptilia), vtáky (Aves) a cicavce (Mammalia). Doposial' bolo identifikovaných 20 živočíšnych druhov, pričom pomer domácich a divých zvierat je $8: 12$ (tabela 2). Súbor je charakteristický vysokým zastúpením divo žijúcich zvierat ( $\mathrm{n}=94,2 \%$; $\mathrm{w}=50,8 \%$ ), čím sa výrazne odlišuje od doposial preskúmaných novovekých lokalít z územia Slovenska (Bielich/Bielichová/Šimkovic 2018; Miklíková 2007; Miklíková/Fabiš 2004; Repka/Sater/Šimunková 2017; Šimunková/Beljak Pažinová 2017; Vozák 2014; Vozák/Bielich, v tlači).

V rámci nitrianskeho mikroregiónu je možné porovnat nálezy zvyškov zvierat z odlišného sociálneho a archeologického kontextu. Chronologicky sú však súčasné. Z intravilánu mesta Nitry je vyhodnotených niekol'ko odpadových jám zo 16.-19. stor., v polohe Mestská tržnica (n = 745; Miklíková/Fabiš 2004) a Mostná ulica (bez kvantifikácie; Miklíková 2007). Ďalšie dáta pochádzajú z dvoch hradov situovaných na protilahlých výbežkoch pohoria Tribeč, vzdialených od kláštora približne $12 \mathrm{~km}$. Ide o materiál z hradov Gýmeš a Oponice. Prvý súbor obsahuje materiál zo zásypu ruín gotickej brány, vstupu do pivnice hospodárskej budovy a bočného parkánového vstupu $(\mathrm{n}=801$; Vozák/Bielich, $v$ tlači), druhý predstavuje nálezy z interiéru útočnej veže, z nárožia paláca a úsekov hradbového múru aj hradného nádvoria ( $\mathrm{n}=296$; Repka/Sater/Šimunková 2017). Oba reprezentujú odpad zo 16.-18. stor. Porovnanie zastúpenia živočíšnych druhov poukazuje na podobnost’ mesta a okolitých hradov, no najmä na špecifický sortiment kláštora (obr. 8). Podiel divých druhov je velmi nízky na oboch mestských polohách (1 \% NISP) i hradoch (3,5\%). V kláštore naopak tieto druhy jasne dominujú $(97,4 \%)$. Pozorované rozdiely v sortimente diviny najskôr reflektujú špecifiká
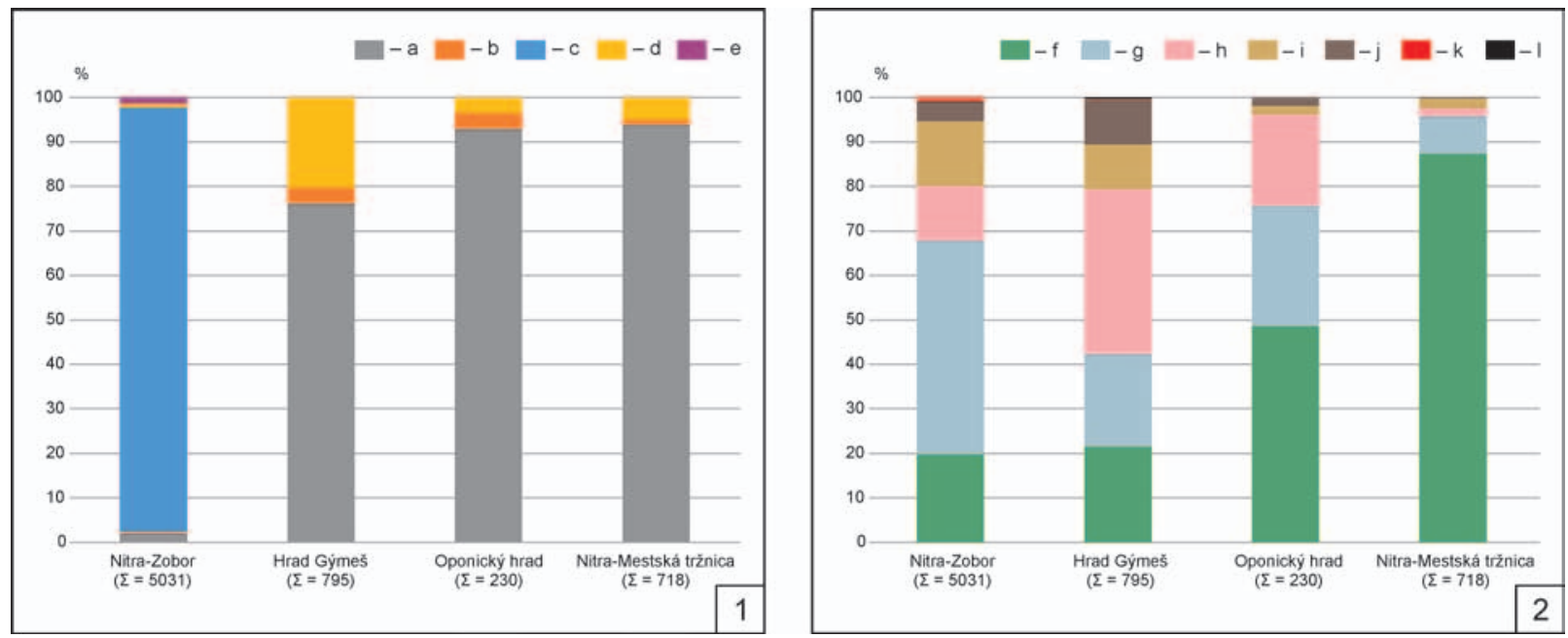

Obr. 8. Zastúpenie taxónov (\% NISP) v materiáli zo Zoborského kláštora a na ostatných novovekých lokalitách z regiónu Nitry. 1 - celý sortiment; 2 - domáce druhy. Legenda: a - domáci cicavec; b - divý cicavec; c - ryba; d - vtáky; e - korytnačka/rak; f - tur; g - ovca/koza; h - sviňa; i - kura; j - hus/kačica; k - morka; 1 - holub. 
Tabela. 2. Nitra-Zoborský kláštor. Sortiment a celkové zastúpenie živočíšnych taxónov v súbore.

\begin{tabular}{|c|c|c|c|c|c|c|c|c|}
\hline \multicolumn{2}{|c|}{ Taxón } & \multirow{2}{*}{$\frac{\text { Počet }}{n}$} & \multicolumn{2}{|c|}{$\begin{array}{l}\text { Relatívny počet } \\
\text { nálezov }\end{array}$} & \multirow{2}{*}{$\begin{array}{c}\text { Hmotnost' } \\
\text { w }\end{array}$} & \multicolumn{2}{|c|}{$\begin{array}{l}\text { Relatívna hmotnost' } \\
\text { nálezov }\end{array}$} & \multirow{2}{*}{$\begin{array}{c}\begin{array}{c}\text { Počet } \\
\text { jedincov }\end{array} \\
\mathrm{MNI}\end{array}$} \\
\hline & & & $\% \mathrm{n}$ & $\%$ NISP & & $\% w$ & $\%$ WISP & \\
\hline Domáce cicavce & Mammalia & & & & & & & \\
\hline Tur domáci & Bos taurus & 26 & 0,5 & 1,1 & 522,9 & 10,1 & 28,4 & 6 \\
\hline Ovca domáca & Ovis aries & 9 & 0,2 & 0,4 & 61,4 & 1,2 & 3,3 & 2 \\
\hline Ovca/koza & Ovis/Capra & 54 & 1,0 & 2,2 & 220,7 & 4,2 & 12,0 & 14 \\
\hline Sviňa domáca & Sus domesticus & 15 & 0,3 & 0,6 & 125,0 & 2,4 & 6,8 & 8 \\
\hline Sviňa domáca? & Sus cf. domesticus & 1 & 0,0 & 0,0 & 8,6 & 0,2 & 0,5 & 1 \\
\hline Pes domáci & Canis familiaris & 2 & 0,0 & 0,1 & 6,7 & 0,1 & 0,4 & 1 \\
\hline Kôň domáci & Equus caballus & 1 & 0,0 & 0,0 & 45,4 & 0,9 & 2,5 & 1 \\
\hline SPOLU & & 108 & 2,1 & 4,5 & 990,7 & 19,0 & 53,7 & 33 \\
\hline Divé cicavce & Mammalia & & & & & & & \\
\hline Vydra riečna & Lutra lutra & 7 & 0,1 & 0,3 & 14,9 & 0,3 & 0,8 & 2 \\
\hline Bobor eurázijský & Castor fiber & 2 & 0,0 & 0,1 & 7,4 & 0,1 & 0,4 & 1 \\
\hline Plch sivý & Glis glis & 3 & 0,1 & 0,1 & 0,4 & 0,0 & 0,0 & 1 \\
\hline SPOLU & & 12 & 0,2 & 0,5 & 22,7 & 0,4 & 1,2 & 4 \\
\hline Neurčené cicavce & Mammalia indet. & & & & & & & \\
\hline Velký cicavec & Mammalia & 20 & 0,4 & - & 121,2 & 2,3 & - & - \\
\hline Stredný cicavec & Mammalia & 92 & 1,8 & - & 163,0 & 3,1 & - & - \\
\hline Malý hlodavec & Rodentia & 3 & 0,1 & - & 0,3 & 0,0 & - & - \\
\hline Cicavec & Mammalia & 28 & 0,5 & - & 38,9 & 0,7 & - & - \\
\hline SPOLU & & 143 & 2,7 & 0 & 323,4 & 6,2 & 0 & 0 \\
\hline Vtáky & Aves & & & & & & & \\
\hline Kura domáca & Gallus domesticus & 19 & 0,4 & 0,8 & 16,2 & 0,3 & 0,9 & 8 \\
\hline Hus domáca & Anser domesticus & 6 & 0,1 & 0,2 & 9,9 & 0,2 & 0,5 & 3 \\
\hline Morka domáca & Meleagris domesticus & 1 & 0,0 & 0,0 & 2,1 & 0,0 & 0,1 & 1 \\
\hline Neurčený vták (kost') & Aves indet. & 23 & 0,4 & - & 12,0 & 0,2 & - & - \\
\hline SPOLU & & 49 & 0,9 & 1,1 & 40,2 & 0,8 & 1,5 & 12 \\
\hline Plazy & Reptilia & & & & & & & \\
\hline Korytnačka močiarna & Emys orbicularis & 14 & 0,3 & 0,6 & 4,5 & 0,1 & 0,2 & 4 \\
\hline Ryby & Pisces & & & & & & & \\
\hline Jeseter & Acipenser sp. & 23 & 0,4 & 1,0 & 25,0 & 0,5 & 1,4 & 2 \\
\hline Kapor rybničný & Cyprinus carpio & 627 & 12,1 & 25,9 & 275,8 & 5,3 & 15,0 & 39 \\
\hline Lieň sliznatý & Tinca tinca & 5 & 0,1 & 0,2 & 0,9 & 0,0 & 0,0 & 4 \\
\hline Jalec maloústy & Leuciscus leuciscus & 2 & 0,0 & 0,1 & 0,2 & 0,0 & 0,0 & 1 \\
\hline Belička európska & Alburnus alburnus & 1 & 0,0 & 0,0 & 0,1 & 0,0 & 0,0 & 1 \\
\hline Štuka severná & Esox lucius & 893 & 17,2 & 36,9 & 182,3 & 3,5 & 9,9 & 32 \\
\hline Sumec vel'ký & Silurus glanis & 85 & 1,6 & 3,5 & 179,2 & 3,4 & 9,7 & 6 \\
\hline Kapor/sumec? & cf. Cyprinus/Silurus & 556 & 10,7 & 23,0 & 124,8 & 2,4 & 6,8 & - \\
\hline Kaprovité & Cyprinidae & 24 & 0,5 & 1,0 & 4,8 & 0,1 & 0,3 & 3 \\
\hline Neurčená ryba (kost') & Pisces indet. & 2608 & 50,1 & - & 575,3 & 11,1 & - & - \\
\hline SPOLU & & 4824 & 92,8 & 91,5 & 1368,4 & 26,3 & 43,0 & 88 \\
\hline
\end{tabular}


Tabela 2. Pokračovanie.

\begin{tabular}{|c|c|c|c|c|c|c|c|c|}
\hline \multirow{2}{*}{\multicolumn{2}{|c|}{ Taxón }} & \multirow{2}{*}{$\frac{\text { Počet }}{n}$} & \multicolumn{2}{|c|}{$\begin{array}{l}\text { Relatívny počet } \\
\text { nálezov }\end{array}$} & \multirow{2}{*}{$\frac{\text { Hmotnost' }}{\text { w }}$} & \multicolumn{2}{|c|}{$\begin{array}{l}\text { Relatívna hmotnost' } \\
\text { nálezov }\end{array}$} & \multirow{2}{*}{$\begin{array}{c}\begin{array}{c}\text { Počet } \\
\text { jedincov }\end{array} \\
\mathrm{MNI}\end{array}$} \\
\hline & & & $\% \mathrm{n}$ & $\%$ NISP & & $\% \mathrm{w}$ & $\%$ WISP & \\
\hline Bezstavovce & Evertebrata & & & & & & & \\
\hline Rak riečny & cf. Astacus astacus & 43 & 0,8 & 1,8 & 3,8 & 0,1 & 0,2 & 1 \\
\hline Pásikavec lesostepný & Cepaea cf. vindobonensis & 2 & 0,0 & 0,1 & 0,6 & 0,0 & 0,0 & 1 \\
\hline SPOLU & & 45 & 0,9 & 1,9 & 4,4 & 0,1 & 0,2 & 2 \\
\hline Iné & & & & & & & & \\
\hline Vták (?) (škrupiny) & cf. Aves & 5 & 0,1 & - & 0,1 & 0,0 & - & - \\
\hline Neurčené (kost') & Indet. & 1 & 0,0 & - & 0,2 & 0,0 & - & - \\
\hline SPOLU & & 6 & 0,1 & 0 & 0,3 & 0,0 & 0 & 0 \\
\hline Domáce & & 134 & 2,6 & - & 1018,9 & 37,0 & - & 44 \\
\hline Divé & & 4895 & 94,2 & - & 1400,3 & 50,8 & - & 102 \\
\hline Domáce/divé & & 172 & 3,3 & - & 335,4 & 12,2 & - & - \\
\hline Určené & & 2421 & 46,5 & - & 1843,6 & 35,4 & - & 146 \\
\hline Neurčené & & 2780 & 53,5 & - & 911,0 & 17,5 & - & - \\
\hline SPOLU & & 5201 & 100,0 & 100,0 & 2754,6 & 100,0 & 100,0 & 146 \\
\hline
\end{tabular}
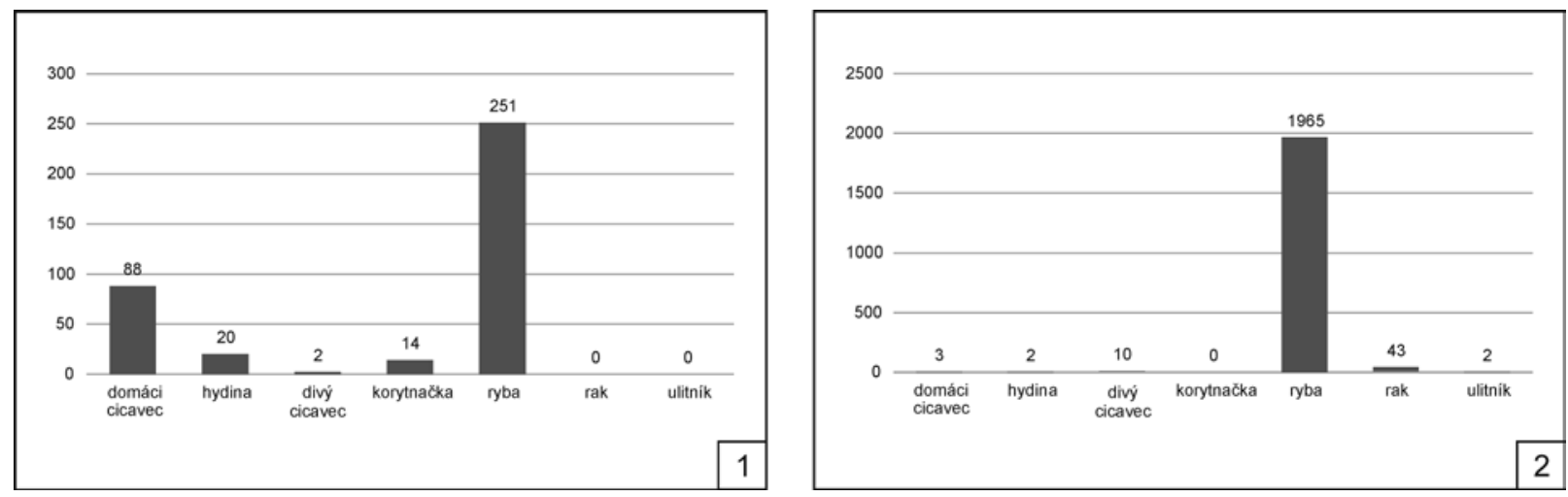

Obr. 9. Nitra-Zoborský kláštor. Zastúpenie taxónov v sondách (\% NISP). 1 - sonda 2/03 ( $\sum$ = 375; príbytok 3); 2 - sonda 4/02/03 ( $\sum$ = 2025; príbytok 9).

stravovania a hospodársko-ekonomické zázemie lokalít. Umelý odchov jelenej, srnčej a dančej zveri na gýmešskom panstve sa iste podielal na jedálničku Forgáčovcov (Eliaš 2010; Vozák/Bielich, v tlači). V kláštore sa zvyšky vysokej zveri alebo diviaka neobjavujú, dominujú ryby, plazy a menšie cicavce (bobor, vydra). Z mesta Nitra pochádzajú iba ojedinelé doklady konzumácie rýb (Miklíková 2007, 130) a na hradoch absentujú, príp. neboli identifikované. Napriek archívnym prameňom, ktoré svedčia o oblube rýb u šlachty a meštanov (Hlavačková 2015), postrádame ich zachytenie na hradoch, čo dozaista súvisí najmä s metodikou odberu vzoriek v teréne a rozdielmi vo vel'kosti kostí rýb a cicavcov. Okrem rozdielov v sortimente divých zvierat možno sledovat i odlišnosti v zastúpení vtákov na vybraných súboroch, najmä hydiny (obr. 8: 2). Na Gýmeši sú ich kosti početné (20,4 \% NISP) a objavujú sa i v meste $(5,1 \%)$, zatial čo na Oponickom hrade $(3,5 \%)$ a v kláštore pod Zoborom (1\%) sa vyskytli minimálne.

V kláštore sa sortiment druhov zvierat mení v závislosti od kontextu (tabela 3). Podiel divých druhov nie je vo všetkých vzorkách rovnako výrazný. Odlišnosti sú vo vzorkách 6-11, ktoré pochádzajú z exteriéru mníšskych príbytkov. Kontext vzoriek naznačuje, že by mohlo íst̉ o materiál zo stredovekej fázy osídlenia lokality (pozri kapitolu Materiál a metódy). Odlišnosti sme zaznamenali aj v sortimente 
Tabela 3. Nitra-Zoborský kláštor. Zastúpenie taxónov vo vzorkách (podl’a počtu nálezov).

\begin{tabular}{|c|c|c|c|c|c|c|c|c|c|c|c|c|}
\hline \multirow{2}{*}{ Taxón } & \multicolumn{12}{|c|}{ Číslo vzorky } \\
\hline & 1 & 2 & 3 & 4 & 5 & 6 & 7 & 8 & 9 & 10 & 11 & 12 \\
\hline \multicolumn{13}{|l|}{ Domáce cicavce } \\
\hline Bos taurus & - & - & 7 & 1 & 11 & - & - & 3 & 3 & - & 1 & - \\
\hline Ovis aries & - & - & 1 & 1 & 6 & - & - & 1 & - & - & - & - \\
\hline Ovis/Capra & - & - & 12 & 8 & 29 & - & - & 2 & - & 2 & 1 & - \\
\hline Sus domesticus & - & - & 3 & 3 & 3 & - & 2 & 2 & - & - & 2 & - \\
\hline Sus cf. domesticus & - & - & 1 & - & - & - & - & - & - & - & - & - \\
\hline Canis familiaris & 2 & - & - & - & - & - & - & - & - & - & - & - \\
\hline Equus caballus & - & - & 1 & - & - & - & - & - & - & - & - & - \\
\hline SPOLU & 2 & 0 & 25 & 13 & 49 & 0 & 2 & 8 & 3 & 2 & 4 & 0 \\
\hline \multicolumn{13}{|l|}{ Divé cicavce } \\
\hline Lutra lutra & - & - & - & - & - & - & - & - & - & - & - & 7 \\
\hline Castor fiber & - & - & - & 2 & - & - & - & - & - & - & - & - \\
\hline Glis glis & - & - & - & - & - & - & - & - & - & - & - & 3 \\
\hline SPOLU & - & - & - & 2 & - & - & - & - & - & - & - & 10 \\
\hline \multicolumn{13}{|l|}{ Neurčené cicavce } \\
\hline Mammalia indet. & 2 & 5 & 7 & 27 & 42 & 4 & 10 & 25 & - & 3 & 15 & - \\
\hline Rodentia indet. & - & - & - & - & - & - & - & - & - & - & - & 3 \\
\hline SPOLU & 2 & 5 & 7 & 27 & 42 & 4 & 10 & 25 & 0 & 3 & 15 & 3 \\
\hline \multicolumn{13}{|l|}{ Vtáky } \\
\hline Gallus domesticus & 1 & 7 & - & 4 & 2 & 2 & - & 1 & - & - & - & 2 \\
\hline Anser domesticus & - & - & - & 2 & 3 & - & - & 1 & - & - & - & - \\
\hline Meleagris domesticus & - & - & - & 1 & - & - & - & - & - & - & - & - \\
\hline Aves indet. & - & 9 & - & 9 & 1 & 2 & 1 & 2 & - & 1 & 1 & 2 \\
\hline SPOLU & 1 & 16 & 0 & 16 & 6 & 4 & 1 & 4 & 0 & 1 & 1 & 4 \\
\hline \multicolumn{13}{|l|}{ Plazy } \\
\hline Emys orbicularis & 7 & 7 & - & - & - & - & - & - & - & - & - & - \\
\hline \multicolumn{13}{|l|}{ Ryby } \\
\hline Acipenser sp. & - & - & - & - & - & - & - & - & - & - & - & 23 \\
\hline Cyprinus carpio & 130 & 10 & - & - & - & - & - & - & - & - & - & 487 \\
\hline Tinca tinca & - & - & - & - & - & - & - & - & - & - & - & 5 \\
\hline Leuciscus idus & - & - & - & - & - & - & - & - & - & - & - & 2 \\
\hline Alburnus alburnus & - & - & - & - & - & - & - & - & - & - & - & 1 \\
\hline Esox lucius & 75 & 2 & - & - & - & - & - & - & - & - & - & 816 \\
\hline Silurus glanis & 12 & 3 & - & - & - & - & - & - & - & - & - & 70 \\
\hline cf. Cyprinus/Silurus & - & - & - & - & - & - & - & - & - & - & - & 556 \\
\hline Cyprinidae & 5 & 14 & - & - & - & - & - & - & - & - & - & 5 \\
\hline Pisces indet. & 44 & 301 & - & - & - & 2 & - & - & - & - & - & 2261 \\
\hline SPOLU & 266 & 330 & 0 & 0 & 0 & 2 & 0 & 0 & 0 & 0 & 0 & 4226 \\
\hline \multicolumn{13}{|l|}{ Bezstavovce } \\
\hline cf. Astacus astacus & - & - & - & - & - & - & - & - & - & - & - & 43 \\
\hline Cepaea cf. vindobonensis & - & - & - & - & - & - & - & - & - & - & - & 2 \\
\hline SPOLU & 0 & 0 & 0 & 0 & 0 & 0 & 0 & 0 & 0 & 0 & 0 & 45 \\
\hline \multicolumn{13}{|l|}{ Iné } \\
\hline Aves (?) (škrupiny vajec) & - & - & - & - & - & - & - & - & - & - & - & 5 \\
\hline Indet. & - & 1 & - & - & - & - & - & - & - & - & - & - \\
\hline
\end{tabular}



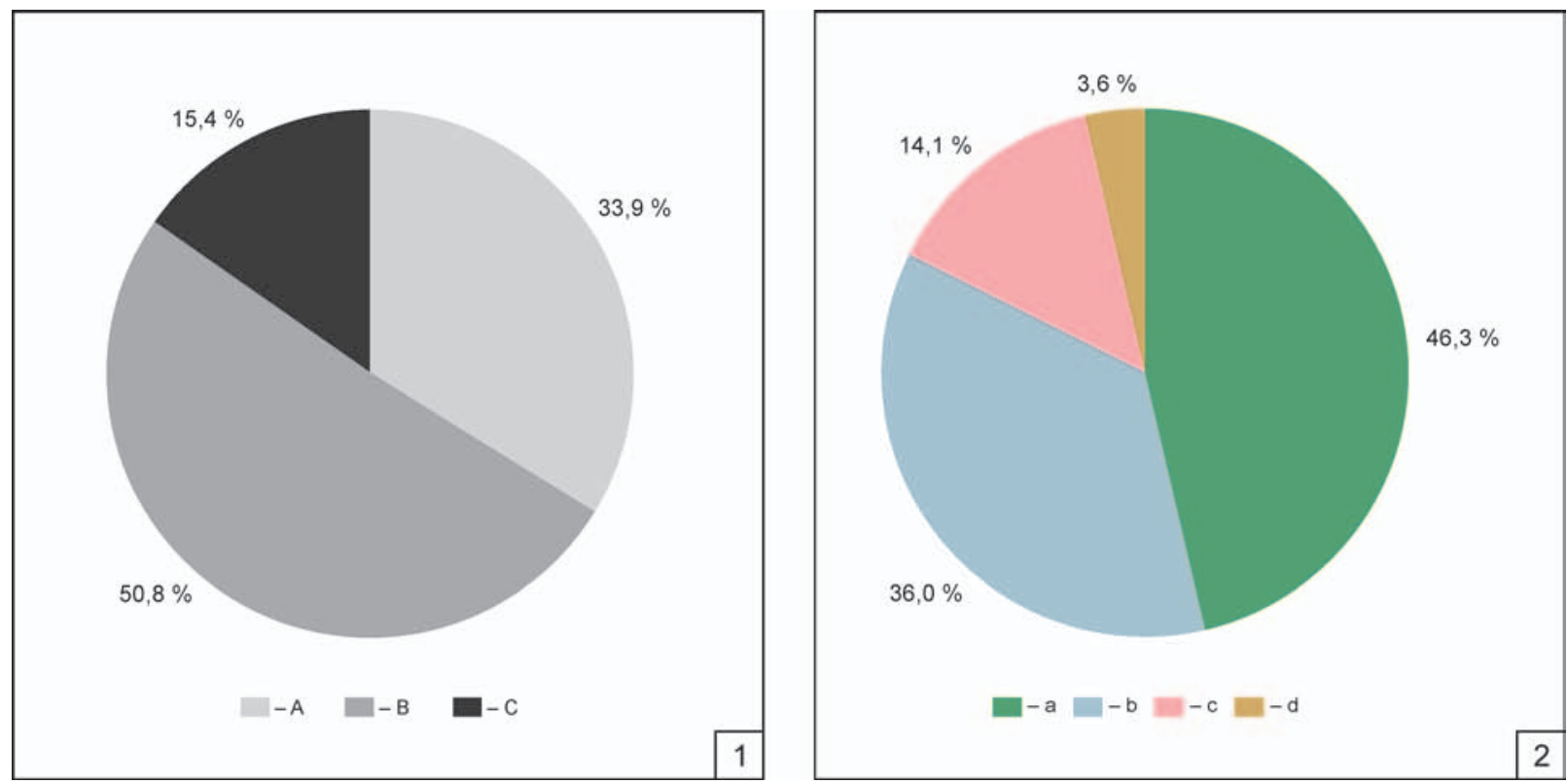

Obr. 10. Nitra-Zoborský kláštor. Anatomická štruktúra v skupine hospodárskych druhov zvierat. Pes a kôň nezapočítaný. 1 - zastúpenie kostí (\% NISP) podla kvalitatívnych kategórií A - top mäsa; B - stredne kvalitné mäso; C - jatočný odpad. 2 - podiel kostí A a B kategórie (\% WISP) na celkovej hmotnosti kostí so svalovinou (723,5 g). Legenda: a - hovädzie; b - ovčie/kozie; c - bravčové; $d$ - hydinové.

a zastúpení druhov v rámci dvoch mníšskych príbytkov (obr. 9). Je evidentné, že v rámci sondy 2, z preskúmanej časti príbytku 3 pochádzajú aj kosti bežne nekonzumovaných domácich zvierat, psa (vzorka 1) a koňa (vzorka 3). Vezmúc do úvahy „stravovaciu“ interpretačnú rovinu, tieto kosti indikujú odpad z chronologicky sídliskového horizontu po ukončení pôsobenia kamaldulov. Avšak aj iné vzorky z tejto sondy vykazujú prítomnost’ domácich zvierat, no bežne konzumovaných - ovce/kozy, tura, svine (vzorka 3-5), kury (všade okrem vzorky 3), husi (vzorky 4-5) a morky domácej (vzorka 4). Naopak, kosti divo žijúcich druhov, najmä rýb, sa v tejto sonde koncentrujú len vo vzorkách 1, 2 a 4 (obr. 9: 1). Tieto vzorky súbežne vykazujú minimum alebo absenciu domácich druhov. Materiál zo sondy 4 je odlišný (obr. 9: 2). S výnimkou kostí tura, odkrytých v exteriéri (vzorka 9), domáce druhy absentujú. Výnimočnou sa vo vzorke 12 javí kost' kury.

\section{Domáce cicavce a hydina}

Domáce cicavce v súbore reprezentujú kosti tura (Bos taurus), svine (Sus domesticus), ovce (Ovis aries), koňa (Equus caballus) a psa (Canis familiaris). Domáce vtáky zahŕňajú kosti kury (Gallus domesticus), husi (Anser domesticus), morky (Meleagris domesticus) a azda aj škrupiny vajec. S výnimkou morky (pozri nasledujúcu kapitolu) ide o bežné hospodárske druhy zvierat obdobia novoveku, ktorých chov a konzumáciu mäsa dokladujú aj archeozoologické nálezy z regiónu Nitry. Temer polovica kostí v tejto skupine zvierat patrila malým prežúvavcom, pravdepodobne ovciam $(n=63=2,6 \%$ NISP; tabela 2$)$. V kláštore nebola identifikovaná jediná kost' kozy. Doplnok tvorí hydina ( $n=26=1,1 \%)$, tur ( $n=26=1,1 \%)$ a sviňa ( $\mathrm{n}=15=0,6 \%$. Ovce/kozy prevažujú aj pohladu minimálneho počtu jedincov (MNI = 16). Nasleduje hydina $(\mathrm{MNI}=11)$, sviňa $(\mathrm{MNI}=8)$ a tur $(\mathrm{MNI}=6)$. Ak zohladníme hmotnost' nálezov poradie je odlišné. Dominuje tur (28,4\% WISP) a ovce/kozy tvoria zhruba polovicou nálezov $(15,3 \%)$. Podiel svine je 6,8 \% a podiel hydiny iba $1,5 \%$.

Podobne ako $\mathrm{v}$ celkovom sortimente $\mathrm{i} \mathrm{v}$ zastúpení domácich druhov zvierat pozorujeme na nitrianskych lokalitách výrazné rozdiely. V meste jednoznačne dominuje tur, doplnený ovčími/kozími kostami (Miklíková/Fabiš 2004). Podobne sa javí súbor Oponického hradu, i ked’ tu je v porovnaní s mestom početnost tura o polovicu nižšia a vo väčšej miere sú zastúpené ovčie/kozie a bravčové kosti (Repka/Sater/Šimunková 2017). Z hladiska stravovania (konzumácia mäsa) sa sortiment kláštora najviac podobá hradu Gýmeš, kde síce evidujeme prevahu kostí svine, no registrujeme vyšší podiel hydiny. Naviac, i na tomto hrade je prítomná morka domáca (Vozák/Bielich, v tlači). Tieto trendy sú založené na porovnaní 
Tabela 4. Nitra-Zoborský kláštor. Anatomická skladba súboru kostí domácich druhov zvierat (podla počtu a hmotnosti v gramoch). * - spolu nálezy Ovis aries a Ovis/Capra; ** - nález Sus cf. domesticus nezapočítaný. Kategórie A, B, C podla kvality a množstva svaloviny na kostiach (Uerpmann 1973, doplnené o hydinu).

\begin{tabular}{|c|c|c|c|c|c|c|c|c|c|c|c|c|c|c|c|c|c|}
\hline \multirow{2}{*}{ 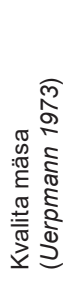 } & \multirow[t]{2}{*}{ Element } & \multicolumn{2}{|r|}{ 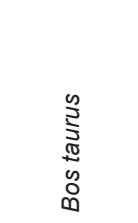 } & \multicolumn{2}{|c|}{$\begin{array}{l}* \\
\frac{\pi}{0} \\
\frac{0}{\pi} \\
\frac{0}{0} \\
\frac{\omega}{3} \\
0\end{array}$} & \multicolumn{2}{|c|}{ 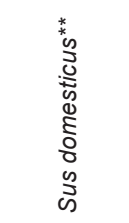 } & \multicolumn{2}{|c|}{ 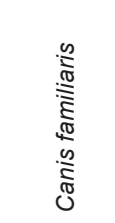 } & \multicolumn{2}{|c|}{ 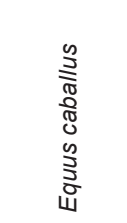 } & \multicolumn{2}{|c|}{ 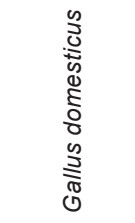 } & \multicolumn{2}{|c|}{ 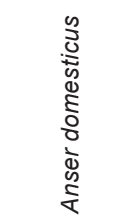 } & \multicolumn{2}{|c|}{ 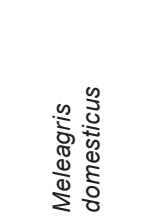 } \\
\hline & & $\mathrm{n}$ & w & $\mathrm{n}$ & w & $\mathrm{n}$ & w & $\mathrm{n}$ & w & $\mathrm{n}$ & w & $\mathrm{n}$ & w & $\mathrm{n}$ & w & $\mathrm{n}$ & w \\
\hline \multirow{15}{*}{$\begin{array}{l}\widehat{\leq} \\
\text { 응 }\end{array}$} & atlas & - & - & 3 & 11,2 & - & - & - & - & - & - & - & - & - & - & - & - \\
\hline & vertebrae cervicales & - & - & - & - & - & - & - & - & - & - & 1 & 0,2 & - & - & - & - \\
\hline & vertebrae thoracicae & 1 & 6,5 & 1 & 2,1 & - & - & - & - & - & - & - & - & - & - & - & - \\
\hline & vertebrae lumales & 1 & - & 1 & 5,5 & - & - & - & - & - & - & - & - & - & - & - & - \\
\hline & sacrum & - & - & - & - & - & - & - & - & - & - & 1 & 1,2 & - & - & - & - \\
\hline & pelvis & - & - & 2 & 14,2 & - & - & - & - & - & - & - & - & - & - & - & - \\
\hline & ischium (acetabulum) & - & - & 1 & 2,2 & - & - & - & - & - & - & - & - & - & - & - & - \\
\hline & ilium & 2 & 20,3 & - & - & - & - & - & - & - & - & - & - & - & - & - & - \\
\hline & synsacrum & - & - & - & - & - & - & - & - & - & - & 1 & 0,3 & - & - & - & - \\
\hline & femur & 2 & 27,9 & 2 & 7,7 & 2 & 14,8 & - & - & - & - & - & - & - & - & - & - \\
\hline & scapula & - & - & 3 & 11,4 & 1 & 5,6 & - & - & - & - & 2 & 0,5 & 1 & 1,1 & - & - \\
\hline & coracoideum & - & - & - & - & - & - & - & - & - & - & 1 & 0,2 & 2 & 2,9 & 1 & 2,1 \\
\hline & sternum & - & - & - & - & - & - & - & - & - & - & 1 & 0,3 & - & - & - & - \\
\hline & humerus & 1 & 57,0 & 6 & 41,0 & 1 & 18,6 & - & - & - & - & 2 & 4 & 1 & 3,1 & - & - \\
\hline & SPOLU (A) & 7 & 111,7 & 19 & 95,3 & 4 & 39 & 0 & 0 & 0 & 0 & 9 & 6,7 & 4 & 7,1 & 1 & 2,1 \\
\hline \multirow{9}{*}{ 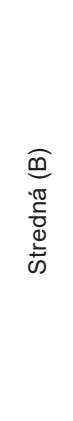 } & radius & 1 & 89,0 & 6 & 31,2 & - & - & - & - & - & - & 2 & 1,3 & 1 & 1 & - & 132,5 \\
\hline & ulna & - & - & 1 & 2,5 & 1 & 10,6 & - & - & - & - & 1 & 0,1 & 1 & 1,8 & - & 19 \\
\hline & tibia & 3 & 28,9 & 15 & 102,6 & 2 & 29,9 & - & - & - & - & - & - & - & - & - & 181,4 \\
\hline & tibiotarsus & - & - & - & - & - & - & - & - & - & - & 2 & 5,5 & - & - & - & 7,5 \\
\hline & mandibula & 2 & 64,1 & 2 & 7,5 & 3 & 22,4 & - & - & - & - & - & - & - & - & - & 101 \\
\hline & mandibula et dens & - & - & 1 & 6,8 & - & - & - & - & - & - & - & - & - & - & - & 7,8 \\
\hline & vertebrae indet. & - & - & - & - & _- & - & - & - & - & - & 2 & 0,6 & - & - & - & 2,6 \\
\hline & costa & 7 & 41,3 & 13 & 14,5 & - & - & - & - & - & - & - & - & - & - & - & 75,8 \\
\hline & SPOLU (B) & 13 & 223,3 & 38 & 165,1 & 6 & 62,9 & 0 & 0 & 0 & 0 & 7 & 7,5 & 2 & 2,8 & 0 & 527,6 \\
\hline \multirow{15}{*}{ 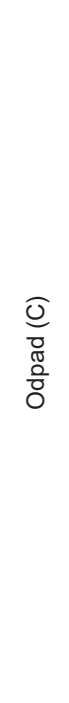 } & maxilla et dens & - & - & 1 & 8,3 & - & - & - & - & - & - & - & - & - & - & - & 9,3 \\
\hline & incisivus 1 superior & - & - & - & - & 1 & 2,3 & - & - & _- & - & - & - & - & _- & - & 3,3 \\
\hline & molar & - & - & 1 & 1,2 & - & - & - & - & - & - & - & - & - & - & - & 2,2 \\
\hline & molar 1 superior & - & - & - & - & 1 & 5,3 & - & - & - & - & - & - & - & - & - & 6,3 \\
\hline & molar 2 superior & - & - & - & - & _- & - & - & - & 1 & 45,4 & - & - & - & - & - & 46,4 \\
\hline & molar 3 superior & 1 & 21,2 & - & - & 1 & 3,1 & - & - & - & - & - & - & - & - & - & 26,3 \\
\hline & metacarpus 4 & - & - & - & - & - & - & 1 & 3,5 & - & - & - & - & - & - & - & 4,5 \\
\hline & metacarpus 5 & - & - & - & - & - & - & 1 & 3,2 & - & - & - & - & - & - & - & 4,2 \\
\hline & metapodium & 1 & 19,1 & - & - & 1 & 3,2 & - & - & - & - & - & - & - & - & - & 24,3 \\
\hline & metatarsus & 1 & 113,3 & - & - & - & - & - & - & - & - & - & - & - & - & - & 114,3 \\
\hline & carpometacarpus & - & - & - & - & - & - & - & - & - & - & 3 & 2 & - & - & - & 5 \\
\hline & talus & 1 & 18,3 & 4 & 12,2 & 1 & 9,2 & - & - & - & - & - & - & - & - & - & 45,7 \\
\hline & phalanx & 1 & 1,9 & - & - & - & - & - & - & - & - & - & - & - & - & - & 2,9 \\
\hline & phalanx 3 & 1 & 14,1 & - & - & - & - & - & - & - & - & - & - & - & - & - & 15,1 \\
\hline & SPOLU (C) & 6 & 187,9 & 6 & 21,7 & 5 & 23,1 & 2 & 6,7 & 1 & 45,4 & 3 & 2 & 0 & 0 & 0 & 309,8 \\
\hline \multicolumn{2}{|c|}{ SPOLU } & 26 & 522,9 & 63 & 282,1 & 15 & 125 & 2 & 6,7 & 1 & 45,4 & 19 & 16,2 & 6 & 9,9 & 1 & 2,1 \\
\hline
\end{tabular}


Tabela 5. Nitra-Zoborský kláštor. Odhad veku v čase smrti (okrem rýb, podla počtu nálezov).

\begin{tabular}{|c|c|c|c|c|c|c|c|c|c|c|c|c|c|c|c|c|c|c|c|}
\hline Relatívny vek & 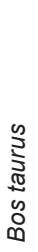 & $\begin{array}{l}\stackrel{\infty}{2} \\
\frac{0}{\sigma} \\
.0 \\
0 \\
0\end{array}$ & $\begin{array}{l}\frac{\pi}{2} \\
\frac{\pi}{\pi} \\
\frac{0}{3} \\
0\end{array}$ & 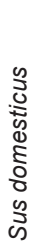 & 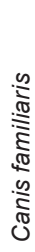 & 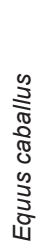 & 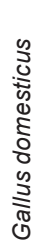 & 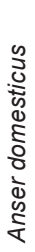 & 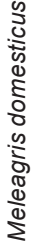 & $\frac{\sqrt{3}}{\stackrel{\pi}{5}}$ & 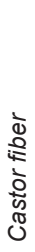 & $\begin{array}{l}\frac{y}{5} \\
\text { के }\end{array}$ & 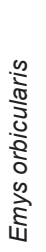 & 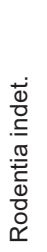 & 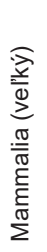 & 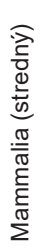 & 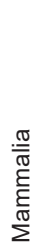 & $\stackrel{\infty}{\stackrel{\infty}{\gtrless}}$ & $\mathrm{n}$ \\
\hline vel'mi juvenilný & - & - & 12 & 1 & - & - & - & - & - & - & - & - & - & - & - & 1 & - & - & 14 \\
\hline juvenilný & 1 & 2 & 17 & - & - & - & - & - & - & - & - & - & - & - & - & - & - & 2 & 22 \\
\hline juvenilný (?) & 6 & - & 7 & 1 & - & - & - & - & - & - & - & - & 1 & - & 1 & 6 & 2 & - & 24 \\
\hline juvenilný/subadultný & 2 & 1 & 7 & 2 & - & - & 3 & - & - & - & - & 3 & - & - & - & 5 & - & 2 & 25 \\
\hline subadultný & 1 & - & - & 1 & - & - & - & - & 1 & 2 & - & - & - & - & - & - & - & - & 5 \\
\hline subadultný (?) & 7 & 2 & 2 & 1 & - & - & - & 4 & - & - & - & - & - & - & - & 6 & - & - & 22 \\
\hline subadultný/adultný & 3 & 1 & 1 & 3 & - & - & 3 & 2 & - & 1 & - & - & 1 & 1 & - & 1 & - & - & 17 \\
\hline adultný & 1 & - & 1 & - & 2 & - & - & - & - & - & - & - & 5 & - & - & - & - & - & 9 \\
\hline adultný (?) & - & - & - & 1 & - & 1 & 7 & - & - & 4 & 1 & - & 3 & 1 & 1 & 2 & - & 2 & 23 \\
\hline nie juvenilný & 1 & 1 & - & 2 & - & - & - & - & - & - & - & - & - & - & 3 & 1 & - & - & 8 \\
\hline SPOLU & 22 & 7 & 47 & 12 & 2 & 1 & 13 & 6 & 1 & 7 & 1 & 3 & 10 & 2 & 5 & 22 & 2 & 6 & 169 \\
\hline
\end{tabular}

počtu identifikovaných fragmentov (NISP) pri jednotlivých druhoch, mení sa ale pri porovnaní hmotnosti fragmentov (WISP), minimálneho počtu jedincov (MNI) a pri použití iných kvantifikačných metód. Hmotnost̉ kostí najlepšie vystihuje podiel skonzumovanej svaloviny (mäsa). Pri interpretácii týchto výsledkov sa zohladňuje i anatomická štruktúra súboru, t. j. kvantita i kvalita osvalenia jednotlivých elementov kostry. V analyzovanom súbore (obr. 10: 1; tabela 4) tento spôsob hodnotenia zvyškov ukazuje pri domácich cicavcoch na prevahu kvalitne až stredne kvalitných častí tela (kategórie A a B podla Uerpmann 1973). Podiel jatočného odpadu (kategória C), ktorý zahŕňa kosti tváre, chvosta a koncových častí končatín, je v skúmanom súbore celkovo nízky (15,4% NISP; 24,5 \% WISP). Ak porovnáme tura a ovcu/ kozu, u tura registrujeme vyšší podiel jatočného odpadu (tur 35,9 \% WISP a ovca/koza 7,7 \% WISP; obr. 10: 2) Pre posúdenie kvality a množstva mäsa domácich zvierat skonzumovaných v kláštore je dôležitý aj vek jedincov v čase smrti (tabela 5). Výsledky svedčia o prevahe zvierat v nedospelom veku (86,9\% NISP), čo platí najmä pre ovčie/kozie ( 94,3 \% NISP) a hovädzie ( $81 \%)$. Stav výmeny a opotrebovania zubov i uzatváranie štrbín epifýz dlhých kostí informácie o veku spresňujú. Nálezy svedčia o tom, že ovce/kozy boli porážane vo veku do dvoch $(\mathrm{MNI}=2)$, šiestich $(\mathrm{MNI}=10), 12(\mathrm{MNI}=2), 12-24$ mesiacov $(\mathrm{MNI}=1)$. Ojedinele je zaznamenaná porážka vo veku 3 rokov $(\mathrm{MNI}=1)$. Nízky jatočný vek sme zistili aj u turov. Dáta ukazujú na zvieratá vo veku do šest' $(\mathrm{MNI}=2), 24-30(\mathrm{MNI}=1)$ až 42 mesiacov $(\mathrm{MNI}=1)$. K porážke ošípanej máme len pár dát, ktoré indikujú nedospelé a mladé zvieratá: 1-3 mesiace $(\mathrm{MNI}=1)$ a 1-1,5 roka $(\mathrm{MNI}=1)$. Žial', pohlavie jatočných zvierat nebolo možné stanovit vzhl'adom na vysoké zastúpenie nedospelých jedincov a absenciu diagnostických kostí príp. zubov.

Čo sa týka hydiny, kosti kury, husi a morky z kláštora reprezentujú kvalitne osvalené časti vtáčieho skeletu. Prevažujú nedospelé jedince (tabela 4; 5). Výnimkou je kura, u ktorej registrujeme aj výskyt menej osvalených elementov (carpometacarpus) a dospelých jedincov, čo môže indikovat rozdiely v jej exploatácii (možno lokálny chov sliepok na vajcia) alebo iné spracovanie a úprava mäsa v kuchyni. Škrupiny vajec $(n=5)$, ktoré sme identifikovali medzi nálezmi vo vzorke 12 neboli zatial' druhovo určené, no vzhl’adom na ich hrúbku odhadujeme, že patrili druhu vel'kosti domácej kury. Konzumácia vajec bola v rámci diétneho stravovania mníchov tolerovaná, ba predstavovala významnú zložku kláštornej kuchyne (napr. Moreno-García/Detry 2010). Kontext našich nálezov svedčí jasne o ich konzumácii v príbytku 9.

V súbore boli identifikované aj dve metakarpálne kosti psa (vzorka 1) a zub koňa (vzorka 3). O konzumácii mäsa týchto druhov zvierat však v kontexte kamaldulského kláštora neuvažujeme. V prípade vzorky 3, nálezy korelujú s obdobím výstavby kláštora. Kontext i kosti rýb vo vzorke 1 však naznačujú súvis s obdobím fungovania barokového kláštora. 
Tabela 6. Nitra-Zoborský kláštor. Výskyt mäsiarskych/kuchynských zásahov (okrem rýb, podla počtu nálezov).

\begin{tabular}{|c|c|c|c|c|c|c|c|c|c|c|c|c|c|c|c|c|c|c|c|}
\hline Mäsiarske/kuchynské zásahy & 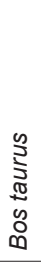 & 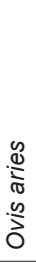 & $\begin{array}{l}\frac{\pi}{2} \\
\frac{0}{\pi} \\
\frac{0}{5} \\
0\end{array}$ & 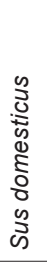 & 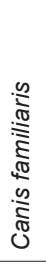 & 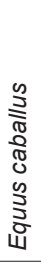 & 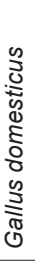 & 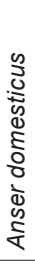 & 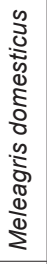 & 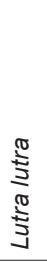 & 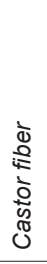 & $\begin{array}{l}\frac{0}{5} \\
\stackrel{0}{0} \\
0\end{array}$ & 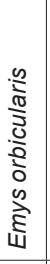 & 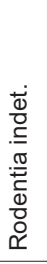 & 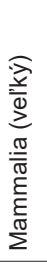 & 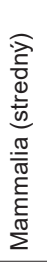 & 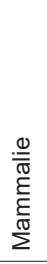 & $\stackrel{\infty}{\stackrel{\infty}{<}}$ & $\mathrm{n}$ \\
\hline rozseknuté & 2 & - & 3 & 1 & - & - & - & 1 & - & - & 1 & - & - & - & - & 2 & - & - & 10 \\
\hline rozseknuté ('’ažšia ostrá čepel'sekáč?) & 1 & - & 1 & - & - & - & - & - & - & - & - & - & - & - & - & - & - & - & 2 \\
\hline odseknutie & 1 & - & 3 & - & - & - & - & - & - & - & - & - & - & - & - & - & 1 & - & 5 \\
\hline odseknutie malej časti & - & - & - & - & - & - & - & - & - & - & - & - & 1 & - & - & - & - & - & 1 \\
\hline zásek pri rozseknutí & 2 & - & - & 1 & - & - & - & - & - & - & - & - & - & - & 1 & - & 1 & - & 5 \\
\hline asi odseknuté & 1 & - & - & - & - & - & - & - & - & - & - & - & - & - & - & - & - & - & 1 \\
\hline asi rozseknuté & 1 & 2 & 4 & - & - & - & 1 & - & - & - & - & - & 4 & - & - & 2 & 1 & - & 15 \\
\hline jemný zárez & - & 1 & - & 1 & - & - & - & - & 1 & - & - & - & - & - & - & - & - & - & 3 \\
\hline asi zárez & - & - & - & - & - & - & - & - & - & - & - & - & 3 & - & - & - & - & - & 3 \\
\hline orezávanie kosti & 1 & - & - & - & - & - & - & - & - & - & - & - & - & - & - & - & - & - & 1 \\
\hline asi rozštiepené & 2 & 1 & 4 & 1 & - & - & 1 & - & - & - & - & - & - & - & - & - & - & - & 9 \\
\hline zásah (?) & - & - & - & - & - & - & 1 & - & - & - & - & - & - & - & - & - & - & - & 1 \\
\hline SPOLU & 11 & 4 & 15 & 4 & 0 & 0 & 3 & 1 & 1 & 0 & 1 & 0 & 8 & 0 & 1 & 4 & 3 & 0 & 56 \\
\hline
\end{tabular}

Modifikácie štruktúry a tvaru kostí domácich zvierat, ktoré vznikli ako dôsledok ludskej činnosti, evidujeme u všetkých druhov okrem psa a koňa (tabela 6). Záseky, zárezy a intencionálne lámanie/štiepenie registrujeme najmä na u oviec/kôz (48,7\% $\left.{ }^{15} \mathrm{NISP}\right)$ a tura $(28,2 \%)$. Menej časté sú u ošípanej (10,3 \%), kury $(7,7 \%)$, husi $(2,6 \%)$ a morky (2,6 \%). Ich lokalizácia a smer zásahu súvisí so sekundárnym porciovaním tela zvierat, t. j. s kuchynským spracovaním a konzumáciou mäsa. Nálezy nesú stopy po delení končatín v kíbe, orezávaní mäsa/šliach i lámaní za účelom konzumácie špiku. Stopy opálenia kostného tkaniva registrujeme v jedinom prípade - na prstovom článku tura, ktorého povrch je čiastočne sfarbený dočierna. Táto kost’ pochádza zo vzorky 11, ktorá súvisí so stredovekým horizontom osídlenia a preto ju nemožno interpretovat' v kontexte stravovania kamaldulov. Stopy po hryzení kostí mäsožravcom (pes a mačka) sú v hodnotenom súbore zriedkavé (5,3\%), avšak prítomné. Predpokladáme, že k odpadu z mniśskych príbytkov mali predátori iba obmedzený prístup. Odpad zo stravovania a kuchyne bol likvidovaný iným spôsobom, v iných častiach kláštora. Ohryz, ktorý sme zaznamenali na kostiach tura, ovce/kozy a kury vo vzorkách 3 až 5 možno spájat’ s prítomnostou psa a mačky na lokalite v iných obdobiach. Tieto nálezy zrejme súvisia s výstavbou barokového kláštora, počas ktorého sa hromadil odpad zo stravovania robotníkov. Vel'korysé úpravy terénu spôsobili jeho premiešanie so starším materiálom.

\section{Morka domáca}

V stredoeurópskom kontexte je významný objav zvyškov morky domácej (Meleagris gallopavo f. domestica), nakol'ko neporušená krkavčia kost̉ (os coracoideum sinistra) predstavuje jeden z prvých dokladov chovu tohto vtáka na území horného Uhorka (obr. 11). Ďalšie archeologické doklady pochádzajú jedine z ned’alekého hradu Gýmeš (Vozák/Bielich, v tlači). Morky patria medzi kurotvaré vtáky (Galliformes) s výrazným pohlavným dimorfizmom. Ich vel'kostná variabilita, ovplyvnená domestikáciou, komplikuje stanovenie pohlavia a veku kostrových pozostatkov. Nálezy z oboch slovenských lokalít sú však výnimočne dobre zachované a vhodné $\mathrm{k}$ osteometrickej analýze. Získané poznatky svedčia o tom, že morka z kláštora bola výrazne menšia ako súčasné plemená tohto druhu. ${ }^{16}$ Jej rozmery nedosahujú ani

\footnotetext{
15 Vypočítané z celkového počtu zásahov registrovaných na kostiach domácich druhov zvierat (n=39).

16 Porovnanie s recentným dospelým jedincom (neznáme pohlavie a plemeno).
} 

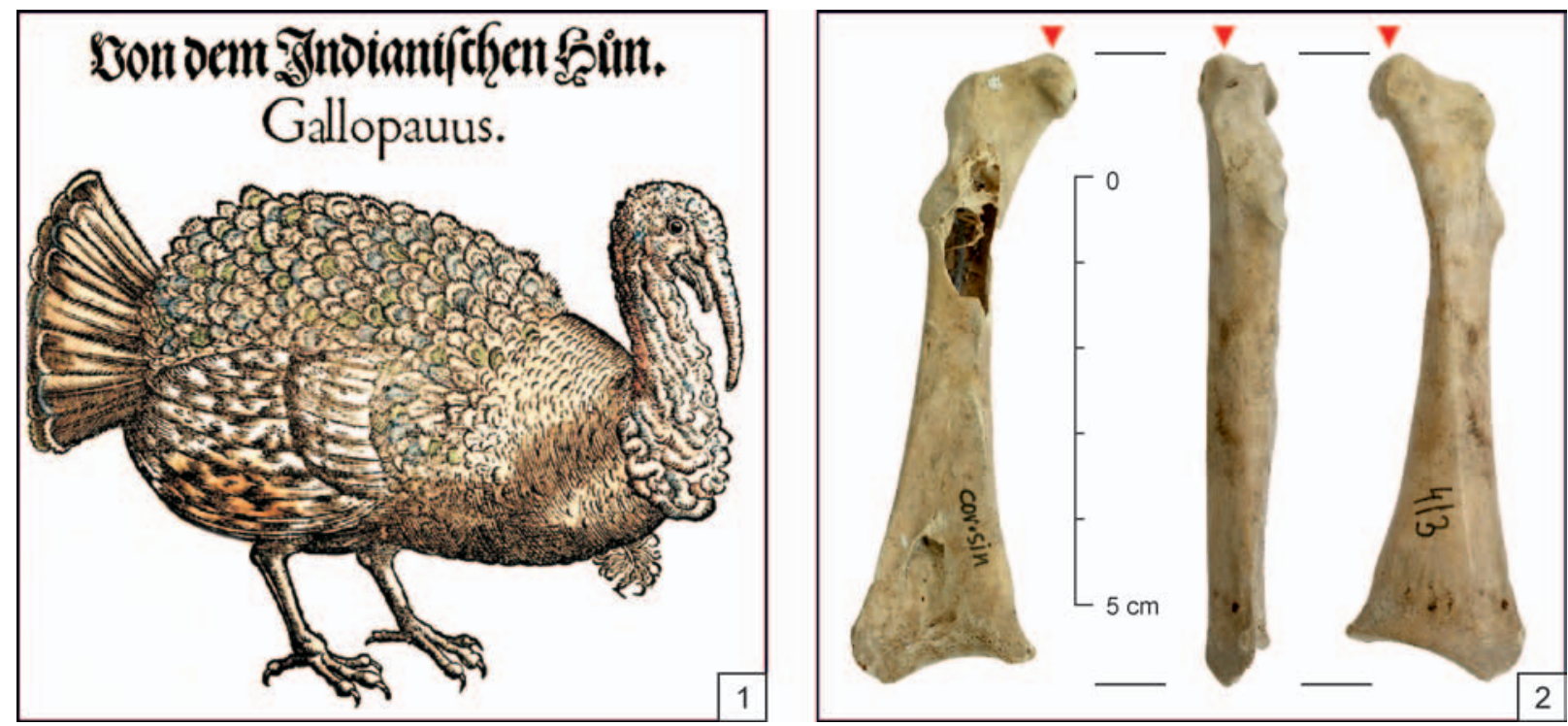

Obr. 11. Morka domáca (Meleagris gallopavo f. domestica). 1 - morka na ilustrácii z Historiae Animalium (16. stor.) od C. Gessnera. Zdroj: http://dx.doi.org/10.3931/e-rara-1946 (upravené); 2 - os coracoideum morky domácej zo Zoborského kláštora (ventrálny, laterálny a dorzálny pohl’ad). Šípka - lokalizácia drobného zárezu. Foto Z. Bielichová.

parametre nálezu z hradu Gýmešr ${ }^{17}$ a porovnanie s pôvodnou divou formou z Mexika naznačuje, že kosṫ z kláštora zrejme patrí nedospelému jedincovi, pravdepodobne samici (Bocheński/Campbell 2006, 72, tab. A5). Zaujímavostou je tiež evidencia stôp po ludskom zásahu. Plytký, krátky a vol'ným okom temer nepostrehnutelný zárez ostrým predmetom (nožíkom?) sa nachádza na proximálnej klbovej plôške facies articularis clavicularis, v oblasti úponu ligamentum acrocoracohumeralis. Indikuje manipuláciu človeka s telom mŕtveho vtáka, zrejme s cielom oddelit krídlo od trupu. Kost pochádza zo vzorky 4, spod podlahy v eremitke 3, ktorá obsahovala aj kosti inej hydiny a domácich cicavcov. Jej presné chronologické zaradenie ku kamalduskému kláštoru zostáva otázne, no je pravdepodobné, že súvisí s úpravou terénu počas výstavby kláštora. Doterajšie poznatky o čase importu moriek na európsky kontinent jednoznačne vylučujú jej súvislost’ so starším stredovekým obdobím.

Morka patrí k bažantovitým vtákom (čelad’ Phasianidae) a jej domáca forma sa vyvinula z jedného či viacerých poddruhov morky divej (Meleagris gallopavo), ktorá bola rozšírená v strednej Amerike a Mexiku (Serjeantson 2009). Genetické analýzy svedčia o tom, že domestikácia prebehla vo viacerých oblastiach a obdobiach, pričom sa morka stala dôležitým lokálnym zdrojom mäsa, najmä miestnych elít (napr. mayskej civilizácie; Speller a i. 2010; Thornton a i. 2012). Na európsky kontinent bola privezená začiatkom 16. stor. $\mathrm{v}$ súvislosti so zámorskými objavmi v Novom svete a rýchlo sa udomácnila (Benecke 1994a, 392-394). ${ }^{18}$ Bádatelia uvádzajú, že v porovnaní s kurou, ktorá prenikala z Ázie rýchlostou asi 1,5-3 km/rok, morka postupovala v Európe rýchlostou 40-50 km/rok (Crawford 1992, 307). K jej šíreniu prispeli hromadné importy a vysoká ekologická či potravná adaptabilnoste. V Amerike ju prikrmovali najmä kukuricou, ktorú doviezli Španieli na kontinent v rovnakom čase (Rebourg a i. 2003). Podla reformátora a vzdelanca Konrada de Heresbach, boli morky ešte pred rokom 1530 prakticky neznáme, no už v roku 1571 sa chovali vo vel'kých kŕdloch (Zeuner 1963, 459). Archeozoologické nálezy sú vzácne a pochádzajú najmä z mestských, kláštorných a hradných lokalít (Kunst/Galik 2000; Kyselý 2002; Pucher 1991; Vörös 2003). Najstaršie kosti sú datované do konca 15. a prvej polovice 16. stor. (Benecke 1994b, 381, tab. 51).

O výhodách moriek pri výtažnosti mäsa nemožno pochybovat. Má mohutné telo a niektoré jej formy dnes dosahujú hmotnost’ až 15-25 kg, čo pri odchove 50 mlád’at od jednej samice umožňuje získat aj 500 kg vysoko nutričného a pritom nízko energetického mäsa (Čuban/Kálal/Bureš 1955). Poskytujú i chutné

17 Rozmery os coracoideum (podla Bocheński/Campbell 2006, 60, obr. A2-II) z kláštora sú A = 76,19; B = 71,33; C = 9,81; E = (9,13); $\mathrm{D}=26,32 ; \mathrm{F}=18,95 ; \mathrm{G}=6,30$. Rozmery os coracoideum $\mathrm{z}$ hradu Gýmeš sú $\mathrm{E}=10,33 ; \mathrm{G}=8,05$.

18 Crawford $(1992,310,311)$ uvádza dátum najstaršej písomnej zmienky 24. október 1511, kedy na príkaz valencijského biskupa mala každá lod' prichádzajúca do španielskej Sevilly doviezt’ 10 živých vtákov. 
vajcia a kvalitné perie. Jej mäso predstavovalo nielen nový gurmánsky zážitok, ale spíňalo aj parametre pôstnej potraviny. V novoveku rýchlo preniklo do mestského, aristokratického a kláštorného jedálnička (Jeřábek 2004). Pod názvom „indická sliepka“, „indický kapún“ alebo „morský kohút“ sa však začala častejšie vyskytovat v uhorských urbároch až v druhej polovici 17. stor. (Duchoňová/Lengyelová 2016, 199). Historické pramene ukazujú, že väššie chovy sa udržiavali na majeroch Nádasdyovcov, Thökölyovcov, Rákoczyovcov, Thurzovcov a Zrínskych. Nové archeologické doklady ukazujú na chov/konzumáciu aj u Forgáčovcov (hrad Gýmeš) a v mníšskom prostredí (Zoborský kláštor).

\section{Divo žijúce cicavce}

Kosti divo žijúcich cicavcov sa v súbore vyskytujú sporadicky ( $\mathrm{n}=12=0,5 \% \mathrm{NISP})$. Identifikovali sme jeden terestriálny a dva semi-akvatické druhy (tabela 2). Kosti prvého boli určené ako plch sivý (Glis glis). V súbore je zastúpený dolnými čelustami a volným rezákom, azda i stehnovou kostou s neprirastenou dolnou epifýzou a kompletne zachovaným krčným stavcom, atlas (obr. 12: 1). Jedná sa o pôvodný, dnes vzácny druh listnatých a zmiešaných lesov hornatých regiónov Slovenska (Krištofík a i. 2012). Okrem lesa osídluje jaskynné, podzemné alebo záhradné biotopy. Má úzku, myši podobnú hlavu, zavalité telo a mäkký, pomerne hustý kožuch popolavej farby. Zviera hniezdi a zimuje najčastejšie v dutinách stromov, podzemných norách, jaskyniach, ale aj v ludských príbytkoch či maštaliach. Samica vrhá každoročne štyri mládaatá, ktoré sa osamostatňujú po prezimovaní (Krištofík a i. 2012, 65). Aj naše nálezy zo vzorky 12 (pivnica príbytku 9) reprezentujú nedospelých jedincov $(\mathrm{MNI}=2$ ). Hoci zachovalostou a sfarbením ich kosti korešpondujú s ostatnými nálezmi, nevykazujú stopy po ludských zásahoch. Domnievame sa preto, že aj ked' mohli byt’ súčasné, pravdepodobne prirodzene osídlili ruiny pivnice až po zániku kláštora. Zimujúce mlád’atá tu zrejme uhynuli bez pričinenia človeka. Hypoteticky však nemožno vylúčit ani scenár, ked’ sa mlád’atá plcha dostali do objektu počas fungovania príbytku. Treba spomenút i správy o využití plšieho či veveričieho mäsa v minulosti (napr. Poštulka 2011; Zíbrt 2012) a jeho anglický názov „edible dormouse“ alebo ,jedlá izbová myš“. Podla A. E. Brehma človek prenasledoval plcha pre mäso a kožu už v rímskom období (Beerden 2012; Brehm 1904-1905?). Biblia však zakazuje jest' "myši“" (Leviticus 11: 29$)^{19}$, a tak považujeme pôvod kostí mladých plchov v priestore pivnice za viac menej objasnený.

Na druhej strane kosti bobra a vydry ( $\mathrm{n}=9=0,4 \%$ NISP) jasne zapadajú do kontextu stravovania v kláštore (obr. 12: 2-4). Tieto druhy sú viazané na biotopy tečúcich alebo stojatých vôd a mokradí. I ked' vezmeme do úvahy existenciu rybníka v okolí kláštora, nepatria (na rozdiel od plcha) $k$ prirodzenej faune Zoborských lesov. Bobor aj vydra migrujú hlavne v rámci povodí rieky, no dokážu prežit aj v zajatí, preto mohli byṫ do kláštora dovezené živé. Ich chov však vylučujeme, hoci A. E. Brehm dobové pokusy podrobne opisuje: „,kníže Švarcenberg vystavil pár bobrů ještě na vídeňské výstavě světové, od té doby nepěstuje bobrů nikdo, ač jest to zaměstnání právě tak př̌ijemné jako vděčné. Že má ovšem pěstování bobrů také své potíze, toho dokladem jsou četné zkušenosti na témž panství. Proní pár bobrü usídlen byl v červeném dvoře r. 1773; za 6 roku činila rodina bobř́ 14, a za 10 let na to již 25 členư" (Brehm 1904-1905?, 85) alebo "vydry v útlém mládí z hnizda vybrané, mlékem a chlebem krmené, krotnou velice“; Brehm 1904-1905?, 477, 478).

Bobor eurázijský (Castor fiber) patrí medzi najväčšie európske hlodavce s dlžkou tela do $100 \mathrm{~cm}$ a hmotnostou až $30 \mathrm{~kg}$. Živí sa hlavne rastlinnou potravou a pletivami drevín, pričom preferuje víby a topole (Valachovič/Hanzelová/Špakulová 2012). Napriek obmedzeniam lovu (tzv. bobrovníci a strážci vôd $\mathrm{s}$ bobrami) bola jeho populácia značne zdevastovaná už v stredoveku. Na Slovensku bol lokálne vyhubený v 19. stor. pričom jeho výskyt dodnes pripomínajú názvy obcí, najmä na Liptove (Valachovič 2008). V súčasnosti opät osídluje vhodné biotopy dolných častí tokov riek a nevyhýba sa ani mestskému prostrediu (Valachovič/Hanzelová/Špakulová 2012, 84). Nedávno sa objavil aj v Nitre, na jazerách v mestskom parku. ${ }^{20}$ Vydra riečna (Lutra lutra) prirodzene osídluje riečne toky, mokrade a vodné plochy s dostatkom potravy. Domov jej poskytujú brehové rastlinné štruktúry, no prežíva napr. aj na povalách starých domov (Urban/Kadlečík/Kadleč́́ková 2012, 444). Podobne ako bobor sa vydra vyskytovala v minulosti na celom území Slovenska s výnimkou vrcholových častí vysokých pohorí. Dnes v nížinách takmer absentuje (Hlôška 2015). Už najstaršie lovecké zákony nariadovali jej hubenie, čo sa týkalo hlavne rybárov, ale aj špecializovaných lovcov vydier (Brehm 1904-1905?, 479). Rozsiahle zabíjanie bobrov a vydier kvôli kožušine, ale aj pôstnemu mäsu v povodí Hrona opisuje napríklad Matej Bel v práci Notitiae Hungariae Novae Historico-Geographica (Maliniak 2009, 179).

\footnotetext{
19 Biblia, Kniha Leviticus, Kapitola 11, 1-47.

20 http://nitra.dnes24.sk/foto-bobor-sa-udomacnil-v-mestskom-parku-na-sihoti-prezradili-ho-popadane-stromy-257553.
} 


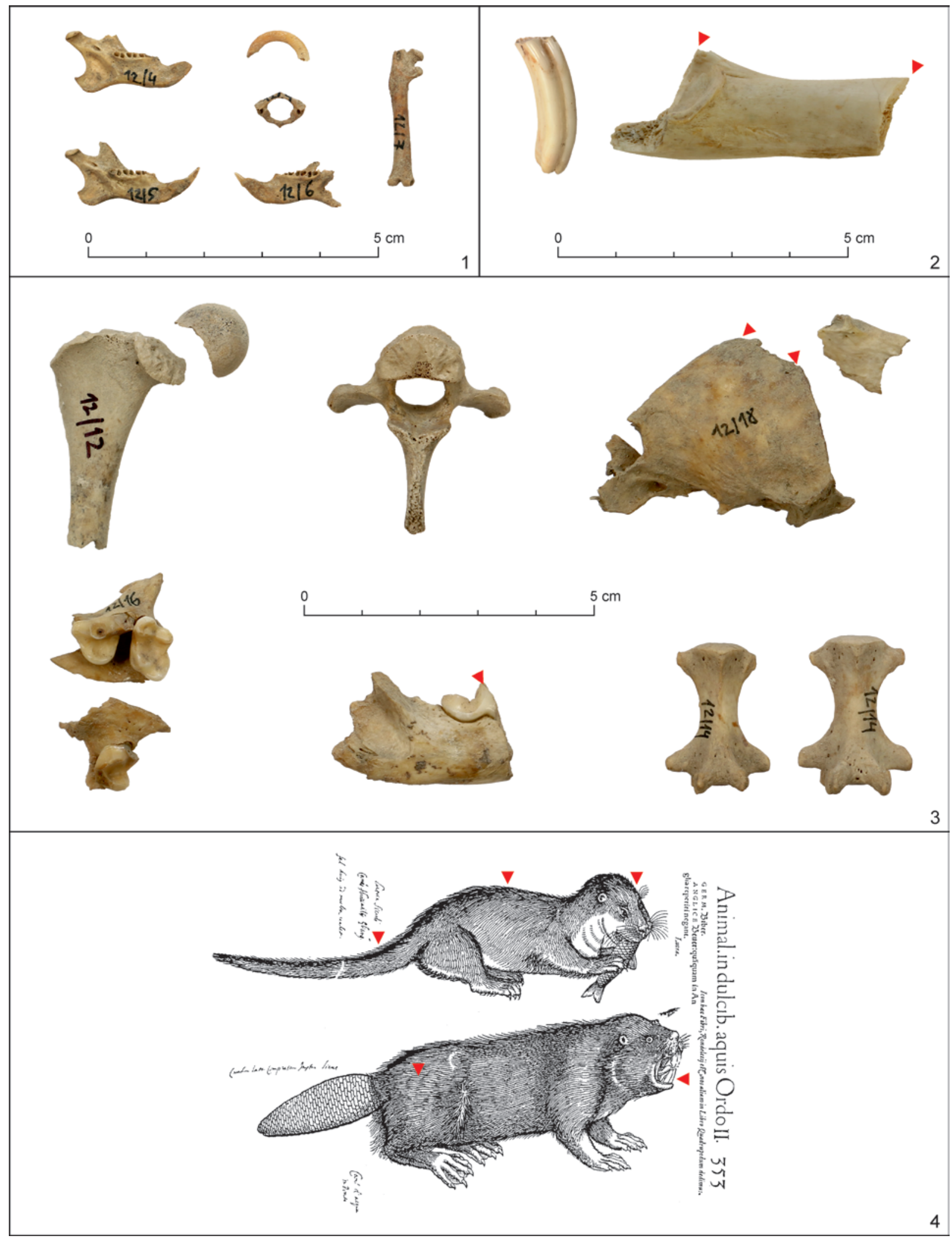

Obr. 12. Divo žijúce cicavce. 1 - plch sivý (Glis glis); 2 - rezák a čast’ rozseknutej panvovej kosti bobra eurázijského (Castor fiber) zo Zoborského kláštora; 3 - femur a stavec nedospelého jedinca a fragmenty neurokránia, hornej a dolnej čeluste, dvoch chvostových stavcov dospelého jedinca vydry riečnej (Lutra lutra) zo Zoborského kláštora; 4 - vydra a bobor na ilustrácii z Historiae Animalium (16. stor.) od Conrada Gessnera. Zdroj: http://dx.doi.org/10.3931/e-rara-1946 (upravené). Ludské zásahy vyznačené šípkou. Foto Z. Bielichová. 
V archeozoologických súboroch z obdobia novoveku doposial' kosti bobra a vydry absentovali (Bielich/Bielichová/Šimkovic 2018; Miklíková 2007; Miklíková/Fabiš 2004; Repka/Sater/Šimunková 2017; Šimunkovál Beljak Pažinová 2017; Vozák 2014; Vozák/Bielich, v tlačii). Kontext nálezov i intencionálne zásahy na kostiach ukazujú, že v súbore sa vyskytli v súvislosti s konzumáciou mäsa. Všetky zvyšky pochádzajú z interiéru príbytkov 3 a 9 (tabela 3). Nálezy zo vzorky 4 tvorí telo panvovej kosti (corpus ossis ischii $d x$.) a zub (molar sup./inf.), ktoré reprezentujú minimálne jedného, azda dospelého jedinca (obr. 12: 2). Telo panvovej kosti je na oboch koncoch preseknuté nástrojom s ostrou a azda tažšou čepelou, čo svedčí o porciovaní zadnej časti trupu. Kosti vydry zo vzorky 12 predstavujú pozostatky minimálne dvoch jedincov (obr. 12: 3). Nedospelú vydru (subadultus) reprezentuje proximálna čast’ stehnovej kosti s volnou epifýzou a pravdepodobne krčný alebo hrudný stavec s nezrasteným corpus vertebrae. Dospelého jedinca reprezentujú fragmenty lebky so zubami (parietale sin., maxilla et dens sin. et $d x$., mandibula et dens $d x$.) a dva chvostové stavce (vertebrae caudalis). Uvedené nálezy vykazujú len nejasné indície o možných zásahoch človeka staré zlomové línie na fragmentoch lebky a sánky, ktoré by mohli súvisiet’ s kuchynským spracovaním, prípadne samotnou konzumáciou vnútorného mozgového tkaniva a svaloviny jazyka.

V kontexte stredovekého a ranonovovekého stravovania sa považovalo mäso bobra, najmä z chvosta, za lahôdku i pôstne jedlo (Beranová 2007; Hlavačková 2015; Tomčík 2008). Uvádza sa, že mäso má najlepšiu chut' ak sa zviera kŕmi leknami (Brehm 1904-1905?, 80). Bobor ale poskytuje aj inak využitelné produkty: „úžitek, jehož bobři poskytují, vyváží téměř škodu jaké nadělají; kromě toho třeba uvážiti, že obývají bobřri nejraději krajiny neobydlené a že porážejí hlavně mlází, které opět záhy dorůstá a že zaplatí koží, masem a zvlášte bobřim strojem všecku škodu a vynahradí nad to mnohonásobně veškeré svizele a obtiže lovu" (Brehm 1904-1905?, 86). Tzv. bobrí stroj, castoreum, je výrazne páchnuci výlučok z podchvostovej žlazy, ktorým si bobor vytyčuje teritórium. Má tmavo červenohnedú až žltkastohnedú farbu, konzistenciu masti a horkú chut. Používal sa ako prostriedok na tíšenie kŕčov či pri výrobe parfumov (Baláž a i. 2013, 34). V liečitel'stve, ktorému sa venovali aj kamaldulskí mnísi, sa využíval aj bobrí tuk, krv, zuby a kosti, napr. pri bolestiach nôh. A. E. Brehm zhromaždil tiež zaujímavé dobové informácie o vydrách (Brehm 1904-1905?, 479-480). Najcennejšou bola ich koža, ktorú v 18. a 19. stor. predávali rybári. Z chlpov na chvoste sa zhotovovali maliarske štetce, z podsady klobúky. Krv, tuk a niektoré vnútornosti sa tiež používali v liečitel'stve. Mäso sa predávalo najmä do kláštorov ako oblúbený pôstny pokrm: „libra po zlatém, kdežto za dnešních dnů platí se sotva tretina, nebot vydrovina je t'ežce stravitelná a můze teprve rozličným uměním kuchařským učiniti se chutnou a záživnou" (Brehm 1904-1905, 497).

\section{Sladkovodné korytnačky}

Kosti korytnačiek tvoria velmi malú čast' hodnotených nálezov ( $\mathrm{n}=14=0,6 \%$ NISP). Pochádzajú z podláh príbytku 3, vzorky 1 a 2 (obr. 13: 1; tabela 3). Ide výlučne o elementy vnútornej kostry živočícha, čo nepochybne súvisí s odpadom jedla mníchov. Pancier bol odstránený už v kuchyni počas príprav zvierat na konzumáciu, a preto sa v materiáli jeho časti neobjavili. Vzorka 1 obsahovala kosti hornej končatiny a pletenca (scapula, coracoideum, humerus) a jedinú kosṫ dolnej končatiny (tibia). Sú to pravdepodobne zvyšky najmenej dvoch jedincov v dospelom, azda odlišnom veku (adultus?). Vzorka 2 zahŕňa pozostatky najmenej troch jedincov. Prítomné sú ramenné kosti (humerus), krčný stavec (vertebrae) a panvové kosti (pelvis). Títo jedinci boli zabití v odlišnom veku, čo naznačuje rozdielna vel'kost̉ i porézna štruktúra povrchu niektrorých kostí (nedospelý jedinec vo vekovej kategórii juvenis/subadultus). Presnejší vek korytnačiek možno odhadnút iba na základe kostených štítkov vypuklého panciera, tie však v súbore chýbajú. V sumáre bolo identifikovaných 14 fragmentov reprezentujúcich zvyšky minimálne štyroch jedincov. Kosti nevykazujú stopy hryzenia ani opálenia, niektoré však mohli byt zámerne rozlámané (prítomnost' "starých“ zlomov). Dôležitým dokladom ich kuchynského spracovania sú zásahy človeka registrované na štyroch ramenných kostiach. Na dvoch evidujeme zárezy (azda nožíkom) vedené priečne/šikmo cez diafýzu dlhej kosti poniže proximálnej epifýzy (vzorka 1). Prvá kost' bola rozdelená na dve polovice, pričom v súbore sa zachovala jej distálna čast'. Na druhej väčšej ramennej kosti evidujeme rez v oblasti proximálnej (priečne na os) a distálnej epifýzy (pozdížne), pravdepodobne dôsledok delenia končatiny v kíbe. Podobne umiestnené boli aj zárezy na tretej ramennej kosti zo vzorky 2 (obr. 13: 1). Je teda pravdepodobné, že telá korytnačiek boli porciované pred alebo v rámci tepelnej kuchynskej úpravy.

Sladkovodná korytnačka močiarna (Emys orbicularis) reprezentuje jediný pôvodný druh korytnačiek žijúcich na území Slovenska (obr. 13: 2). Patrí k menším druhom s dížkou panciera zvyčajne do 20, max. $30 \mathrm{~cm}$ (Oliva/Hrabě/Lác 1968, 321-323). Dožíva sa 120 rokov. Jej prirodzeným biotopom sú stojaté a mierne tečúce vody, zarastené slepé ramená riek, rybníky a jazerá. Druhotným stanoviskom môže byt’ 

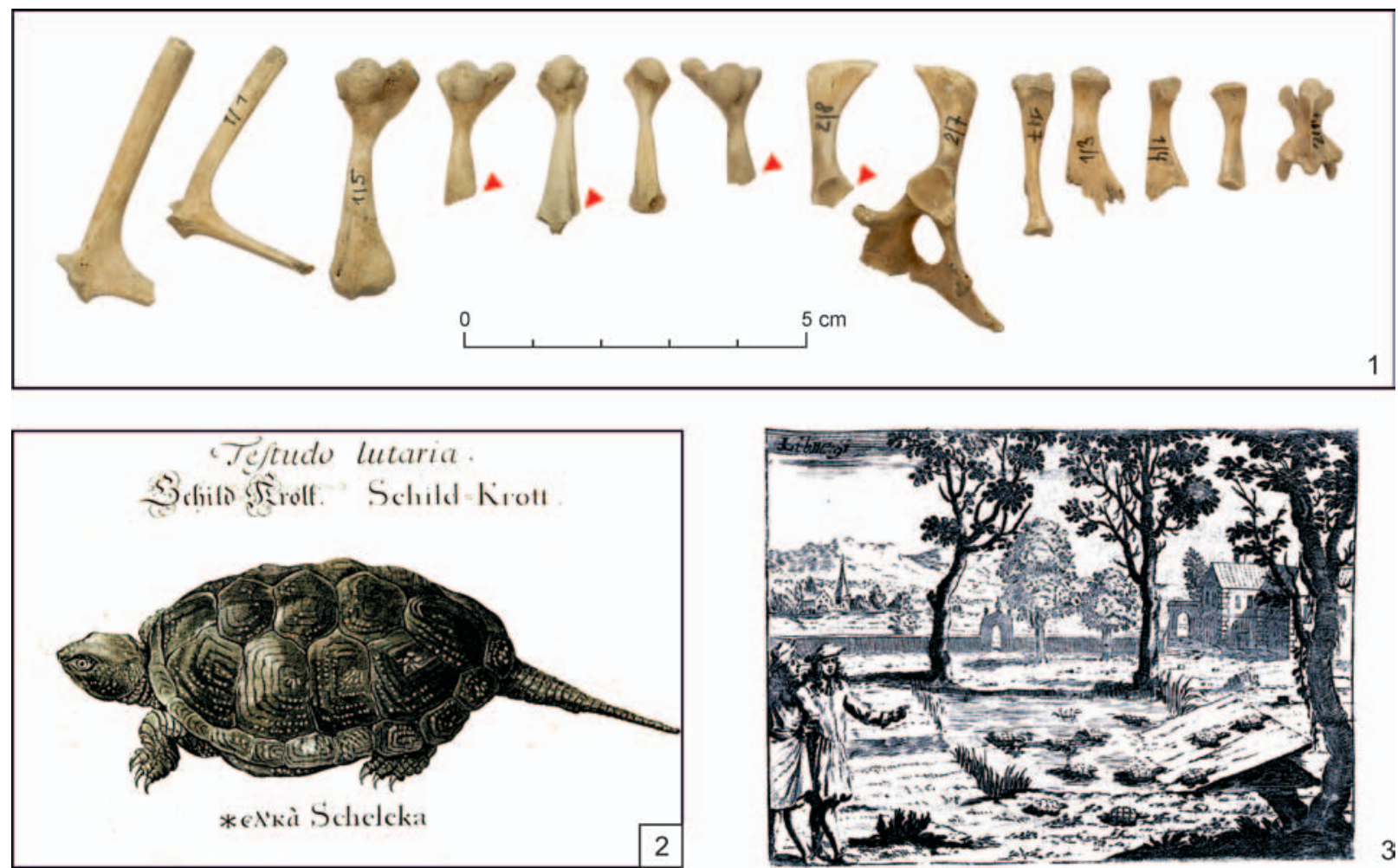

Obr. 13. Korytnačka močiarna (Emys orbicularis). 1 - kosti zo Zoborského kláštora z minimálne štyroch jedincov odlišnej vel'kosti a veku; 2 - korytnačka močiarna na ilustrácii z Danubius Pannonico-Mysticus (1726) od L. F. Marsigli, Zdroj: www.europeana.eu, upravené; 3 - chov korytnačiek na ilustrácii z Georgica curiosa (1682) od W. H. Hohberga, Zdroj: http://digital.bibliothek.uni-halle.de (upravené). Ludské zásahy vyznačené šípkou. Foto Z. Bielichová.

umelá vodná nádrž alebo rybník s bohatým zárastom, ktorý týmto plazom poskytuje úkryt a potravu. Často sa vyskytovala v inundačnom území riek, pričom ešte v druhej polovici 20. stor. je registrovaná aj v mŕtvych ramenách rieky Nitry (Bartová 2000; Čaputa/Holčík/Berger 1982; Kánya 2015; Randík a i. 1971). Dlhodobý výskyt v regióne potvrdzujú aj archeozoologické nálezy (Fabiš/Miklíková 2002). Ako každá korytnačka aj tento druh môže hladovat niekol'ko mesiacov, odchov nie je náročný. Hoci je mäsožravá, s oblubou konzumuje aj rastlinnú potravu a nepohrdne ani uhynutými živočíchmi. Držanie (chov?) živých korytnačiek mohlo prebiehat i v areáli Zoborského kláštora. Ich zimovanie v rybníku však muselo byṫ problematické, nakol'ko sú citlivé na mráz. Napriek tomu existujú zmienky, že tomu tak bolo, ba dokonca že chov korytnačiek bol zdrojom príjmov tunajšej rehole (neznámy autor 1939).

Poznatky o chove vodných korytnačiek v 17. a 18. stor. v Čechách zozbieral M. Záleský (1922; 1925). Venoval sa mu hlavne rod Schwarzerbergov "na Třeboňsku a Hlubocku ve zvláštních rybnících a dosti se rozmnožili i rozšírili " (Záleský 1927, 140). Za hlavné dôvody tohto typu akvakultúry možno považovat potrebu zabezpečenia pôstnej potraviny (obr. 13: 3). Do rovnakého obdobia spadajú i prvé pokusy chovu nepôvodných druhov, napr. korytnačky zelenkastej (Kunst/Gemel 2000; Záleský 1927). Podla niektorých autorov bola v Uhorsku korytnačka vel'mi rozšírená a na mnohých miestach aj prikrmovaná konským mäsom. Ako potravina sa vyvážala do Belgicka, Holandska i Anglicka (Bartová 2000, 204). Pod Karpatami ju nazývali „korytnica“ a podla povery ju držali v korytách s vodou pre ošípané, aby ich chránila pred chorobami. Cigánske obyvatel'stvo si z nej s oblubou pripravovalo polievku (Babor 1943). Historik Č. Zíbrt, autor diela Česká kuchyně za dob nedostatku před sto lety z roku 1917, príprave jej mäsa venoval náležitú pozornost’ a uvádza, že patrila medzi „oblíbené jídlo na měšt’anských a panských stolech" (Zíbrt 2012, 163-166). Opis usmrtenia a kuchynského spracovania plaza zahŕňa prikladanie žeravého železa alebo uhlia na pancier korytnačky, aby zviera vystrčilo hlavu, končatiny a chvost. Tie sa usekli (Zíbrt 2012, 163). S týmito fázami spracovania korytnačky by sa dali dat do súvisu aj nami registrované zásahy.

V kontexte archeozoologických nálezov z územia Slovenska ide o prvé evidentné doklady konzumácie korytnačiek (v Čechách napr. Kyselý a i. 2016). Najpočetnejšie doposial registrované kolekcie kostí 
korytnačiek pochádzajú práve z kláštorného prostredia, napr. z kartuziánskeho kláštora v rakúskom Mauerbachu (17. stor.). Tu sa okrem korytnačky močiarnej podarilo identifikovat aj zvyšky nepôvodného druhu, suchozemskej korytnačky zelenkastej (Testudo hermanni), ktorej mäso mnísi tiež konzumovali. Vysoká početnost nálezov ukázala, že práve korytnačky a ryby tvorili základ mäsitej potravy reholníkov (Galik/Kunst 2000; 2004; Kunst/Galik/Kroh 1999). Pomerne nízky počet nálezov tohto druhu v Zoborskom kláštore azda súvisí s menším rozsahom preskúmaných plôch na lokalite.

\section{Ryby}

Kosti rýb tvoria najväčšiu čast nálezov z kláštora na Zobore ( $\mathrm{n}=4824=91,5 \%$ NISP). S výnimkou dvoch fragmentov pochádzajú z interiéru mníšskych príbytkov, zo vzorky 1 ( $\mathrm{n}=266=9,2 \%$ NISP), vzorky $2(\mathrm{n}=330=1,2 \% \mathrm{NISP})$ a vzorky $12(\mathrm{n}=4226=81,2 \% \mathrm{NISP})$. Identifikovat' sa zatial' podarilo asi polovicu nálezov ( $\mathrm{n}=2608=67,6 \% \mathrm{NISP})$. V súbore sú zastúpené výlučne sladkovodné druhy rýb, a to jeseter (Acipenser sp.), kapor rybničný (Cyprinus carpio), jalec maloústy (Leuciscus leuciscus), belička európska (Alburnus alburnus), lieň sliznatý (Tinca tinca), sumec vel'ký (Silurus glanis) a štuka severná (Esox lucius). S výnimkou jalca reprezentujú tieto druhy hospodársky preferované ryby s výbornou kvalitou mäsa. Čast̉ nálezov ( $\mathrm{n}=580=24 \%$ NISP) zostala druhovo nešpecifikovaná a je zaradená do kategórie kaprovité ryby (Cyprinidae) a kapor alebo sumec (cf. Cyprinus/Silurus).

\section{Jeseter}

Jeseterovité ryby (Acipenseridae) patria medzi starobylé chrupkokostnaté ryby (Chondrostei), ktorých telo pokrýva pät radov skostnatených štítkov (obr. 14: 1). Jesetery (Acipenser sp.) sú tažné alebo polotažné ryby s paleoarktickým rozšírením, ktoré žijú pri dne no v čase neresenia tiahnu vyššie proti prúdu (Oliva/Hrabě/Lác 1968, 29-40). Sú to všežravce a dravce, ktoré dosahujú vysoký vek a značné rozmery. V slovenských riekach dnes trvalo žije iba jediný druh - jeseter malý (Acipenser ruthenus), no historické pramene dokladajú výskyt d’alších jeseterov, A. nudiventris, A. stellatus, A. gueldenstaedtii i najväčšej jeseterovitej ryby, vyzy (Huso huso). Zo sledovania zarybnenia rieky Nitry v 60. rokoch 20. stor. pochádza záznam o výskyte jesetera malého (A. ruthenus) a jesetera ruského (A. guldenstaedti; Sedlár 1969). Oba druhy sa podobajú vzhliadom, no A. guldenstaedti dorastá do väčšej dížky (priemerne $80-160$, max. 200-250 cm; 4-30, max. 100-130 kg) ako A. ruthenus (priemerne 40-60, max. 80-125 cm; 0,5-1,5, max. 3-17 kg). Archeozoologické nálezy jeseterov z územia Slovenska sú doposial’ výnimočné (Miklíková 2010), no tam kde ichtyoarcheologický výskum pokročil je doložená ich exploatácia od najstarších čias (Galik a i. 2015; Makowiecki 2003b). Neobmedzený rybolov spôsobil ich úbytok na Pobaltí už v 11.-12. stor. (Makowiecki 2003b, 196). Na slovenskom úseku Dunaja je výraznejšie zaznamenaný až v 16. stor. (Bartosiewicz/Bonsall 2008; Bartosiewicz/Bonsall/Şişu 2008; Hensel/Holčík 1997).

$\mathrm{V}$ súbore je zastúpený neidentifikovaný druh jesetera (Acipenser sp.) iba vo vzorke 12 (n = $23=$ $1 \%$ NISP). Zachované štítky z povrchu tela ryby sú na jednej strane hladké a na druhej výrazne granulované. Štyri exempláre pochádzajú z menšieho jedinca a/alebo druhu (obr. 14: 2). Ostatné sú výrazne väčšej vel'kosti a ich tvar napovedá, že reprezentujú ventrálne i laterálne štítky. Na upresnenie konkrétneho druhu jesetera však nateraz nedisponujeme relevantnou porovnávacou zbierkou. ${ }^{21}$ Predpokladáme zastúpenie najmenej dvoch jedincov $(\mathrm{MNI}=2)$. Väčšina štítkov je zachovaná vcelku (najväčší má priemer 40,7 mm), zvyšné predstavujú úlomky rozličnej vel'kosti. Na viacerých registrujeme ludské zásahy, priečne rezy paralelné alebo na viacerých častiach kosti, v jednom či viacerých smeroch (obr. 14: 3). Ide o dôsledky porciovania trupu rýb v kuchyni, hoci nemôžme vylúčit ani to, že takéto zásahy vznikli ešte v procese primárneho spracovania rýb v mieste odchytu, ilustrované napr. v diele „Danubius Pannonico-Mysticus“ od L. F. Marsigliho (1726). Tieto ryby poskytujú okrem mäsa i kvalitný „čierny“ kaviár. V. Tomčík uvádza, že: „rybie ikry tvorili zložku potravy tých najchudobnejších obyvatelov mesta, dokonca ich neraz vyhadzovali alebo použivali ako krmivo ošípané. Ich prednost’ou však bolo, že sa mohli konzumovat’ i v čase pôstu“ (Tomčík 2008, 14, 15). Výtažnost’ kaviáru bola najväčšia u obrovských výz a menšie jesetery sa cenili pre chutnejšie mäso (Bartosiewicz/Bonsall 2008). Kosti jeseterov sú preto časté v kláštornom prostredí (Kunst/Galik 2000). Ich výskyt v kláštore pod Zoborom možno hodnotił ako prejav gurmánstva a azda sezónnej (lokálnej?) dostupnosti. Nie

21 Stanovenie dížky tela jesetera na základe rozmerov štítku je problematické, nakol'ko ich morfológia sa rôzni aj v rámci tela jedinca a strany tela (viac Thieren/Van Neer 2016). 


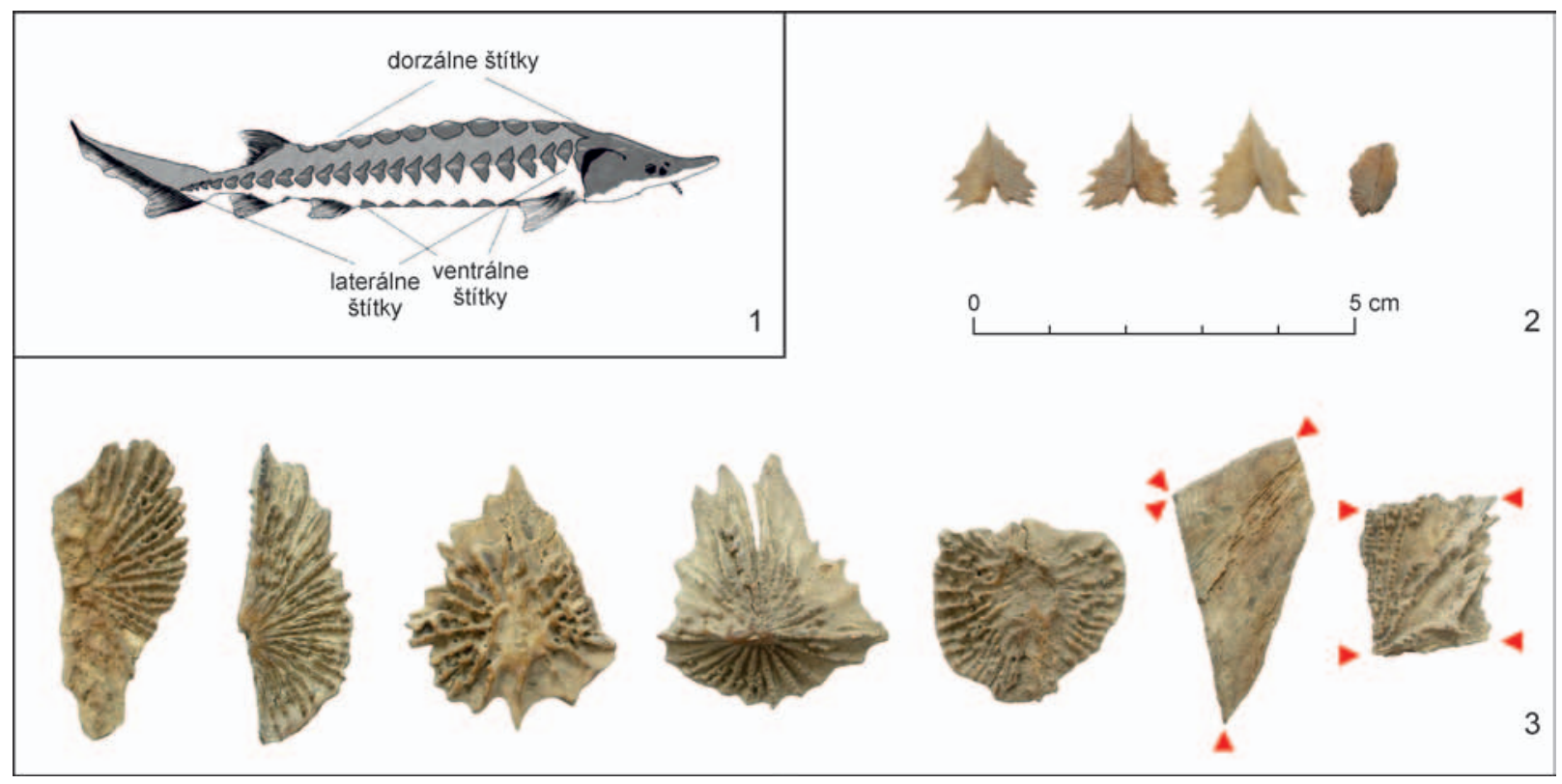

Obr. 14. Nitra-Zoborský kláštor. Jeseter (Acipenser sp.). 1 - schematické znázornenie lokalizácie radov kostených štítkov na tele ryby. Zdroj: Thieren/Van Neer 2016, 17, obr. 1, upravené; 2 - dorzálne štítky z malého jedinca; 3 - výber kompletne alebo čiastočne zachovaných štítkov z rôznych častí tela ryby. Ludské zásahy vyznačené šípkou. Foto Z. Bielichová.

je vylúčený ani vlastný odchov v rybníku. Výrazne nižšie zastúpenie kostí jesetera v súbore môže reflektovat̉ vyššiu cenu ryby, ale i celý rad biologických a tafonomických faktorov pôsobiacich na ich zachovanie v archeologickom kontexte. Absencia ostatných skeletových elementov, ktoré u jeseterov kostnatejú (napr. kosti hlavy)22 môže indikovat', že sa konzumovali sporadicky, azda sezónne.

\section{Štuka}

Dominantným druhom v materiáli je jednoznačne štuka $(n=893=36,9 \%$ NISP) i ked' podla minimálneho počtu jedincov je po kaprovi až druhou najčastejšie konzumovanou rybou $(\mathrm{MNI}=32)$. Štuka je dravá, stredne vel'ká až vel'ká ryba so širokým pyskom. Kým v dolnej čelusti má vel'ké ostré dozadu ohnuté zuby slúžiace k uchyteniu koristi (obr. 15: 1), medzičelust’ a zvyšok ústnej dutiny je posiaty početnými ostrými zúbkami. Tento druh má európske rozšírenie a prirodzene sa vyskytuje v jazerách, pri zarastených brehoch mrenového a pleskáčového pásma vrátane rieky Nitry (Sedlár 1969). Celkový tvar tela, vel'kost' i sfarbenie je ovplyvnené prostredím a ak je priaznivé, štuka je kratšia a zavalitejšia. Pri dostatku potravy rýchlo rastie a koncom prvého vegetačného obdobia dosahuje dĺžku 20 až $40 \mathrm{~cm}$. Maximá sa pohybujú v rozmedzí 100-150 cm a 12-35 kg (Oliva/HrabělLác 1968, 77). V tečúcich vodách Slovenska dosahuje v priemere 3-5 kg (Sedlár 1954), pričom vel'ké rozdiely vo vel'kosti boli zaznamenané aj v rámci jedného rybníku. Medzi štukami skonzumovanými v kláštore boli identifikované najčastejšie jedince s celkovou dížkou tela $30-40 \mathrm{~cm}$ a $40-50 \mathrm{~cm}$ (spolu n =84,4\%), čo je vel'kost', ktorú tieto ryby dosahujú vo veku 2-3 rokov (obr. 16: 1). Sú to jedince poniže súčasnej hospodárskej miery $60 \mathrm{~cm} \cdot{ }^{23}$ Vo veku 2 až 3 rokov štuka zvyčajne dosahuje hmotnost’ 100 až 1000 g (Sedlár 1954, 111) a takéto parametre mali i jedince konzumované v kláštore (tabela 7). V súbore sme identifikovali aj pät rozmerných (kaudálnych) stavcov, ktoré indikujú jedinca/jedincov s dížkou tela 90-110 cm a hmotnostou 7-11 kg.

Na rozdiel od jesetera má štuka zastúpené takmer všetky elementy kostry a ich početnost je pomerne vyvážená (tabela 8). Svedčí to o tom, že štuky sa do kláštornej kuchyne dostávali vcelku. V súbore prevažujú abdominálne stavce nad kaudálnymi, čo môže odrážat kulinárske a gastronomické preferencie mäsa z trupu. Ťažko identifikovatel’né elementy (napr. rebrá) u štuky chýbajú, no ich prezencia

22 U jeseterov kostnatejú len niektoré kosti hlavy a štítky, ktoré zvonka pokrývajú hlavu a trup tela. Ostatné elementy kostry (napr. stavce a rebrá) zostávajú počas celého života chrupavčité, a preto sa medzi archeologickými nálezmi nezachovajú.

23 Vyhláška 381/2018 Z. z. Ministerstva životného prostredia Slovenskej republiky z 29. novembra 2018, ktorou sa vykonáva zákon č. 216/2018 Z. z. o rybárstve, paragraf 12. 


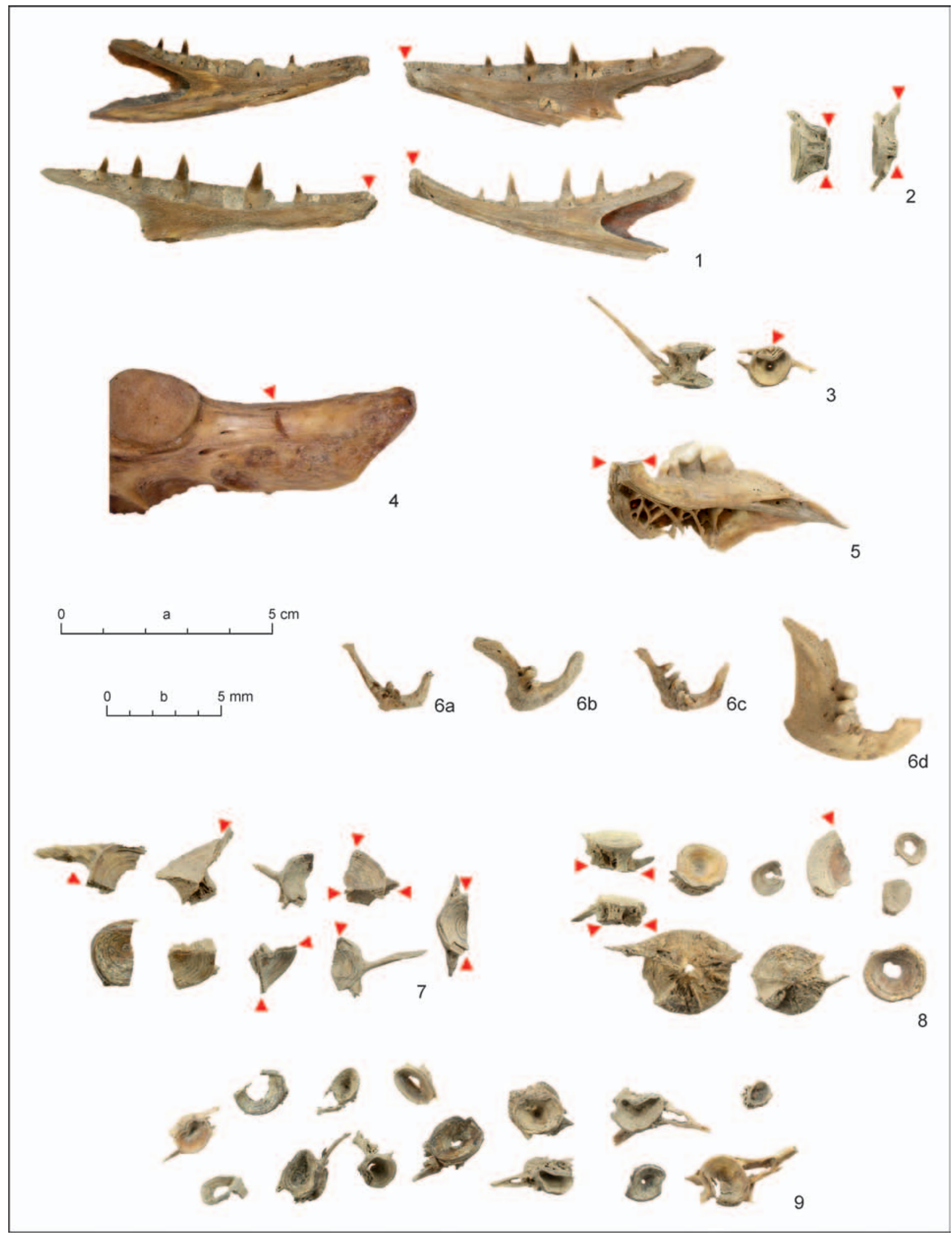

Obr. 15. Nitra-Zoborský kláštor. Štuka (Esox lucius) a kaprotvité druhy rýb (Cyprinidae). 1 - Esox lucius, dolná čel’ust’ (os dentale) vel'kých jedincov; 2 - Esox lucius, dva rozseknuté stavce v smere priečne na os tela ryby; 3 - Esox lucius, deformované stavce; 4 - Cyprinus carpio, detail na os hyomandibulare so zárezom; 5 - Cyprinus carpio, priečny rez os pharyngeale; 6-os pharyngeale so zuboradím, a - Alburnus alburnus; b - Tinca tinca; c - Leuciscus leuciscus; d - Cyprinus carpio; 7 - cf. Cyprinus/Silurus, stavce s rezmi pozdĺžne na os tela; 8 - cf. Cyprinus/Silurus, stavce s rezmi priečne na os tela; 9 - cf. Cyprinus/ Silurus, deformované stavce. Ludské zásahy (výberovo) vyznačené šípkou. Foto Z. Bielichová. Mierka: a -1-3, 5-9; b-4. 
Tabela 7. Nitra-Zoborský kláštor. Štatistické parametre konzumovaných rýb. Legenda: n - počet; TL - celková dížka tela; TW - celková hmotnost'.

\begin{tabular}{|c|c|c|c|c|c|c|c|c|}
\hline $\begin{array}{l}\text { Štatistické parametre } \\
\text { vel'kosti rýb }\end{array}$ & 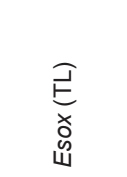 & 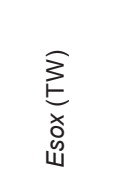 & 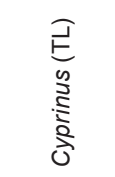 & 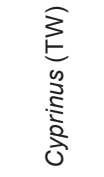 & $\begin{array}{l}\text { J } \\
\underset{\mathbb{E}}{\Xi} \\
\stackrel{\Xi}{E}\end{array}$ & $\begin{array}{l}\underset{\mathbb{Z}}{E} \\
\stackrel{\Xi}{E} \\
\stackrel{k}{E}\end{array}$ & 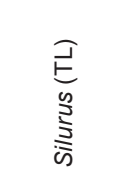 & 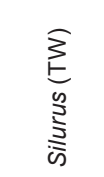 \\
\hline Aritmetický priemer & 43,016 & 0,744 & 42,390 & 1,689 & 26,028 & 0,231 & 95,288 & 10,640 \\
\hline Smerodajná chyba & 0,915 & 0,103 & 1,310 & 0,210 & 3,061 & 0,067 & 6,874 & 3,047 \\
\hline Medián & 40,317 & 0,439 & 38,967 & 0,904 & 27,210 & 0,229 & 93,470 & 5,516 \\
\hline Modus & 34,434 & 0,269 & 28,595 & 0,362 & - & - & - & - \\
\hline Smerodajná odchýlka & 12,030 & 1,358 & 15,665 & 2,516 & 6,845 & 0,150 & 45,595 & 20,213 \\
\hline Rozptyl & 144,728 & 1,844 & 245,379 & 6,332 & 46,851 & 0,022 & 2078,939 & 408,571 \\
\hline Rozpätie hodnôt & 82,281 & 10,727 & 92,722 & 19,200 & 16,329 & 0,351 & 225,894 & 123,021 \\
\hline Minimum & 27,472 & 0,131 & 16,938 & 0,077 & 16,789 & 0,056 & 38,244 & 0,381 \\
\hline Maximum & 109,753 & 10,858 & 109,660 & 19,277 & 33,119 & 0,406 & 264,138 & 123,401 \\
\hline Sum & 7441,773 & 128,642 & 6061,767 & 241,540 & 130,141 & 1,157 & 4192,686 & 468,164 \\
\hline $\mathrm{n}$ & 173 & 173 & 143 & 143 & 5 & 5 & 44 & 44 \\
\hline Koeficient spolahlivosti (95 \%) & 1,805 & 0,204 & 2,590 & 0,416 & 8,499 & 0,186 & 13,862 & 6,145 \\
\hline
\end{tabular}

v súbore je zaznamenaná. Vel’mi nízke zastúpenie majú aj kosti apendikulárneho skeletu, z oblasti medzi hlavou a trupom ryby, napríklad cleithrum, postcleithrum alebo scapulare. Hypoteticky by sa to dalo vysvetlit kuchynskými zásahmi, ktoré mohli najviac poškodit práve túto oblast̉ tela. $S$ najväčšou pravdepodobnostou sú kulinárskeho charakteru aj zárezy a záseky zdokumentované na ostatných častiach skeletu. Evidujeme najmenej 34 zasiahnutých kostí (obr. 15). ${ }^{24}$ Priečne (transverzálne) zárezy na piatich bližšie neurčených stavcoch sú jasným indikátorom delenia trupu ryby na väčšie či menšie porcie (obr. 15: 2). Iné priečne alebo šikmo orientované rezy boli zaznamenané na štyroch os dentale vel'kých rozmerov v oblasti symfýzy, t. j. spojenia dolnej čeluste v strednej mediálnej rovine tela (obr. 15: 1). Podobné modifikácie bývajú interpretované ako pozostatok snahy rybára vytiahnut hlboko prehltnutý a uviaznutý háčik (Wheeler/Jones 1989, 66). Ako alternatíva pripadá do úvahu tiež kuchynské spracovanie, napr. delenie hlavy. Nejasnej etiológie sú drobné zárezy, ktoré evidujeme na os supramaxillare a radi branchiostegi $(\mathrm{n}=2)$. Niektoré telá stavcov vykazujú umelé deformácie $(\mathrm{n}=7$; obr. $15: 3,9)$ a v literatúre sa spájajú so žuvaním potravy, ktorej odpad pochádzal zo sedimentov z fekálnych jám (por. Wheeler/Jones 1989, 75, obr. 5.2). Známky natrávenia, hryzenia (zvieratom/hlodavcom) či opálenia na kostiach štuky neregistrujeme.

\section{Kapor a kaprovité druhy rýb}

Kosti kaprovitých rýb (Cyprinidae) patria medzi druhé najfrekventovanejšie v súbore (n $=659=$ 27,2 \% NISP). Nachádzajú sa vo všetkých vzorkách s kostami rýb, pričom vo vzorke 1 počtom prevyšujú i štuku. Čast' Cyprinidae nebolo možné bližšie identifikovat' ( $\mathrm{n}=24=1 \% \mathrm{NISP}$ ). V súbore počtom nálezov dominuje kapor rybničný Cyprinus carpio ( $n=627=25,9 \%$ NISP). Na základe možnosti existencie rybníkov pod kláštorom predpokláme, že skôr ide o kosti rybničných, t. j. domestikovaných jedincov. Pôvodná divá forma má podlhovasté a nízke torpédovité telo. Na priereze je takmer okrúhle, zatial' čo rybničný kapor je charakteristický kratším a vysokým telom, často variabilne ošupeným. Prírodná dunajská forma, tzv. sazan, patrí ku kriticky ohrozeným druhom a na Slovensku už prakticky vyhynul. V minulom storočí však bol jeho výskyt zaznamenaný aj v rieke Nitre (Sedlár 1959). Rýchly rast, vysoká plodnost', dobré zužitkovanie potravy i nenáročnost̉ na životné prostredie predurčil tento druh pre chov v rybníkoch. Ichtyológ E. K. Balon (1995) kladie počiatky domestikácie dunajského kapra do doby rímskej

\footnotetext{
24 Počet modifikovaných kostí.
} 
Tabela 8. Nitra-Zoborský kláštor. Anatomická skladba v nálezoch kostí rýb (podl’a počtu).

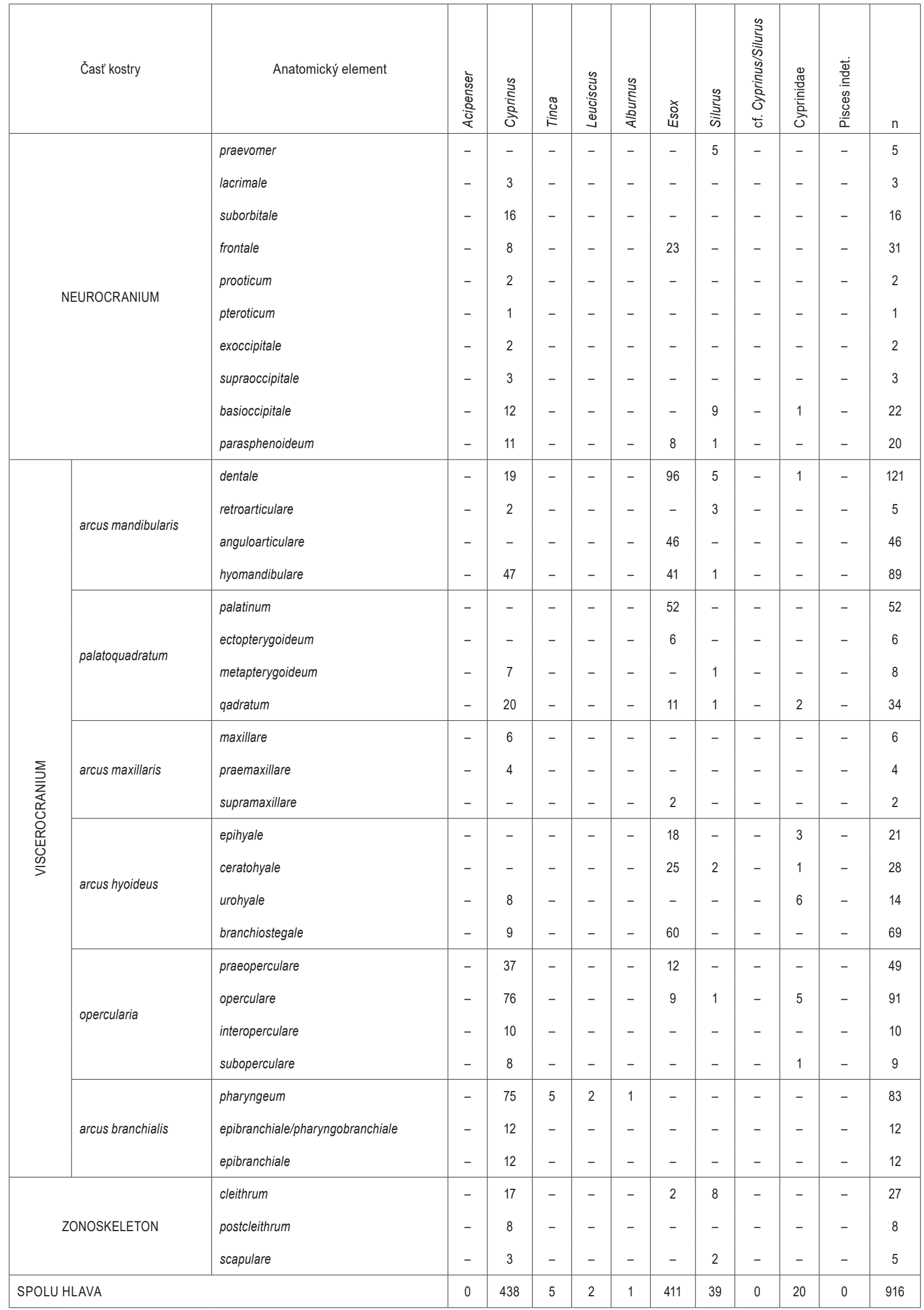


Tabela 8. Pokračovanie.

\begin{tabular}{|c|c|c|c|c|c|c|c|c|c|c|c|c|}
\hline Čast' kostry & Anatomický element & 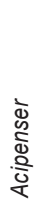 & 吝 & $\stackrel{\mathbb{E}}{\stackrel{5}{\leqslant}}$ & 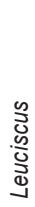 & 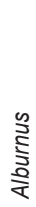 & $\begin{array}{l}\text { ò } \\
\text { w }\end{array}$ & 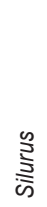 & 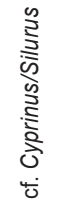 & 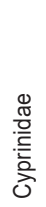 & 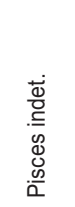 & $\mathrm{n}$ \\
\hline 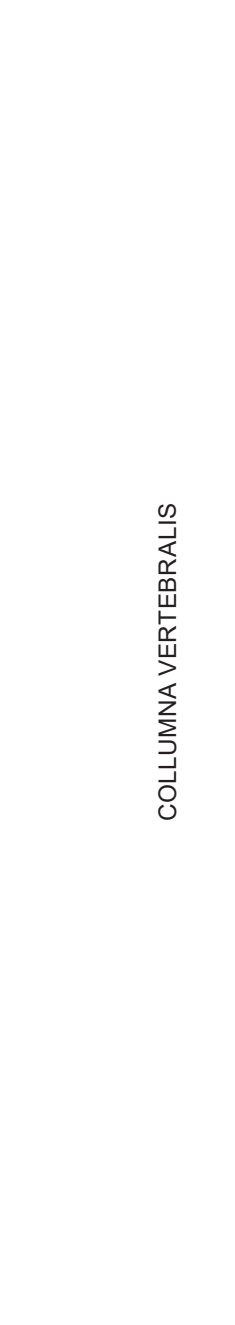 & $\begin{array}{l}\text { vertebrae cervicales } \\
\text { vertebrae thoracicae (1.) } \\
\text { vertebrae thoracicae (1.-5.) } \\
\text { vertebrae abdominales } \\
\text { vertebrae abdominales (?) } \\
\text { vertebrae abdominales (1.) } \\
\text { vertebrae abdominales (2.-5.) } \\
\text { vertebrae abdominales (3.) } \\
\text { vertebrae abdominales (7.-8.) } \\
\text { vertebrae abdominales (9.-10.) } \\
\text { vertebrae abdominales (12.-13.) } \\
\text { vertebrae abdominales (14.?) } \\
\text { vertebrae abdominales (14.-19.) } \\
\text { vertebrae abdominales (16.-18.) } \\
\text { vertebrae caudales/abdominales } \\
\text { vertebrae caudales } \\
\text { vertebrae } \\
\text { costa }\end{array}$ & $\begin{array}{l}- \\
- \\
- \\
- \\
- \\
- \\
- \\
- \\
- \\
- \\
- \\
- \\
- \\
- \\
- \\
-\end{array}$ & $\begin{array}{l}- \\
- \\
- \\
- \\
- \\
- \\
- \\
9 \\
- \\
- \\
- \\
- \\
- \\
- \\
- \\
- \\
-\end{array}$ & - & - & - & $\begin{array}{l}- \\
- \\
- \\
- \\
321 \\
- \\
- \\
- \\
- \\
- \\
- \\
- \\
- \\
- \\
- \\
- \\
- \\
- \\
- \\
- \\
-\end{array}$ & $\begin{array}{l}2 \\
- \\
7 \\
2 \\
1\end{array}$ & $\begin{array}{l}- \\
- \\
- \\
- \\
- \\
127 \\
137 \\
103 \\
- \\
- \\
-\end{array}$ & $\begin{array}{l}- \\
- \\
- \\
- \\
- \\
- \\
- \\
-\end{array}$ & 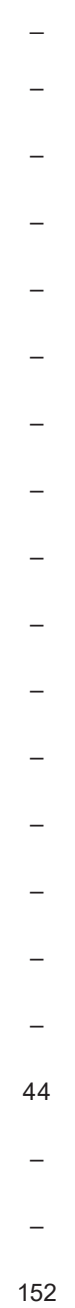 & $\begin{array}{c}2 \\
1 \\
2 \\
510 \\
7 \\
2 \\
1 \\
9 \\
3 \\
5 \\
2 \\
1 \\
3 \\
18 \\
18 \\
5 \\
183 \\
208 \\
\end{array}$ \\
\hline \multicolumn{2}{|l|}{ SPOLU TRUP } & 0 & 21 & 0 & 0 & 0 & 482 & 30 & 556 & 0 & 196 & 1285 \\
\hline 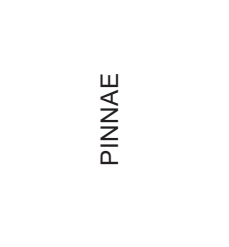 & $\begin{array}{l}\text { interspinale } \\
\text { interspinale/interhaemale } \\
\text { lepidotrich D3 } \\
\text { lepidotrich P1 }\end{array}$ & $\begin{array}{l}- \\
- \\
- \\
-\end{array}$ & $\begin{array}{l}20 \\
39 \\
8 \\
-\end{array}$ & - & - & - & $\begin{array}{l}- \\
- \\
- \\
-\end{array}$ & - & $\begin{array}{l}- \\
- \\
- \\
-\end{array}$ & $\begin{array}{l}- \\
- \\
-\end{array}$ & $\begin{array}{l}- \\
- \\
- \\
-\end{array}$ & $\begin{array}{l}20 \\
39 \\
8 \\
15\end{array}$ \\
\hline \multicolumn{2}{|l|}{ SPOLU PLUTVY } & 0 & 67 & 0 & 0 & 0 & 0 & 15 & 0 & 0 & 0 & 82 \\
\hline Iné & $\begin{array}{l}\text { scvama } \\
\text { tripus }\end{array}$ & $\begin{array}{l}23 \\
-\end{array}$ & $\begin{array}{l}- \\
10\end{array}$ & - & - & - & $\begin{array}{l}- \\
-\end{array}$ & - & $\begin{array}{l}- \\
-\end{array}$ & - & - & $\begin{array}{l}23 \\
10\end{array}$ \\
\hline Neurčené & & 0 & 91 & 0 & 0 & 0 & 0 & 1 & 0 & 4 & 2412 & 2508 \\
\hline SPOLU & & 23 & 627 & 5 & 2 & 1 & 893 & 85 & 556 & 24 & 2608 & 4824 \\
\hline
\end{tabular}



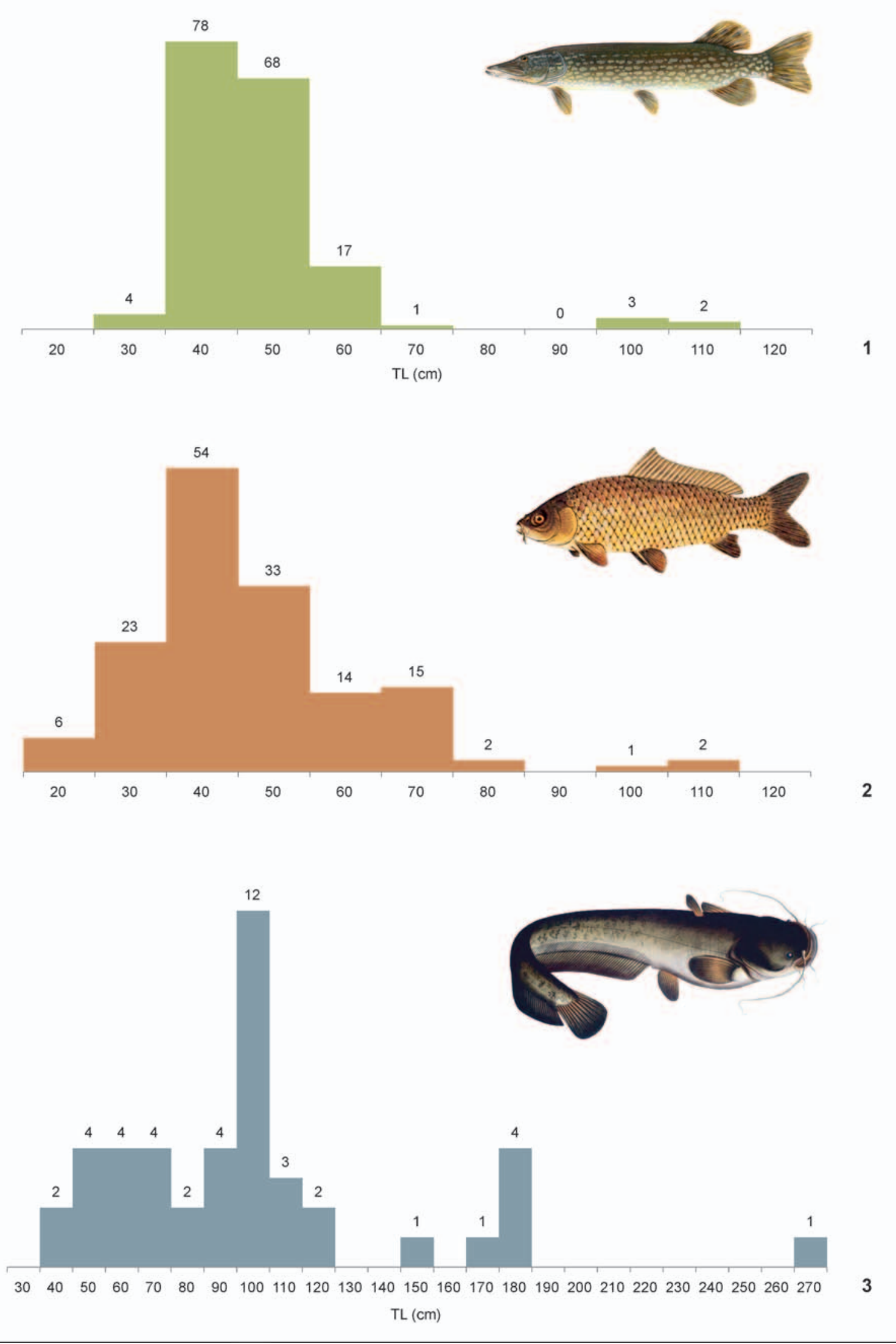

Obr. 16. Nitra-Zoborský kláštor. Vel'kost’ konzumovaných rýb (histogramy). 1 - Esox lucius (NISP = 173); 2 - Cyprinus carpio (NISP $=150) ; 3$ - Silurus glanis (NISP = 44). TL - celková dížka tela ryby vrátane chvosta. 
a spája ich s prítomnostou Rimanov na strednom Dunaji. Okrem širokej dostupnosti v záplavových zónach v čase neresenia za doklady počiatkov chovu kaprov na Slovensku považuje aj archeozoologické nálezy z rímskeho kastela Kelemantia v Iži. Na tieto tradície potom nadviazali krestania v stredoveku budovaním rybníkov (napr. Hoffman 1995).

Kapor je teplovodnou rybou a rast jeho tela závisí od teploty vody (vyžaduje asi $18-30{ }^{\circ} \mathrm{C}$ ). Pre umelý chov poskytujú optimálne podmienky eutrofné plytšie rybníky, ktoré sa dobre prehrievajú a disponujú dostatočnou vrstvou úrodného bahna na dne. V takých prípadoch nie sú vyše $20 \mathrm{~kg}$ jedince výnimkou. Súčasná lovná miera je $40 \mathrm{~cm}$. Meratelné kosti z kláštora poukazujú na preferovanie stredne velkých až vel'kých jedincov, s dížkou tela v rozmedzí 30-40 cm a 40-50 cm (obr. 16: 2; tabela 7). Prevažuje prvá vel'kostná kategória (36 \% NISP), čo môže, podobne ako u štuky, ukazovat na hospodársku selekciu rýb s cielom čo najväčšej výtažnosti mäsa. V priemere boli konzumované kapry dlhé $42,4 \mathrm{~cm}$ a vážili 1,7 kg. Takúto vel'kost' dosahujú rybničné kapry medzi druhým a tretím rokom života, v závislosti od príjmu potravy (Oliva/HrabělLác 1968, 154, 155). V súbore sa vyskytli aj zvyšky vel'kých kusov s dížkou tela 90-110 cm a max. hmotnostou približne 19 kg. Anatomické zastúpenie kostí kapra svedčí o prítomnosti všetkých skeletových elementov v súbore s výnimkou tažko identifikovatelných stavcov a rebier (tabela 8). Na rozdiel od štúk registrujeme u kaprov výraznejšiu prevahu kostí hlavy v porovnaní s ostatnými častami tela. Hoci toto skreslenie mohlo byt' spôsobené už exkaváciou a ponechaním istej časti materiálu na lokalite (pozri Materiál a metódy), súvisí pravdepodobne s problémami identifikácie stavcov a rebier. Tak ako pri štuke však možno konštatovat', že kapor sa do kláštornej kuchyne dostával vcelku najskôr živý. Mohlo íst’ o lokálne rybničné kapry či úlovky, ale aj jedince dopravené z väčšej vzdialenosti, nakol'ko kapry nie sú náročné na kyslík. Dobové pramene uvádzajú možnost’ skladovania živých jedincov vo vlhkom machu $\mathrm{v}$ pivniciach (Zeuner 1963, 481, 482).

Kulinárske úpravy kapra sme zdokumentovali len na niekol'kých kostiach hlavy a plutiev $(\mathrm{n}=7)$. Krátky drobný zárez nožíkom evidujeme na dvoch os hyomandibulare, v anatomickej oblasti arcus mandibularis (obr. 15: 4). Evidentný je aj priečny rez koncovej časti os pharyngeum (oblasṫ arcus branchialis) a rez cez os parasphenoideum (oblast’ neurocranium). Priečny rez cez proximálnu čast̉ tŕňa plutvy (interspinale), predelenie praeoperculare (oblast' opercularia) ako aj staré zlomy alebo poškodenia iných kostí na hlave ryby (najmä cleithrum, postcleithrum, operculum, praeoperculum) sú viac nejasné a definovanie príčin problematické (viac napr. Willis/Eren/Rick 2008). Vzhl’adom na kontext predpokladáme, že väčšina zachytených modifikácií súvisí s porciovaním väčších jedincov počas kuchynskej úpravy. Zaznamenaný bol evidentný rez cez pažerákovú kost’ u vel'kého kapra (obr. 15: 5) súvisiaci azda s porciovaním hlavy ryby. Početné boli zásahy na nerozlíšených kaprích/sumčích stavcoch (cf. Cyprinus/Silurus). Sledujeme jasné stopy po priečnych $(\mathrm{n}=22)$ a pozdlžnych $(\mathrm{n}=10)$ rezoch telom stavcov $(\mathrm{obr} .15: 7,8)$, pozostatky delenia trupu rýb na väčšie či menšie porcie mäsa. Značná čast’ stavcov $(n=80)$ vykazuje rozličné deformácie tvaru a obvodu artikulačných plôch, kompresie, zlomy, sploštenia, zvlnenia línií (obr. 15: 9), podobne ako u štuky. Na viacerých stavcoch sa tieto typy modifikácií vyskytujú spolu so zárezmi vedenými priečne na os tela stavca. Niektoré $\mathrm{z}$ deformovaných stavcov $(\mathrm{n}=12)$ vykazujú aj odlišnosti vo sfarbení, a to z maslovožltej na sivočiernu, makroskopicky však nevieme stanovit ich presnú príčinu. Môžu súvisiet s rôznymi tafonomickými faktormi, vrátane sfarbenia okolitého sedimentu. Ak by súviseli s úpravou jedla, v prípade sivo-čiernych stavcov by bolo mäso v okolí stavcov zuholnatené a teda znehodnotené (Lyman 1994, 385, 386). Úpravu niektorých porcií na otvorenom ohni ale nemožno vylúčit. Ako už bolo uvedené vyššie, niektoré práce dávajú deformácie tiel stavcov rýb do súvislosti s konzumáciou (prežúvanie) alebo prechodom cez tráviaci trakt cicavca vrátane človeka (Butler/Schroeder 1998; Jones 1984). Zostáva otázne, nakol'ko sa podobná interpretácia môže uplatnit pri väčších stavcoch.

Medzi ostatné druhy kaprovitých rýb, ktoré sa nachádzajú v súbore patrí lieň sliznatý (Tinca tinca), jalec maloústy (Leuciscus leuciscus) a belička európska (Alburnus alburnus). Registrujeme ich v minimálnom množstve ( $n=8=0,3 \%$ NISP), nakol'ko boli identifikované iba na základe pažerákovej kosti, ktorej morfológia a zuby patria medzi spol’ahlivé diagnostické znaky u Cyprinidae. Zatial čo pažeráková kost’ (os pharyngeale) má u kapra tri rady zubov, lieň má zuby jednoradové, jalec a belička dvojradové (obr. 15: $6 \mathrm{a}-\mathrm{d})$. Najpočetnejším druhom je lieň ( $\mathrm{n}=5=0,2 \% \mathrm{NISP})$. Ide o rybu so širokým európskym rozšírením, ktorá oblubuje tiché ramená a jazierka v inundácii s bahnistým dnom, stálou mäkkou vodnou vegetáciou. Bežne sa vyskytuje aj v povodí Nitry (Sedlár 1969) a po kaprovi ide o najbežnejšiu nedravú rybu vysádzanú do teplovodných rybníkov. Živí sa rovnakou potravou ako kapor. Hoci je lieň tolerantnejší k niektorým parametrom vody (kyslost', čistota), chýba mu jeho rastová schopnoste. Konzumnú váhu (250-300 g; 23-33 cm) dosahuje až v tretom roku (Sedlár 1954, 107, 108). Telo je dlhé $30 \mathrm{~cm}$, vzácne $70 \mathrm{~cm}$, vážiace 2 i viac kg (do 7,5kg; Oliva/Hrabě/Lác 1968, 106). Súčasná lovná miera je $30 \mathrm{~cm}$. Pažerákové zuby 
identifikované medzi nálezmi z pivnice príbytku ukazujú, že vel'kost štyroch jedincov skonzumovaných v kláštore sa pohybovala v rozmedzí $20-28 \mathrm{~cm}$ a $578-820 \mathrm{~g}$ (tabela 7). Lieň má velmi chutné mäso a menšie jedince nie je nutné pri spracovaní čistit od šupín. Tie sú totiž vel’mi drobné a tenké, pri tepelnom spracovaní sa rozpustia.

Ďalšie dva druhy predstavujú menej hospodársky významné kaprovité ryby a azda aj preto boli zachytené $\mathrm{v}$ zanedbatelnom počte (spolu $\mathrm{n}=3=0,1 \%$ NISP). V súčasnosti je jalec maloústy (Leuciscus leuciscus) niekde hojný, inde vzácny, pričom nebol registrovaný ani v rámci sledovania zarybnenia rieky Nitry (Sedlár 1969). Patrí medzi reofilné ${ }^{25}$ malé ryby s max. dížkou tela $20-25 \mathrm{~cm}$ a hmotnostou do $0,2 \mathrm{~kg}$. Považuje sa za sprievodný druh v akvakultúre (Oliva/HrabělLác 1968, 88-90). Nálezy dvoch pažerákových kostí naznačujú, že jedince z kláštora dosahovali dostatočnú konzumnú vel'kost̉ (odhad 19 a $21 \mathrm{~cm}$ ). Belička (Alburnus alburnus) je menšia ryba s pretiahnutým telom a je rozšírená vo všetkých slovenských riekach (Oliva/Hrabě/Lác 1968, 127-129). Jej telo je $15 \mathrm{~cm}$ dlhé, vzácne $17 \mathrm{~cm}$. Je najčastejšou obetou dravých druhov, najmä štuky a v rybolove sa používa ako nástražná rybka. Zo šupín beličky sa tiež získava umelá perlet' (essence d'Orient). Rozmery jedincov z kláštora zatial' nevieme presne stanovit', ale v porovnaní s ostatnými kaprovitými je zrejmé, že sa pohybovali v maximálnych hodnotách pre daný druh.

\section{Sumec}

Tretím najfrekventovanejším druhom ryby v súbore je sumec vel'ký Silurus glanis ( $\mathrm{n}=85=3,5 \%$ NISP). Je to vel'ká dravá ryba s telom bez šupín, ktorá po vyze predstavuje druhú najväčšiu rybu vôd Slovenska. Žije vo väčších riekach a priehradných jazerách v hlbokej vode pri dne, vo výmoloch, pod hatami. Živí sa menšími hospodársky nevýznamnými rybami, najmä beličkami (Oliva/HrabělLác 1968, 167-170). Dospelí sú všežraví. Neresí sa v apríli až júni v blízkosti brehov. Samice hniezda upravujú a samce po istý čas chránia ikry. Rozmnožuje sa i v umelých podmienkach, v rybníkoch (Sedlár 1954). Sumce dospievajú vo veku 4 až 5 rokov a pre vel'kú žravost̉ rýchlo rastú. Vo veku 20-30 rokov dosahujú dížku $2 \mathrm{~m}$ a hmotnost 40-60 kg. Jedince do $100 \mathrm{~kg}$ sú vzácnostou, no v minulosti tomu tak nebolo. Najvyššia známa hmotnost' sumca uloveného v Odre v roku 1761 je až $375 \mathrm{~kg}$ (Mohr 1957). Súčasná lovná miera je $70 \mathrm{~cm}$. Metrická analýza kostrových nálezov (obr. 16: 3; tabela 7) svedčí o tom, že v zoborskej kláštornej kuchyni sa spracovávalo mäso vel'kých jedincov s odhadovanou dížkou tela $80 \mathrm{~cm}$ a viac $(63,6 \%$ hodnotených kostí). V súbore nie sú ojedinelé ani staršie a mohutnejšie kusy s dížkou tela v rozmedzí $140-180 \mathrm{~cm}$ (n = 6). Unikátom je nález časti vomeru (obr. 17: 1), na základe ktorého možno odhadnút kapitálny úlovok či odchov sumca s dížkou tela $264 \mathrm{~cm}$ a hmotnostou $123 \mathrm{~kg}$. Ide o jedného z najväčších historicky zdokumentovaných sumcov v slovenských riekach vo veku približne 33-35 rokov (por. Hensel 2004). Hmotnostné parametre naznačujú, že konzumované jedince mali v priemere 10,6 kg (tabela 7). Mäso sumca je vel'mi chutné bez zbytočných drobných kostičiek, najmä pokial pochádza z l’ahších kusov do 5-6 kg (Sedlár 1954, 115). Vel'ká čast̉ kostí korešponduje s týmto kulinárskym poznatkom, indikujúc najväčšie zastúpenie jedincov v hmotnostnej kategórii 5-7 kg (41 \% zo 44 hodnotených).

U sumcov sledujeme vyrovnané zastúpenie elementov jednotlivých častí kostry, hlavy, trupu a plutiev (tabela 8). Podobne ako u štuky a kapra najväčšie skreslenie výsledkov spôsobujú nerozlíšené (cf. Cyprinus/Silurus) a neurčené stavce i rebrá (Pisces indet.). Prítomnost̉ kostí hlavy a plutiev indikuje, že sumce sa rovnako ako ostatné ryby dostávali do kuchyne celé, pravdepodobne čerstvé. Podobne však nevieme na základe makroskopického výskumu stanovit ich zdroj (rybničné sumce? prírodné?, dovoz?), no za predpokladu zachovania čerstvosti najskôr pochádzali z blízkeho okolia. Antropogénne zásahy registrujeme na všetkých častiach tela týchto rýb $(n=22)$. Najčastejšie ide o priečne a pozdľžne rezy/záseky cez centrum vertebralis u stavcov a pinna pectoralis P1 prsnej plutvy (obr. 17: 2). Azda súvisia so sekundárnym porciovaním trupu rýb na menšie časti, v prípade pinna pectoralis možno i oddelovaním prsnej plutvy a hlavy od trupu. Experimentálne práce potvrdzujú, že oba elementy patria spolu s rebrami k najčastejšie zasiahnutým v rámci kuchynského spracovania mäsa sumcov (Willis/Eren/Rick 2008). Pomerne často evidujeme priečne rezy cez os cleithrum ( $\mathrm{n}=4$; obr. 17: 3), ojedinele os operculare, ceratohyale alebo quadratum (n =1; obr. 17: 4-5). Lokalizácia týchto zásahov svedčí o porciovaní hlavy, príp. oddelovaní hlavy a trupu, najmä u vel'kých jedincov. Na jednej z os cleithrum sa nachádza aj umelý centrálne umiestnený otvor (obr. 17: 6, 7). Má nepravidelný okraj a radiálne zo stredu vychádzajúce zlomové línie. Čast’ úlomkov je vtla-

${ }^{25}$ Jeseter a jalec obyčajný patria k prúdomilným rybám (reofilné). Ostatné identifikované druhy rýb sú schopné prežívat’ a rozmnožovat' sa v rôznych biotopoch (eurytopné). Z pohl’adu rozmnožovania patria identifikované ryby k fytofilnej a fyto-litofilnej ekologickej skupine (Kirka 1997). 


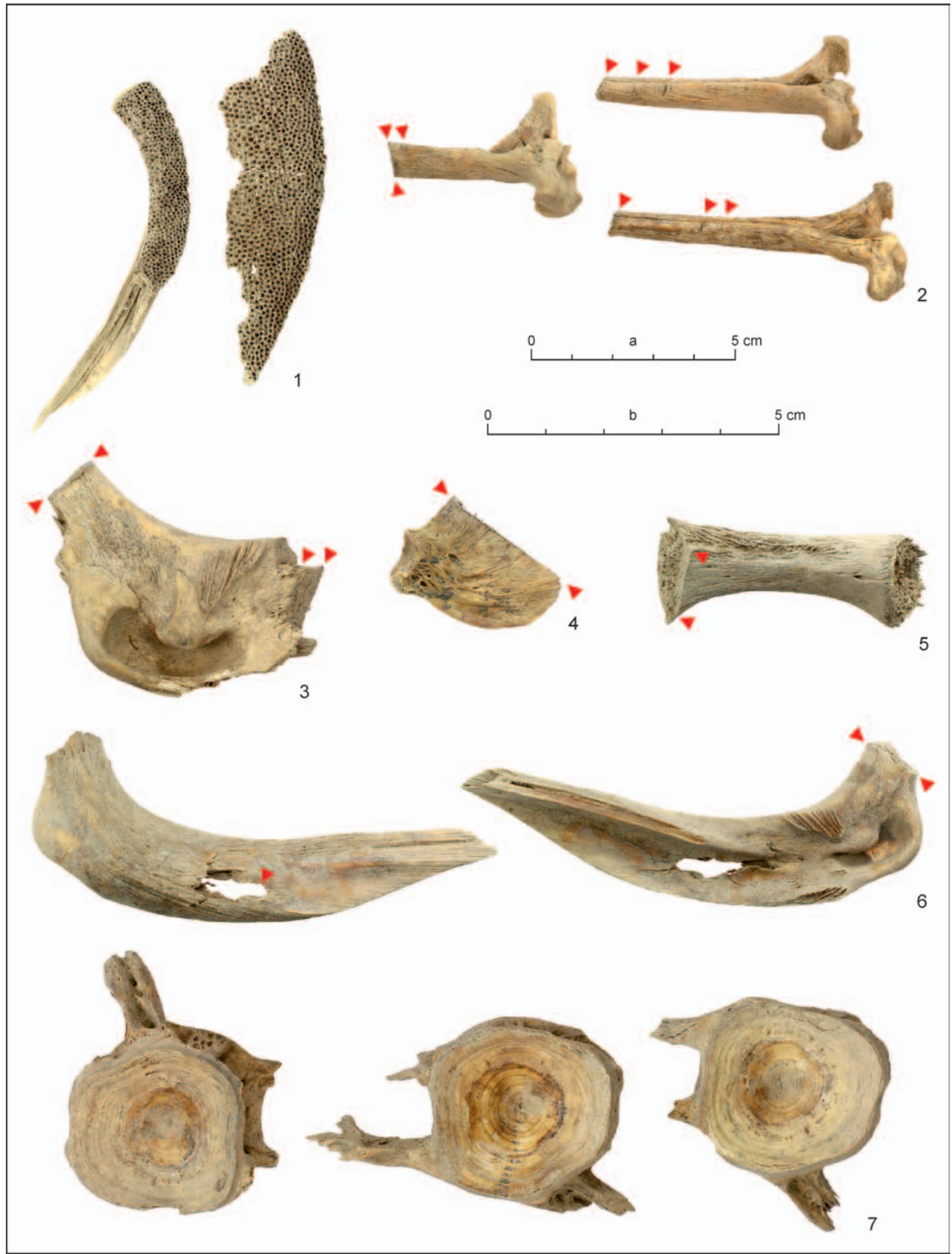

Obr. 17. Nitra-Zoborský kláštor. Sumec vel'ký (Silurus glanis). 1 - os dentale (vlavo) a fragment os vomere (vpravo); 2 - pinnae pectorales s mnohopočetnými zárezmi a odseknutými hrotmi; 3 - rozmerné os cleithrum s rezmi na oboch koncoch; 4 -os operculum; 5 - os ceratohyale; 6 - os cleithrum s umelým otvorom, ventrálny a dorzálny pohlad; 7 - tri vertebrae abdominales (asi 14.-19.) ryby s vel'kostou približne $175 \mathrm{~cm} / 35 \mathrm{~kg}$ a veku 17-18 rokov. L'udské zásahy vyznačené šípkou. Foto Z. Bielichová. Mierka: a-1, 3-7; b-2. 


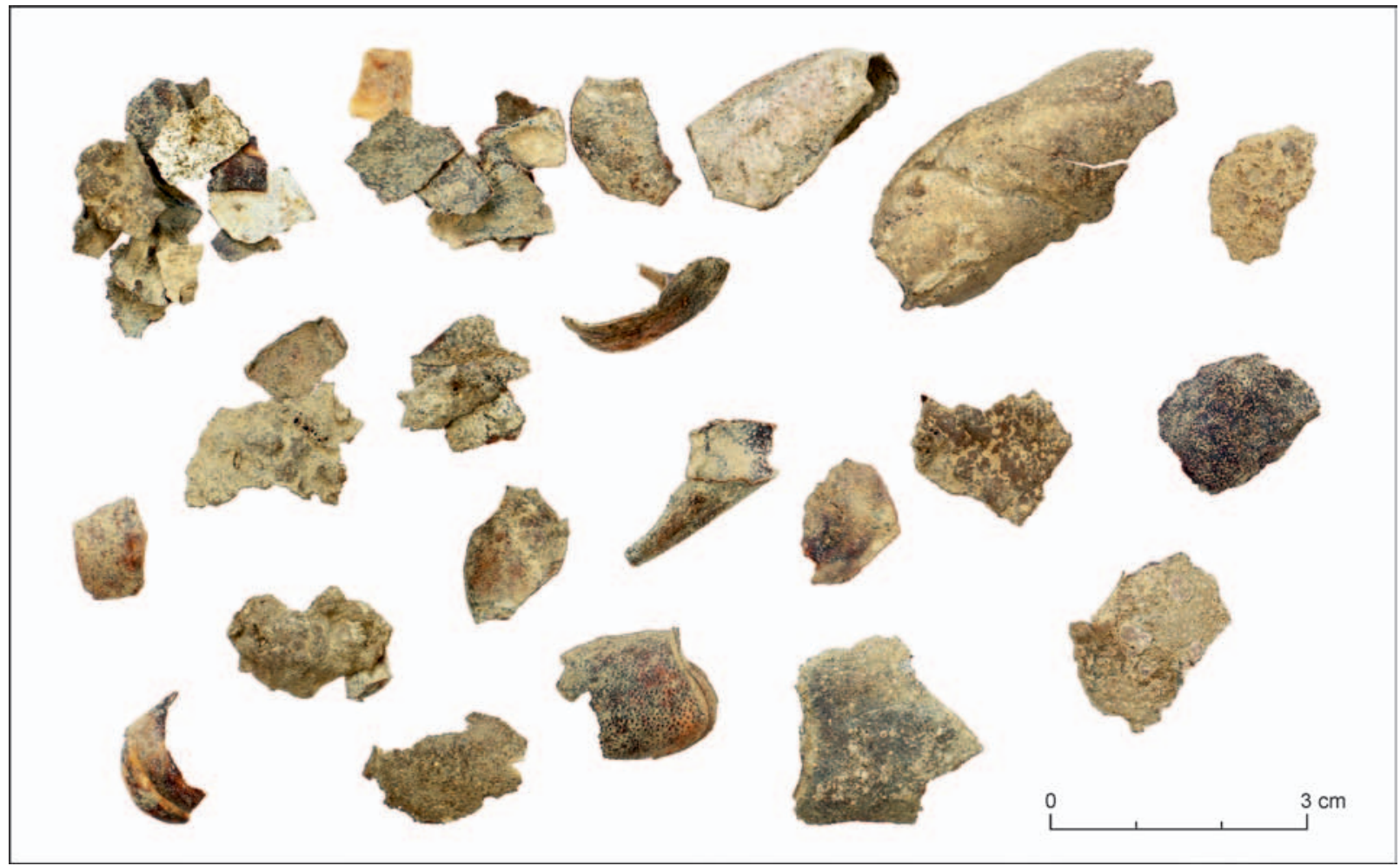

Obr. 18. Nitra-Zoborský kláštor. Fragmenty panciera klepiet, hlavohrude a bruška jedného alebo viacerých jedincov raka riečneho (cf. Astacus astacus). Foto Z. Bielichová.

čená smerom do vnútra hlavy ryby. Pokial' by išlo o zranenie počas života, kost̉ by vykazovala známky hojaceho procesu. Ich absencia ale svedčí o tom, že zásah bol spôsobený posmrtne, bud' počas lovu (ako dôsledok použitia bodavého rybárskeho náčinia používaného pri love v plytších vodách; Mjartan 1984), pri výlove ryby alebo počas kuchynských úprav. Sortiment zásahov doplňajú početné zárezy, registrované a opísané vyššie na nerozlíšených kaprích/sumčích stavcoch (obr. 15: 7-9).

\section{Raky a mäkkýše}

Medzi vzácne archeozoologické nálezy radíme zvyšky bezstavovcov, fragmenty vápenatých schránok tiel kôrovcov (Crustacea). Casti karapaxu pochádzajú výlučne zo vzorky 12 ( $n=45=1,9 \%$ NISP) a boli deponované v zásype pivnice spolu s riadom, rybami a kostami vydry. Reprezentujú predné končatiny (klepetá), hlavohrud' a bruško jedného alebo viacerých jedincov raka (obr. 18). I ked' fragmentárnost' zvyškov nedovoluje ich jednoznačné odlíšenie od iných autochtónnych druhov, raka bahenného (Astacus leptodactylus) a raka riavového (Austropotamobius torrentium; Kozák a i. 1998), predpokladáme, že zvyšky pochádzajú z raka riečneho (cf. Astacus astacus), nakolko v minulosti patril k najrozšírenejším (Novikmecl Svitok 2015; Stloukal/Vitázková/Janák 2013). Vo volnej prírode žije v tečúcich vodách a rybníkoch s bahnitým dnom. Patrí medzi najväčšie raky. Dorastá až do dížky $18 \mathrm{~cm}$ a dožíva sa 20 rokov. Najmä samci majú mohutné klepetá. Sfarbenie panciera je červenohnedé až čierne, no známe sú aj červené a modré varianty (Stloukal/VitázkoválJanák 2013, 234).

Historické a ojedinelé archeozoologické doklady svedčia o tom, že jemné mäso z rakov tvorilo súčast’ jedálnička človeka od najstarších čias (Patoka a i. 2014). V novoveku patril medzi sezónnu potravinu, najmä v období pôstu v kláštoroch (Beranová 2007; Stoličná-Mikolajová 2001). V oblube bol v kláštoroch, u bohatých meštanov a aristokracie (Duchoňová/Lengyelová 2016; Patoka/Kocánová/Kalous 2016; Pucher 1991). Vel'ký dopyt po tomto kôrovcovi, spolu s račím morom, dovezeným v 19. stor. zo severnej Ameriky, značne zredukoval ich populáciu v Európe i na Slovensku (napr. Stloukal 2008; Urban 2007). Zákaz chytania rakov pre ludové vrstvy Uhorska platil aj začiatkom 19. stor. (Botík/Slavkovský 1995, 101). Raky sa upravovali napr. dusené na smotane, v rizote, nákypoch alebo sa mäso mlelo aj do klobás (Tomč́k 2008, 
18). Nálezy z kláštora ukazujú na zastúpenie všetkých častí tela kôrovca, a tak možno predpokladat, že jedlo, servírované v príbytku 9, pozostávalo z celých rakov bez zbavenia schránok. Raky mohli mnísi zaobstarávat z lokálnych zdrojov, no mohli ich chovat aj v rybníku. Ottův slovník náučný z roku 1904 opisuje chov rakov ako špeciálnu odnož rybného hospodárstva, v rámci ktorého fungovalo v Čechách a na Morave až 468 fariem (Patoka/Kocánová/Kalous 2016, 4). Uvádza sa, že živočíchy exportovali živé alebo konzervované aj do zahraničia. ${ }^{26}$

Raky nachádzali široké uplatnenie v rámci pôstneho stravovania spolu s rybami, mäkkýšmi, korytnačkami alebo žabami, a to aj napriek tomu, že v biblii sa konzumácia kôrovcov neodporúča (Leviticus 11: 42)27. Presvedčivé doklady o konzumácii mäkkýšov zo Zobora zatial' materiál neposkytol, no vo vzorke 12 registrujeme i úlomky z ulity suchozemského slimáka. Náznak tmavých pásov na povrchu ulity naznačuje, že by mohlo íst’ o niektorý z druhov rodu Cepaea, s najväčšou pravdepodobnostou o pásikavca lesostepného Cepaea vindobonensis. Ide o xerotermný druh, prirodzenú súčast malakofauny Zobora a jeho predpolia (Ložek 1955, 337; Lučivjanská 1991). Vzhladom na nízky počet úlomkov i absenciu dokladov manipulácie človekom je pravdepodobné, že slimák sa dostal do deštrukcie pivnice náhodou. Nemožno ale vylúčit, že i mäkkýš tvoril súčast’ stravovania v kláštore, nakol'ko ich konzumácia i chov bol ešte v nedávnej dobe rozšírený (Čuban/Kálal/Bureš 1955). Recepty na úpravu slimačej svaloviny s príjemnou mäsitou chutou boli súčastou stravovania najmä v časoch núdze, dostupnosti alebo v rámci pôstu (napr. Zíbrt 2012).

\section{ZÁVER}

Analýza archeozoologických nálezov z výskumu kamaldulského kláštora sv. Jozefa (1693-1782) Zoborského kláštora priniesla nový pohlad do stravovania a sortimentu pôstnej stravy kamaldulskej rehole pôsobiacej pri Nitre na sklonku 17. a v 18. stor. V súbore boli zaznamenané prevažne zvyšky akvatických a semi-akvatických druhov zvierat - ryby, raky, vydra, bobor a korytnačka. V jedálničku reholníkov jednoznačne dominujú ryby o čom svedčia nálezy z jednoznačne datovaného (okolo 1760-1782) uzavretého kontextu - pivnice eremitky 9. Tento materiál poukazujú na prísne dodržiavanie svätej regule a dlhodobý príjem pôstnej stravy jej obyvatel’om. Zo živočíšnych potravín sme v konkrétnej eremitke zaznamenali okrem rýb konzumáciu mäsa vydry, kôrovcov, kury a vajec. Nálezy z výskumu eremitky 3 a jej blízkosti naopak naznačujú menej striedmu potravu. Okrem kostí rýb sa tu našli kosti korytnačky a bobra, ale i potraviny nesplňajúce regule kláštora - hovädzie, ovčie/kozie, bravčové a hydinové kosti so stopami kuchynského spracovania. Ich výskyt však vysvetlujú nálezové situácie z ktorých pochádzajú. Ide o vrstvy ktoré vznikli počas výstavby kamaldulského kláštora, resp. po jeho zániku a odrážajú prítomnost” „laikov“ v spomínaných obdobiach, teda medzi zánikom benediktínskeho kláštora (koniec 15. stor.) a začiatkom pôsobenia kamaldulských mníchov (1695). Je zrejmé, že aj počas niekol'ko rokov trvajúcej výstavby rozsiahleho areálu kláštora vzniklo mnoho odpadu zo stravovania, ktorý sa mohol dostat do vrstiev pod podlahami mniśskeho príbytku 3. Podobne po zrušení kláštora sv. Jozefa (1782), ked’ na lokalite existovala textilná manufaktúra a neskôr výletný hostinec, vznikol priestor na to, aby sa do rozpadávajúcich príbytkov dostali zvyšky "laickej“ stravy či kosti hospodárskych zvierat. Jednoznačné porušovanie prísnych pravidiel stravovania, o akom referujú písomné pramene z kláštora v Lechnici, teda na základe našich analýz nemožno konštatovat' (istým náznakom je kost’ kury z mníšskeho príbytku 9).

Nami uskutočnená taxonomická analýza ukázala, že v kláštore sa konzumovali len sladkovodné druhy rýb, najmä štuka, kapor a sumec, v menšej miere jeseter, lieň, jalec a belička. Do kuchyne sa najčastejšie dovážali alebo upravovali ekonomicky výhodné vel’ké jedince, ktoré naplňovali požiadavky na organizované stravovanie a adekvátny výtažok mäsa pre nasýtenie obyvatelov kláštora. Anatomická analýza získaného súboru svedčí o vyváženom podiele kostí hláv, trupu i plutiev rýb, čo značí, že do kuchyne sa dostávali vcelku, zrejme živé. Dočasné uskladnenie a prechovávanie v nádržiach na nádvorí hospodárskej budovy svedčí zachovaný plán kláštora. Žiadne stopy po upravovaní rýb konzerváciou, prípadne importe nepôvodných druhov sme v súbore neidentifikovali. V kuchyni sa porciovali a tepelne upravené sa servírovali do pustovníckych domčekov v rámci individuálneho stravovania (stopy porciovania, žuvania). Kláštor mohol ryby a ostatné potraviny pôstneho charakteru obstarávat nákupom,

\footnotetext{
26 Na Slovensku sa objavujú ojedinelé pokusy o oživenie tohto odvetvia rybného hospodárstva, naposledy pri obci Sebedražie. https://myhornanitra.sme.sk/c/6524657/pri-sebedrazi-otvorili-prvu-raciu-farmu-na-slovensku.html [11. 07. 2018].

27 Biblia, Kniha Leviticus, Kapitola 11.
} 
$\mathrm{v}$ rámci darov, ale aj prostredníctvom vlastného chovu v rybníkoch, o ktorých existencii pri areáli svedčí viacero dobových prameňov i pamät najstarších Zoborčanov (Točka 2017, 111). Zdá sa, že korytnačky a ryby chované v rybníkoch pod kláštorom, boli aj predmetom obchodu a príjmov Zoborského konventu (neznámy autor 1939, 202). Doteraz však presne nevieme ako intenzívne boli kamaldulskou reholou využívané. Identifikované jedince rýb, často vel’mi vel'kých rozmerov, sa skôr prihovárajú za nákup rýb. Nemôžeme však vylúčit ani odchov istého počtu väčších rýb v dobre obhospodarovanom rybníku, v priaznivých klimatických a hydrologických podmienkach. Je zrejmé, že bližší pohlad do tejto časti hospodárskych dejín kláštora môže poskytnút d’alší výskum archívnych prameňov.

\section{LITERATÚRA}

Babor 1943

Baláž a i. 2013

Balon 1995

Bartosiewicz 1990

Bartosiewicz/Bonsall 2008

Bartosiewicz/Bonsall/Şişu 2008

Bartová 2000

Beerden 2012

Benecke 1994a

Benecke $1994 b$

Beranová 2007

Bielich/Bielichová/Šimkovic 2018

Bocheński/Campbell 2006

Botík/Slavkovský 1995

Braje/Rick 2013

Branecký 1945

Brehm 1904-1905?

Brikhuizen 1989
F. Babor: Slovenská fauna. Slovenská vlastiveda I. Bratislava 1943.

I. Baláž/C. Ambros/F. Tulis/T. Veselovský/P. Klimant/T. Augustiničová: Hlodavce a hmyzožravce Slovenska. Nitra 2013.

E. K. Balon: The common carp, cyprinus carpio: its wild origin, domestication in aquaculture, and selection as colored nishikigoi. Guelph Ichthyology Reviews 3, 1995, $1-55$.

L. Bartosiewicz: Osteometric studies on the skeleton of pike (Esox lucius L. 1758). Aquacultura Hungarica 6, 1990, 25-34.

L. Bartosiewicz/C. Bonsall: Complementary taphonomies: Medieval sturgeons from Hungary. In: P. Béarez/S. Grouard/B. Clavel (ed.): Archéologie du poisson: 30 ans d'archéo-ichtyologie au CNRS. Hommage aux travaux de Jean Desse et de Nathalie Desse-Berset, XXVIIIe rencontres internationales d'archéologie et d'histoire d'Antibes. Éditions APDCA. Antibes 2008, 35-45.

L. Bartosiewicz/C. Bonsall/V. Şişu: Sturgeon fishing in the Middle and Lower Danube region. In: C. Bonsall/V. Boronean/I. Radovanovi (Eds): The Iron Gates in Prehistory: new perspectives. BAR International Series 1893. Oxford 2008, 39-54.

J. Bartová: Možnosti reštitúcie korytnačky močiarnej (Emys orbicularis) v prírodnej rezervácii Torozlín. Rosalia 15, 2000, 203-208.

K. Beerden: Roman dolia and the Fattenning of Dormice. Classical World 105, 2012, 227-235.

N. Benecke: Der Mensch und seine Haustiere. Die Geschichte einer jahrtausendealten Beziehung. Stuttgart 1994.

N. Benecke: Archäozoologische Studien zur Entwicklung der in Mitteleuropa und Südskandinavien von den Anfängen bis zum ausgehenden Mittelalter. Berlin 1994.

M. Beranová: Jídlo a pití v pravěku a ve š̌edověku. Praha 2007.

M. Bielich/Z. Bielichová/M. Šimkovic: Prvá sezóna archeologického výskumu na Plaveckom hrade v Malých Karpatoch. Zborník SNM 112. Archeológia 28, 2018, 243-255.

Z. M. Bocheński/K. E. Campbell Jr.: The extinct California Turkey, Meleagris californica, from Rancho la Brea. Comparative osteology and systematics. Contributions in Science 509, 2006, 1-92.

J. Botík/P. Slavkovský: Encyklopédia l’udovej kultúry Slovenska 2. Bratislava 1995.

T. J. Braje/T. C. Rick: From forest fires to fisheries management: anthropology, conservation biology, and historical ecology. Evol. Anthropology 22, 2013, 303-311. J. Branecký: Krátke dejiny zoborského kláštora a opátstva. Žilina 1945.

A. E. Brehm: Život zvierat. Cicavce. Podla Pechuel-Loesche/B. Bauše novo prepracovanom vydaní so stálym zretel’om ku krajinám českoslovanským“ upravenej prof. B. Baušem. Svazek I, II. Praha 1904-1905?

D. C. Brikhuizen: Ichthyo-archeologisch onderzoek: methoden en toepassing aan de hand van Romeins vismateriaal uit Velsen (PhD thesis, University of Groningen, Nederland). Groningen 1989.

\section{Pod'akovanie}

Ďakujeme M. Čurnému zo Šarišského múzea (Prešov) za spoluprácu pri príprave rukopisu a komentár ku kontextu analyzovaných vzoriek. M. Čurný a P. Jelínek z Archeologického múzea SNM (Bratislava) sa v roku 2003 podielali na výskume Zoborského kláštora a osteologickým nálezom venovali patričnú pozornost'. Naša vd’aka patrí R. Kyselému z Archeologického ústavu AV ČR (Praha) a T. Čejkovi z Centra biológie rastlín a biodiverzity SAV (Bratislava) za pomoc pri identifikácii kostí vtákov, hlodavcov a schránok mäkkýšov. Za preklad vybraných archívnych prameňov a literatúru dakujeme aj P. Prohászkovi z Archeologického ústavu SAV (Nitra). P. Ćerveňovi a L. Hurajtovej z Archeologického ústavu SAV (Nitra) patrí vd’aka za pomoc pri fotodokumentácii nálezov a zostavovaní obrazových príloh príspevku. 
Butler/Schroeder 1998

Crawford 1992

Cserenyei 1911

Čaputa/Holčík/Berger 1982

Čuban/Kálal/Bureš 1955

Driesch 1976

Duchoňová/Lengyelová 2016

Eliaš 2010

Fabiš/Miklíková 2002

Galik/Kunst 2000

Galik/Kunst 2004

Galik a i. 2015

Gentry/Clutton-Brock/Groves 2004

Grau-Sologestoa 2016

Habovštiak 1966

Habovštiak 1971

Hamminger 1986

Hensel 2004

Hensel/Holčík 1997

Hlavačková 2015

Hlôška 2015

Hoffman 1995

Hoffman 2005

Choyke/Jaritz 2017

Jeřábek 2004

Jones 1984

Judák 1997

Judák 2009

Kánya 2015
V. L. Butler/R. A. Schroeder: Do digestive processes leave diagnostic traces on fish bones? Journal of Archaeological Science 25, 1998, 957-971.

R. D. Crawford: Introduction to Europe and diffusion of domesticated turkeys from the America. Archivos de zootecnia 41 (extra), 1992, 307-314.

Š. Cserenyei: Príspevok k dejinám nitrianskych kamaldulov. Religio, 1911, 423, 424, 439, 440.

A. Čaputa/J. Holčík/Z. Berger: Atlas chránených vodných živočíchov Slovenska. Bratislava 1982.

S. Čuban/V. Kálal/J. Bureš: Chov zvierat. Chov malých hospodárskych zvierat. Bratislava 1955.

A. von den Driesch: A guide to the measurement of animal bones from archaeological sites. Peabody Museum bulletins 1. Harvard 1976.

D. Duchoňová/T. Lengyelová: Hradné kuchyne a šlachtické stravovanie v ranom novoveku. Radosti slávností, strasti každodennosti. Bratislava 2016.

M. Eliaš: Forgáchovci. Šlachtický rod z Gýmeša. Trenčín 2010.

M. Fabiš/Z. Miklíková: Nálezy korytnačky močiarnej (Emys orbicularis L.) v archeofaunálnych zvyškoch z Nitry a okolia. Rosalia 16, 2002, 155-160.

A. Galik/G. K. Kunst: Weitere Tierknochenuntersuchungen in der Kartause Mauerbach. Fundberichte aus Österreich 38, 2000, 409-412.

A. Galik/G. K. Kunst: Dietary habits of a monastic community as indicated by animal bne remains from Early Modern Age in Austria. In: S. J. O’Day/W. Van Neer A. Ervynck (ed.): Behaviour Behind Bones: the Zooarchaeology of Ritual, Religion, Status and Identity. Oxford 2003, 224-232.

A. Galik/G. Haivog1/L. Bartosiewicz/G. Guti/M. Jungwirth: Fish remains as a source to reconstruct long-term changes of fish communities in the Austrian and Hungarian Danube. Aquatic Sciences 77, 2015, 337-354.

A. Gentry/J. Clutton-Brock/C. P. Groves: The naming of wild animal species and their domestic derivates. Journal of Archaeological Science 31, 2004, 645-651.

I. Grau-Sologestoa: Socio-economic status and religious identity in medieval Iberia: The zooarchaeological evidence. Environmental Archaeology 22, 2016, 189-199.

A. Habovštiak: Záchranný výskum pri bývalom kláštore $\mathrm{v}$ Nitre na Zobore. Študijné zvesti AÚ SAV 14, 1966, 227-233.

A. Habovštiak: Stredoveké nálezy a pozostatky kamenného vodovodu pri bývalom Zoborskom kláštore. Zborník SNM 65. História 11, 1971, 97-119.

J. D. Hamminger: Leopoldi Capelln am Kallenberg oder St. Josephskirche der PP Kamaldulenser auf dem Josephsberg? Wo hat Pater Marco d'Aviano vor d. Entscheidungsschlacht am 12. Sept. 1683 die heilige Messe gefeiert? Wien 1986.

K. Hensel: Find of capital wels catfish Silurus glanis (Actinopterygii: Siluridae) in excavations of a Roman military fort in Southern Slovakia. Biologia 59. Supplementum 15. Bratislava 2004, 191-203.

K. Hensel/J. Holčík: Past and current status of sturgeons in the upper and middle Danube River. Environmental Biology of Fishes 48, 1997, 185-200.

M. Hlavačková: Ryby a pôstna tradícia. In: D. Dvořáková a kol. (ed.): Človek a svet zvierat $v$ stredoveku. Bratislava 2015, 447-460.

L. Hlôška: Vydra riečna Lutra lutra (Linnaeus, 1758). In: M. Janák/J. Černecký/ A. Saxa (ed.): Monitoring živočíchov európskeho významu v Slovenskej republike. Výsledky a hodnotenie za roky 2013-2015. Banská Bystrica 2015, 294-295.

R. C. Hoffman: Environmental change and the culture of common carp in medieval Europe. Guelph Ichtyology Reviews 3, 1995, 57-85.

R. Hoffman: A brief history of aquatic resource use in medieval Europe. Helgolad Marine Research 59, 2005, 22-30.

A. M. Choyke/G. Jaritz (ed.): Animaltown: Beasts in Medieval Urban Space. BAR International Series 2858. Oxford 2017.

A. F. Jeřábek: Klášterní kuchařka aneb Oroduj za nás, domácí kuchař. Praha 2004.

A. K. G. Jones: Some effects of the mammalian digestive szstem on fish bones. In: N. Desse-Berset (ed.): $2^{\text {nd }}$ fish osteoarchaeology meeting, CNRS. Centre de recherches archéologiques. Notes et Monographies Techniques 16. Paris 1984, 6-65.

V. Judák: Pôsobenie kamaldulov na území Slovenska. In: J. Dorula (ed.): O prekladoch Biblie do slovenčiny a do iných slovanských jazykov. Bratislava 1997, 71-83.

V. Judák: Pôsobenie kamaldulov na Zobore a na celom území Slovenska. Monumentorum tutela 21, 2009, 17-28.

M. Kánya: Korytnačka močiarna Emys orbicularis (Linaeus, 1768). In: M. Janák/ J. Černecký/A. Saxa (ed.): Monitoring živočíchov európskeho významu v Slovenskej republike. Výsledky a hodnotenie za roky 2013-2015. Banská Bystrica 2015, 202, 203. 
Kirka 1997

Kompánek 1895

Kozák a i. 1998

Kraskovská 1942-1943

Krištofík a i. 2012

Kunst/Galik 2000

Kunst/Galik/Kroh 1999

Kunst/Gemel 2000

Kyselý 2002

Kyselý 2005

Kyselýa i. 2016

Lacko 1965

Lacko 1967

Lepiksaar 1983

Libois/Hallet-Libois 1988

Lombardini 1895

Lorenz 1991

Ložek 1955

Lučivjanská 1991

Lyman 1994

Makowieczki 2003a

Makowiecki 2003b

Maliniak 2009

Marsigli 1726

Miklíková 2007

Miklíková 2010

Miklíková/Fabiš 2004

Mikloško 2012

Mjartan 1984

Mohr 1957

Morales/Rosenlund 1979

Moreno-García/Detry 2010
A. Kirka: Atlas rýb vodného diela Gabčíkovo. Bratislava 1997.

J. Kompánek: Nitra. Nástin dejepisný, miestopisný a vzdelanostný. Tovaryšstvo 2, 1895, 54-114.

P. Kozák/J. Pokorný/T. Policar/J. Kouřil: Základní morfologické znaky k rozlišení raků $v$ ČR. Vodňany 1998.

L. Kraskovská: Archeologický výskum na Zobore pri Nitre. Sborník SNM 36-37, 217-227.

J. Krištofík/P. Fend’a/V. Hanzelyová/M. Stanko/M. Špakulová: Plch sivý - Glis glis. In: J. Krištofík/Š. Danko (ed.): Cicavce Slovenska - rozšírenie, bionómia a ochrana. Bratislava 2012, 76-81.

G. K. Kunst/A. Galik: Essen und Fasten in mittelalterlichen Klostern aus archäozoologischer Sicht. In: H. Adler (ed.): Fundort Kloster - Archäologie im Klösterreich. Fundberichte aus Österreich Materialhefte A 8. Wien 2000, 246-258.

G. K. Kunst/A. Galik/A. Kroh: Reste von Fastentieren und andere bemerkugsweret Tierreste aus der Kartause Mauerbach. Fundberichte aus Österreich 37, 1999, 397-402. G. K. Kunst/R. Gemel: Zur Kulturgeschichte der Schildkröten unter besonderer Berücksichtigung der Bedeutung der Europäischen Sumpfschildkröte, Emys orbicularis (L.) in Österreich. Stapfia 69, 2000, 21-62.

R. Kyselý: Archeozoologický rozbor osteologického materiálu z Náměstí republiky ze sondy 15 (1. polovina 17. století) z areálu bývalých kasáren Jiř́iho z poděbrad na Náměstí republiky v Praze 1 (zjištovací výzkum v letech 1998-1999). Archaeologica Pragensia 16, 2002, 197-216.

R. Kyselý: Archeologické doklady divokých savců na území ČR v období od neolitu po novověk. Lynx 36, 2005, 55-101.

R. Kyselý/K. Čuláková/M. Pecinovská/P. Široký: European Pond Turtles from Obříství (Bohemia, Czech Republic). International Journal of Osteoarchaeology 26, 2016, 732-739.

M. Lacko: Camaldulese Hermits in Slovakia (Zobor, Červený kláštor). Slovak studies 5, 1965, 99-204.

M. Lacko: Kamalduli na Slovensku (Zobor, Červený kláštor). Most 14, 1967, 143-168. J. Lepiksaar: Osteologia. I. Pisces. Privately distributed. Göteborg 1983.

R. M. Libois/C. Hallet-Libois: Éléments pour l'identification des restes crâniens des poisons dulçaquicole de Belgique et du Nord de la France. 2 - Cypriniformes. In: J. Desse/N. Desse-Berset (ed.): Fishes d'ostéologie animale pour l'archéologie 4. Série A: Poissons. Paris 1988, 1-21.

A. Lombardini: Zoborské opátstvo. Tovaryšstvo 2, 1895 115-124.

H. Lorenz: Domenico Martinelli und die österreichische Barockarchitektur. Wien 1991.

V. Ložek: Měkkýši československého kvartéru. Praha 1955.

V. Lučivjanská: Mäkkýše Zobora a jeho predpolia. Zobor 2, 1991, 17-38.

R. L. Lyman: Vertebrate taphonomy. Cambridge 1994.

D. Makowiecki: The usefulness of archaeozoological research in studies of the „reconstruction" of the natural environment. Archaeozoologia 21, 2003, 103-120.

D. Makowiecki: Historia ryb i rybołówstwa w holocenie na Niżu Polskim w świetle badan archeoichtiologicznych. Poznań 2003.

P. Maliniak: Človek a krajina Zvolenskej kotliny v stredoveku. Banská Bystrica 2009.

A. F. C. Marsigli: Danubius Pannonicp-Mysticus, observationibus geographicis, astronomicis, hydrographicis, historicis, physicis perlustratus et in sex tomos digestus. Tomus quartus de Piscibus Danubii. Hagae Comitum. Amsterodami 1726.

Z. Miklíková: Archeozoológia. In: G. Březinová/M. Samuel a kol.: Tak čo, našli ste niečo? Svedectvo archeológie o minulosti Mostnej ulice v Nitre. Nitra 2007, 127-130.

Z. Miklíková: Archeozoologické nálezy zo stredovekého sídliska v Bajči. Slovenská archeológia 58, 2010, 123-168.

Z. Miklíková/M. Fabiš: Zvyšky zvierat z mestskej tržnice v Nitre. In: V. Hašek/ R. Nekuda/M. Ruttkay (ed.): Ve službách archeologie V. Brno - Nitra 2004, 165-172.

F. Mikloško: Kamalduli. Impulz Revue 3, 2012. http://www.impulzrevue.sk/article. php?858 [05. 05. 2018]

J. Mjartan: L’udové rybárstvo na Slovensku. Klenotnica slovenskej l’udovej kultúry 14. Bratislava 1984.

E. Mohr: Der Wels. Die Neue Brehm Bücherei, Heft 209. Wittenberg Lutherstadt 1957.

A. Morales/K. Rosenlund: Fish Bone Measurements; An Attempt to Standardize the Measuring of Fish Bones from Archaeological Sites. Københaven 1979.

M. Moreno-García/C. Detry: The dietary role of hens, chickens and eggs among a $17^{\text {th }}$-century monastic order: the Clarisse of Santa Clara-a-Velha, Coimbra (Portugal). In: W. Prummel/J. T. Zeiler/D. C. Brinkhuizen (ed.): Birds in Archaeo- 
Mulitzer 2012

Mulitzer 2014

neznámy autor 1939

Novikmec/Svitok 2015

O’Day/Van Neer/Eroynck/2003

Oliva/Hrabě/Lác 1968

Ottův Malý slovník náučný

Patoka a i. 2014

Patoka/Kocánová/Kalous 2016

Pluskowski a i. 2010

Pomfyová 2015

Poštulka 2011

Pucher 1991

Radu 2003

Randík a i. 1971

Rebourg a i. 2003

Regula sv. Benedikta 2010

Reitz/Wing 1999

Repka/Sater/Šimunková 2017

Samuel 2009

Samuel 2010

Samuel 2011

Samuel, v tlači

Samuel/Čurný 2010

Samuel/Tirpák 2012

Sedlár 1954

Sedlár 1959

Sedlár 1969

Serjeantson 2009 logy. Proceedings of the $6^{\text {th }}$ meeting of the ICAZ Bird Working Group in Groningen (23. 8.-27. 8. 2008). Groningen 2010, 45-55.

M. Mulitzer: Die amerikanischen Einsiedeleien der Kamaldulenser von Monte Coronal Camaldolese hermitages of the Congregation of Monte Corona in America/Los yermos de los Camaldulenses de Monte Corona en las Américas. Salzburg 2012.

M. Mulitzer: Monastion Coronense II. Die Architektur der Kamaldulenser-eremiten von Monte Corona in Europa. Salzburg 2014.

Z kroniky Zoborského kláštora. In: Hlasy z domova a z misií 25/7, b. m. v. 1939, 198-203.

M. Novikmec/M. Svitok: Rak riečny Astacus astacus (Linnaeus, 1758). In: M. Janák/ J. Černecký/A. Saxa (ed.): Monitoring živočíchov európskeho významu v Slovenskej republike. Výsledky a hodnotenie za roky 2013-2015. Banská Bystrica 2015, 116, 117.

S. J. O'Day/W. Van Neer/A. Ervynck: Behaviour Behind Bones: the Zooarchaeology of Ritual, Religion, Status and Identity. Oxford 2003.

O. Oliva/S. Hrabě/J. Lác: Stavovce Slovenska I. Ryby, obojživelníky a plazy. Bratislava 1968. Kolektív autorov: Ottův Malý slovník náučný. Zväzok I, II. Praha 1904.

J. Patoka/M. Nývltová Fišáková/L. Kalous/P. Škrdla/M. Kuca: Earliest evidence for human consumption of crayfish. Crustaceana 87, 2014, 1578-1585.

J. Patoka/B. Kocánová/L. Kalous: Crayfish in Czech cultural space: the longest documented relationship between humans and crayfish in Europe. Knowledge and Management of Aquatic Ecosystems 417, 2016, 5.

A. Pluskowski/G. K. Kunst/M. Kucera/M. Bietak/I. Hein: Bestial Mirrors. Using Animals to Construct Identities in Medieval Europe. Animals as Material Culture in the Middle Ages 3. Vienna Institute for Archaeological Sciences. Wien 2010.

B. Pomfyová: Kláštory a kapituly. In: B. Pomfyová (zost.): Stredoveký kostol. Historické a funkčné premeny architektúry. 1. zväzok. Bratislava 2015, 249-324.

V. Poštulka: Labužníkovy historky. 66 př́běhů z kulinářské historie. Praha 2011.

E. Pucher: Der frühneuzeitliche knochenabfall eines Wirtshauses neben der Salzburger Rezidenz. In: Salzburger Museum Carolino Augusteum Jahresschrift 35/36 1989/1990. Salzburg 1991, 71-135.

V. Radu: Exploitation des resssources aquatiques dans les cultures néolithiques et chalcolithiques de la Roumanie Méridionale (Thèse de doctorat, Université d'Aix-Marseille I). Aix-Marseille 2003. Nepublikované.

A. Randík/J. Voskár/D. Janota/A. Tokarský: Rozšírenie a ochrana korytnačky močiarnej (Emys orbicularis L.) v Československu. In: Československá ochrana prírody 12. Bratislava 1971, 27-59.

C. Rebourg/M. Chastanet/B. Gouesnard/C. Welcker/P. Dubreuil/A. Charcosset. Maize introduction into Europe: the history reviewed in the light of molecular data. Theoretical and Applied Genetics 106, 2003, 895-903.

Regula sv. Benedikta: Mnísi z rehole sv. Benedikta 2. Sampor 2010.

E. J. Reitz/E. S. Wing: Zooarchaeology. Cambridge Manuals in Archaeology. Cambridge 1999 .

D. Repka/P. Sater/K. Šimunková: Archeologické nálezy z Oponického hradu. Študijné zvesti AÚ SAV 62, 2017, 181-206.

M. Samuel: Nálezy skla z archeologického výskumu Zoborského kláštora. Študijné zvesti AÚ SAV 46, 2009, 45-50.

M. Samuel: Najnovšie výsledky archeologických výskumov Zoborského kláštora v Nitre. Monumentorum Tutela 22, 2010, 276-287.

M. Samuel: Výskumy v areáli Zoborského kláštora v Nitre. AVANS 2008, 2011, 236-238.

M. Samuel: Architektúra mníšskych príbytkov kamaldulského kláštora sv. Jozefa v Nitre na Zobore. In: M. Bača (ed.): Zborník k 70. narodeninám Michala Slivku. Pod stromom života. Bratislava, v tlači.

M. Samuel/M. Čurný: Pottery from the cellar of a monastic dwelling at the Kamaldul monastery in Nitra-Zobor. In: J. Žegklitz (ed.): Studies in Post-medieval Archaeo$\log y$ 4. Written and iconographic sources in post-medieval archaeology. Praha 2010, 429-452.

M. Samuel/J. Tirpák: Najnovšie výsledky nedeštruktívnej prospekcie zoborského kláštora v Nitre. Študijné zvesti AÚ SAV 52, 2012, 51-62.

J. Sedlár: Rybárstvo. Bratislava 1954.

J. Sedlár: Ryby povodia rieky Nitry. Polovníctvo a rybárstvo 2, 1959, 14, 15.

J. Sedlár: Súčasný stav zarybnenia povodia rieky Nitry. Biologické práce 15, 1969, 5-78.

D. Serjeantson: Birds. Cambridge Manuals in Archaeology. Cambridge 2009. 
Schmid 1972

Silver 1969

Speller a i. 2010

Stloukal 2008

Stloukal/Vitázková/Janák 2013

Stoličná-Mikolajová 2001

Šimunková/Beljak Pažinová 2017

Števík/Timková 2004

Takáč 1997

Thieren/Van Neer 2016

Thornton a i. 2012

Točka 2017

Tomčík 2008

Uerpmann 1973

Urban 2007

Urban/Kadlečík/Kadlečíková 2012

Valachovič 2008

Valachovič/Hanzelová/Špakulová 2012

Vozák 2014

Vozák/Bielich, v tlači

Vozár 1997

Vörös 2003

Wheeler/Jones 1989

Willis/Eren/Rick 2008

Záleský 1922

Záleský 1925

Záleský 1927

Zeuner 1963

Zíbrt 2012
E. Schmid: Atlas of animal bones. Amsterdam - London - New York 1972.

I. A. Silver: The ageing of domestic animals. In: D. R. Brothwell/E. S. Higgs (ed.): Science in archaeology a survey of progress and research 2. New York 1969, 250-268.

C. F. Speller/B. M. Kemp/S. D. Wyatt/C. Monroe/W. D. Lipe/U. M. Arndt/D. Y. Yang: Ancient mitochondrial DNA analysis reveals complexity of indigenous North American turkey domestication. Proceedings of the National Academy of Sciences of the USA 107, 2010, 2807-2812.

E. Stloukal: Distribution of native crayfish in Western Slovakia. Folia Faunistica Slovaca $13,2008,79,80$.

E. Stloukal/Vitázková/Janák: Metodika monitoringu výskytu a stavu populácií raka riečneho (Astacus astacus) na Slovensku. Folia faunistica Slovaca 18, 2013, 233-250.

R. Stoličná-Mikolajová: Kuchyňa našich predkov. Bratislava 2001.

K. Šimunková/N. Beljak Pažinová: Konzumácia mäsa na hradoch v novoveku: prípadová štúdia z hradu Dobrá Niva. Archeologia historica 42, 2017, 511-521.

M. Števík/M. Timková: Červený (Lechnický) kláštor. Stará L’ubovňa 2004.

P. Takáč: Pochútka s klepetami. Podarí sa obnovit chov rakov na Slovensku? Quark 5, 1997, 18-20.

E. Thieren/W. Van Neer: Scutes for Sturgeon Siye Reconstruction: Traditional and Geometric Morphometric Techniques Applied to Acipenser sturio and A. oxyrinchus. Archaeofauna 25, 2016, 15-32.

E. K. Thornton/K. F. Emery/D. W. Steadman/C. Speller/R. Matheny: Earliest Mexican Turkeys (Meleagris gallopavo) in the Maya Region: Implications for Pre-Hispanic Animal Trade and the Timing of Turkey Domestication. PLoS ONE 7(8): e42630. doi:10.1371/ journal.pone.0042630 [12. 4. 2018]

I. Točka (zost.): Spomienky Zoborčanov. Nitra 2017.

V. Tomčík: $S$ vareškou dvoma tisícročiami. Kapitoly z dejín bratislavskej kuchyne a receptami našich predkov. Bratislava 2008.

H.-P. Uerpmann: Animal bone finds and economic archaeology: a critical study of "osteo-archaeological" method. World Archaeology 4, 1973, 307-322.

P. Urban: Rozšírenie raka riečneho (Astacus astacus) v južnej časti stredného Slovenska. In: J. Galvánek (ed.): Zborník múzeí Banskobystrického samosprávneho kraja, Stredné Slovensko 11. Banská Bystrica 2007, 55, 56.

P. Urban/J. Kadlečík/Z. Kadlečíková: Vydra riečna Lutra lutra. In: J. Krištofík/ Š. Danko (ed.): Cicavce Slovenska - rozšírenie, bionómia a ochrana. Bratislava 2012, 440-447.

D. Valachovič: Program záchrany bobra vodného (Castor fiber Linné 1758). Banská Bystrica 2008. http://www.sopsr.sk/cinnost/programy/PZ_Castor_fiber.pdf [06. 04. 2018]

D. Valachovič/V. Hanzelová/M. Špakulová: Bobor eurázijský (európsky, vodný) Castor fiber. In: J. Krištofík/Š. Danko (ed.): Cicavce Slovenska - rozšírenie, bionómia a ochrana. Bratislava 2012, 81-85.

Z Vozák: Archeozoologická analýza nálezov z Lietavského hradu z rokov 2008-2010. In: Kol. autorov: Hrad Lietava 2003-2013. Zborník z vedeckej konferencie konanej dňa 20.-21. júna 2014 na hrade Lietava. Lietava 2014, 100-103.

Z. Vozák/M. Bielich: Konzumácia mäsa na hradoch v novoveku: porovnávacia štúdia hradu Gýmeš a Lietava. In: M. Bača (ed.): Zborník k 70. narodeninám Michala Slivku. Pod stromom života. Bratislava, v tlači.

J. Vozár: Archívy kamaldulských kláštorov zo Slovenska v Budapešti. In: J. Dorul’a (ed.): O prekladoch Biblie do slovenčiny a do iných slovanských jazykov. Bratislava 1997, 84-93.

I. Vörös: Sixteenth and Seventeenth century Animal Bone Finds in Hungary. In: I. Gerelyes/Gy. Kovács (ed.): Archeology of the Ottoman Period in Hungary. Papers of the conference held at the Hungarian National Museum, Budapest, 24-26 May 2000. Opuscula Hungarica III. Budapest 2003, 351-364.

A. Wheeler/A. K. G. Jones: Fishes. Cambridge 1989.

L. M. Willis/M. I. Eren/T. C. Rick: Does butchering fish leave cut marks? Journal of Archaeological Science 35, 2008, 1438-1444.

M. Záleský: O chovu želv na rybnících Třeboňska a Hlubocka v XVII. až XVIII. století. Československý Rybář 2, 1922, 36-38, 48-49.

M. Záleský: Želvy pana Petra Voka z Rožmberku na Třeboni. Akvaristické listy 4, 1925, 61.

M. Záleský: Aklimatisace želv v našich krajích. Věda př́rodní 8, 1927, 140-143.

F. E. Zeuner: A History of Domesticated Animals. New York 1963.

Č. Zíbrt: Česká kuchyně za dob nedostatku. Praha 2012. 


\title{
Fish and Fasting in the Zobor Monastery in Nitra in the Light of Archaeozoological Evidence
}

\author{
Zora Bielichová - Marián Samuel - Karol Hensel
}

\author{
Summary
}

The Camaldolese monastery of St. Joseph in Nitra, Zobor, was established at the end of the $17^{\text {th }}$ century right at the location where the oldest Benedictine monastery of St. Hypolite $\left(9^{\text {th }} /\right.$ the early $11^{\text {th }}$ century-the end of the $15^{\text {th }}$ century) had been standing (Fig. 1). After almost two centuries, the Bishop of Nitra, Baron Blažej Jaklin from Lefantovce, and his cousin, the Nitra castle captain Baron Nicolas Jaklin decided to revive the monastery life. On 28 June 1691 , they elaborated a document in Nitra in which they were expressing their will to fund construction and functioning of the monastery equally for an unlimited period. The monastery was built for 12 monks of the Camaldolese order. The founders announced their plan to King Leopold I, who allowed use of rents from the Pilis Abbey to provide for the functioning of the monastery in his letter of recommendation from 5 September 1691. After the negotiation and approval of the project by the General Chapter of the Camaldolese order in 1692, the Cardinal Leopold Kolonič officially confirmed the establishment of a hermitage of St. Joseph on the hill of Zobor by a decree from 14 March 1693. It was finished in 1695 or 1697, however, the monks' dwellings were also built later, according to needs and available funds; their final number is 18. The monastery on Zobor was one of the first five Camaldolese monasteries in the Austrian monarchy. They all belonged to the reform congregation of Monte Corona. The first - and the only for a long time - Camaldolese hermitage built to worship St. Joseph similarly to the one in Nitra was initiated by Emperor Ferdinand II less than $8 \mathrm{~km}$ from the centre of Vienna, on the hill of Kahlenberg in 1628. Construction of the second monastery in the Austrian part of the monarchy dedicated to Archangel Michael on the hill near Lánzsér in the Sopron County was funded by Palatine Paul Esterházy and his wife Eva Thököly in 1700. There were three monasteries in the Hungarian part of the monarchy. The Monastery of St. Joseph in Nitra, on Zobor hill, was first. Founding of another was initiated by Ladislav Matašovský, the Bishop of Nitra, the successor of Blažej Jaklin. In 1705, he donated a former Carthusian monastery in the Lechnická dolina valley in Spiš to the Camaldolese order. The third Camaldolese monastery in Hungary - devoted to John of Nepomuk - was established near the extinct Carthusian monasery by count Joseph I Esterházy in 1733 in the Komárom County, near the village of Majk. These five monasteries made an organizational unit called Hermitages of the German-Hungarian nation (Eremi Nationis Germano-Hungaricae). It was one of the five nations into which the Camaldolese congregation of Monte Corona was divided in the 18th century. Other nations were: church, or papal (in Central Italy, in the territory of the former papal state), Neapolitan, Venetian and Polish. All Camaldolese monasteries in the Austrian monarchy were abolished by a decree of Joseph II in 1782. Since then, the monastery on Zobor has been disintegrating, only a part of the main outbuilding of the convent, a ruin of the monastery church and parts of walls enclosing the monastery's terraces have been preserved. The design of the monastery is known only thanks to several preserved iconographic sources (Fig. 2) and - partly - thanks to the previously executed archaeological investigations. They revealed that the monastery on Zobor was a considerably large $(162 \times 165 \mathrm{~m})$ structure built on several man-made terraces. The inner area of the monastery delineated by a masoned enclosure and buildings occupied an area of almost 2.3 ha. The central part of the area was symmetrically composed; in the middle, there was the monastery church three naves of basilica type with a tower erected in the middle of the southern nave. Double lines of monks' dwellings were arranged along the sides of the church. The third line of small dwellings was standing east of the church, on the highest terrace of the monastery. On the western side, two inner lines of dwellings were attached to the side wings of the convent's main outbuilding. The outbuilding had two above-ground floors and three wings creating a U-shaped groundplan. North of this building, a smaller one-floor outbuilding with two wings was standing, other utility buildings were situated near the enclosure walls. A complex technical structure - a stone aquaduct - was part of the monastery since 1704. It brought water to the monastery from the so-called Svorad's spring and distributed it to rooms of the monastery, loundry rooms, fountains and tanks by multiple branches. Unused water filled two ponds below the monastery. The preserved plan of the monastery contains information on location of several buildings associated with food (refectory, kitchen, two meat kitchens, cook's room) and storage of foodstuffs (storage of fat and oil, fruit, wine) and their production (bakery, vegetable and fruit gardens, greenhouses, hotbeds, pigsties; Fig. 3).

Several rescue and evaluation archaeological excavations have been carried out at the site. During the first excavation in 1940, a couple of Baroque monk dwellings were uncovered together with a small part of a medieval monastery. Unfortunately, documentation and finds from this research were burnt during the bombing of Bratislava at the end of WWII and a short informative article on the results of the research does not mention any finds related to the topic of monks' alimentation. The successive rescue research in 1960-1961 paid no attention to this topic either.

A few evaluation excavations were carried out as late as 2001-2003 and 2008, when it was possible to study part of the former monasteries' areas more systematically, especially the area south of the ruins of the St. Joseph Church (Fig. 5). There, remains of three monk dwellings were partially uncovered. With regard to the studied topic, finds from dwellings 3 and 9 were particularly important. A considerable part of our assessed material (82.5\%) comes 
from dwelling 9 and its housekeeping room. The room was used mainly for storing wood and it was divided into two parts (Fig. 6). The smaller part was made by a sunken, originally vaulted, masoned space with a ventilation (?) shaft and earthen floor. It could have been a small cellar or a waste shaft (cesspit?) of a toilet (Fig. 7). A large amount of archaeological material including a collection of pottery and glass vessels well representing the scale of products associated with dining and alimentation was discovered in the backfill of this area. Other samples come from monk dwelling 3 and its immediate surroundings. There are samples of disturbed floors, from layers below them and other postmedieval contexts. One sample comes from a medieval feature and two come from layers representing the horizon of disintegration of the medieval monastery.

The obtained collection comprises 5,201 archaeozoological finds including bones, teeth and egg shells. Their taxonomic analysis revealed mammals (Mammalia), birds (Aves), reptiles (Reptilia), fish (Osteichthyes), crustaceans (Crustacea) and molluscs (Mollusca). 20 animal species were identified - 12 wild and 8 domestic (Tab. 2). Wild animals prevail by their number $(94.2 \%)$, mass of finds (50.8\%) as well as the minimum number of individuals (69.9\%). Unlike the assortment including common farm and wild species from the region, their representation among the bones in the studied collection is considerably different from the previously studied archaeological sites from the Early Modern period in Nitra and its wider surroundings (Fig. 8).

Among domestic animals, all common farm species - with the exception of goat - are represented: cattle (Bos taurus), pig (Sus domesticus), sheep (Ovis aries), horse (Equus caballus), dog (Canis familiaris), chicken (Gallus domesticus), goose (Anser domesticus) and turkey (Meleagris domesticus). Almost half of the finds of the domestic fauna comprises bones and teeth of sheep/goat $(n=63=2.6 \%$ NISP), followed by poultry $(n=26=1.0 \%$ NISP), cattle $(n=26=1.1 \%$ NISP) and pig $(n=15 / 16=0.6 \%$ NISP). From the aspect of the species early occurrence, the find of an os coracoideum sinistra from turkey ( $n=1=0 \%$ NISP) is interesting. It represents a first record of keeping of this species of bird in the studied area, which was part of the Hungarian Kingdom in the 18th century (Fig. 11: 2). Comparison of the find with populations of the original wild turkey from Mexico showed that the bone most probably comes from a non-adult female. A trace of human activity (a cut) indicated manipulation with the bird's body by a human, probably with the aim to separate a wing from the body. Thus, we assume that turkey meat was part of the diet, although exact chronological classification to the Camaldolese monastery is disputable. This find comes from a non-clearly dated context - from sample 4 obtained from under the floor in hermitage 3 and was accompanied by other bones from poultry and domestic mammals. Our knowledge of the time of import of turkey to Europe, however, exludes possible association of the find with the older medieval period, thus, consumption of turkey meat and other domestic animal species could possibly be associated with the numerous ancillaries and servants in the monastery who were not tied by the strict rules of the monks' diet (pigsties were also part of the monastery's area, according to the preserved plan).

The assortment of wild animals includes groups of terrestrial (2), semi-aquatic (3) and aquatic species (7). Bones and a tooth of a small rodent ( $\mathrm{n}=3=0.1 \%$ NISP) were identified as edible dormouse (Glis glis). Althoug meat from dormouse or squirrel was a natural part of human diet as late as the Postmedieval period, it is more than probable that in our situation, the individuals found in sample 12 (Fig. 12: 1) are a result of natural settlement and death after the extinction of the cellar in hermitage 3. On the other hand, finds of bones from beaver and otter ( $\mathrm{n}=9=0.4 \%$ NISP) clearly correspond with the context of the diet in the monastery. The Eurasian beaver (Castor fiber) - similarly to the Eurasian otter (Lutra lutra) - became extinct in Slovakia in the 19th century. The pond near the monastery could have attracted them to settle there if there was enough fish and vegetation. Both species have been absent in the regional archaeozoological records from the Postmedieval period and were probably imported to the monastery in association with providing maigre meat. Remains of these species come from the interior of dwellings 3 and 9 (Tab. 3). Beaver is represented by the ischium (corpus ossis ischii $d x$.) and a tooth (molar sup./inf.) of at least one, probably adult, individual (Fig. 12: 2). The body of the ischium was cut through by a human hand on both ends (by a tool with a sharp blade), possibly during butchering/cooking. Otter bones represent remains of at least two individuals (Fig. 12: 3). A non-adult otter is represented by the proximal part of a femur and a vertebra, an adult individual is represented by fragments of a skull with teeth (parietale sin., maxilla et dens sin., et $d x$., mandibula et dens, $d x$.) and two tail vertebrae (vertebrae caudalis). Parts of the skull and mandible bear old fracture lines which could be related to processing of meat in the kitchen, maybe with consumption of the brain tissue and the tongue muscle. In the context of these finds of animals in the monastery, we can also consider other benefits, e. g. castoreum from the castor sacs of beavers which was used to reduce spasms or make parfumes. In healing practised also by the Camaldolese monks, beaver and otter fat, blood, teeth and bones were used as well.

Another group of finds ( $\mathrm{n}=14=0.6 \%$ NISP) contained bones of the European pond turtle (Emys orbicularis). Not long ago, this reptile occured in inundation areas of Slovak rivers, including the Nitra. Bibliographical as well as archaeozoological sources document also its breeding in Baroque monasteries (e. g. in Austrian Mauerbach), where they were an important part of meaty food of monks, together with fish. It can be assumed that they were part of the diet at the Zobor monastery as well. Evidence for this can be seen in the visible traces of human activity (cuts, division of bones) on the preserved parts of skeletons (Fig. 13: 1). In the context of archaeozoological finds from the territory of Slovakia, this is very rare evidence of consumption of pond turtles in the past.

The most numerous group of assessed finds $(n=4824=91.5 \%$ NISP) from the Zobor monastery contains fish bones (Fig. 14-17). With the exception of two fragments, they all come from interiors of monk dwellings. Exclusive presence of local freshwater fish species was detected, such as the northern pike (36.9\%), common carp (27.2\%), wels catfish $(3.5 \%)$, sturgeon $(1 \%)$ and common bleak $(0.1 \%$ in total). Some of the found bones confirm consumption of rather large individuals (e. g. pike of 90-110 cm/7-11 kg, carp of 90-110 cm/12-20 kg, catfish of 140-180 cm/35-40 kg). The find of a bone from a 33-35-year-old catfish with estimated body length of $264 \mathrm{~cm}$ and weight of $123 \mathrm{~kg}$ is absolutely 
unique (Fig 16; Tab. 7). It is one of the largest historically documented catfish from the territory of Slovakia (the current European record is $274 \mathrm{~cm}$ ).

Rare archaeozoological finds include fragments of a shells of probably European crayfish (cf. Astacus astacus) that used to be consumed in monasteries but also by rich noblemen and aristocracy in the time of fasting (Fig. 18).

The anatomical composition of the discovered bones (Tab. 8) confirms that whole fish arrived in the kitchen, most of them still alive, and the two tanks at the courtyard of the convent's main building were used to keep them alive. Metrical analysis of the remains showed that larger individuals were processed most often, fulfilling the requirements for organized catering and adequate benefit of meat. Fish and other foodstuffs of animal origin could have been obtained by the Camaldolese monks by purchase, as gifts, or by means of their own keeping of farm animals and cultivation of ponds whose existence and location on Zobor hill is proved by several contemporary sources. Large catfish, on the other hand, point to purchase and import of fish. Cooked meat was served in hermits' dwellings as part of individual diet. Finds from an enclosed context - the cellar of hermit dwelling 9 - point to the strictly followed rules and long-term consumption of maigre food by its inhabitant. As for animal food, fish was documented there; meat of otter, shellfish, chicken and egg were the complements. Further finds from other sites, on the contrary, suggest less restrained food. They are evidence of consumption of the "allowed" meat from pond turtles and beaver, but also of the "forbidden" meat of cattle, sheep, or pig and chicken. However, the contexts in which they were found are important. Moreover, we must take the following into consideration - besided monks following the strict rules of diet, a considerable number of people who did not follow them were present in the monastery. It was not only the numerous servant stuff, but also other people from outside the monastery either visiting or spending the rests of their lives there, as mentioned by the preserved written sources. A large number of samples of "non-maigre" food is probably related to the period of the monastery's construction and the period after the end of its functioning. New, more detailed information related to the topic of diet, processing and production of foodstuffs in the Camaldolese monastery of St. Joseph in Nitra, on Zobor hill, could be brought by further investigation of other parts of the monastery as well as unprocessed archival sources, e. g. books of accounts.

Fig. 1. Location of the Zobor monastery on the map from 1st military mapping (1782-1784).

Fig. 2. Nitra-Zobor monastery. Oil painting from the second half of the $18^{\text {th }}$ century depicting the area of the Camaldolese Monastery of St. Joseph. Nitra Gallery, an unknown Central European artist. Inv. no. 0-81. Photo by M. Samuel.

Fig. 3. Digitalized plan of the Camaldolese monastery of St. Joseph in Nitra, Zobor hill, from the $18^{\text {th }}$ century with indicated location of monk dwellings 3 and 9 and functions of individual rooms and spaces. Bold - spaces related to alimentation, large-sized numbers - monk houses mentioned in paper. According to the plan by Cristoph Schlegel, digitalized by M. Samuel. The original of the plan is deposited at the Magyar Országos Levéltár Budapest, sign. S12. Div. 9, No. 60: 1-2. Translation of the text addendum to the plan by R. Ragač.

Fig. 4. From the life of Camaldolese monks in Bielany (Poland). Archive photos from 1930 and 1934. Source: www.http:// krakow.naszemiasto.pl/artykul/klasztor-na-bielanach-przed-wojna-zdjeca,3157653,artgal, t,id, tm.html (edited).

Fig. 5. Plan of the studied areas south of the line of monk dwellings from investigations in 1942 and 2001-2003; a - uncovered medieval masonries of the Benedictine monastery of St. Hypolite and their assumed line; $b-$ medieval features; c - uncovered/assumed line of masonries of the Camaldolese monastery of St. Joseph; $\mathrm{d}$ - Baroque stone aquaduct with a fountain; e - borders of studied areas in 1942 and 2001-2003. Plan by M. Samuel.

Fig. 6. Groundplan of monk dwelling 9 and profiles of the "cellar": A - chapel; B - hallway; C - the main residential room; D - office; E - housekeeping room with the "cellar" space; 1 - exterior stone tiles; 2 - brick floor of the hallway; 3 - above-ground stone masonry; 4 - assumed line of the masonries of the monk dwelling; 5 - wooden plank of a treshold; 6 - incompact remains of the brick floor; 7 - brick plinth of a heating device; 8 - brick floor; 9 -incompact mortar floor; 10 - earthen floor of the cellar; 11 - mortar tongue; 12 - pole pits; 13 - ventilation shaft; 14 - remains of brick vault; 15 - mortar floor; 16 - brick plinth of the altar; 17 - profiled ledge of the altar plinth; 18 - pit (medieval?). Plan by M. Samuel.

Fig. 7. Northern view of the "cellar" space of the housekeeping room of monk dwelling 9. Photo by M. Samuel.

Fig. 8. Representation of taxons (\% NISP) in the material from the Zobor monastery and other postmedieval sites from the region of Nitra. 1 - complete assortment; 2 - domestic species.

Fig. 9. Nitra-Zobor monastery. Representation of taxons in trenches (\% NISP). 1 - trench 2/03 ( $\sum=375$; dwelling 3); 2 - trench 4/04/03 ( $\sum=2025$; dwelling 9).

Fig. 10. Nitra-Zobor monastery. Anatomic structure in the group of farm animal species. Dog and horse not included. 1 - share of bones (\% NISP) according to qualitative categories. A - top quality meat; B - medium quality meat; $\mathrm{C}$ - butcher waste; 2 - share of bones of A and B categories (\% WISP) in the total weight of bones with flesh (723.5 g). Legend: $\mathrm{a}$ - cattle; $\mathrm{b}$ - sheep/goat; c - pig; d - poultry.

Fig. 11. Turkey (Meleagris gallopavo f. domestica). 1 - a turkey on an illustration from Historiae Animalium (16 ${ }^{\text {th }}$ century) by C. Gessner. Source: http://dx.doi.org/10.3931/e-rara-1946 (edited); 2 - os coracoideum of a turkey from the Zobor monastery (ventral, lateral and dorsal view). Arrow - localization of a miniature cut. Photo by Z. Bielichová.

Fig. 12. Wild mammals. 1 - edible dormouse (Glis glis), 2 - incisor and part of cut ischium of Eurasian beaver (Castor fiber) from the Zobor monastery; 3 - femur and vertebra of a non-adult individual and fragments of neurocranium, maxila and mandibula, two tail vertebrae of an adult individual of Eurasian otter (Lutra lutra) from the Zobor monastery; 4 - otter and beaver on an illustration from Historiae Animalium ( $16^{\text {th }}$ century) by Conrad Gessner. Source: http://dx.doi.org/10.3931/e-rara-1956 (edited). Human activity indicated by the arrow. Photo by Z. Bielichová. 
Fig. 13. The European pond turtle (Emys orbicularis). 1 - bones from the Zobor monastery of at least four individuals of different size and age; 2 - pond turtle on an illustration from Danubius Pannonico-Mysticus (1726) by L. F. Marsigli. Source: www.europeana.eu, (edited); 3 - breeding of turtles on an illustration from Georgica curiosa (1682) by W. H. Hohberg. Source: http://digital.bibliothek.uni-halle.de (edited). Human activities indicated by the arrow. Photo by Z. Bielichová.

Fig. 14. Nitra-Zobor monastery. Sturgeon (Acipenser sp.). 1 - schematic representation of localization of rows of osseous plates on a fish body. Source: Thieren/Van Neer 2016, 17, fig. 1 (edited); 2 - dorsal plates from a small individual; 3 - completely or partly preserved plates from various fish body parts; human activities indicated by the arrow. Photo by Z. Bielichová.

Fig. 15. Nitra-Zobor monastery. Pike (Esox lucius) and Ćyprinidae fish. 1 - Esox lucius, os dentale of large individuals; 2 - Esox lucius, two vertebrae cut transversally to the axis of the fish body; 3 - Esox Lucius, deformed vertebrae; 4 - Cyprinus carpio, detail of the os hyomandibulare with the cut; 5 - Cyprinus carpio, cross-section of os pharyngeale; 6 - os pharyngeale with a row of teeth, a - Alburnus Arburnus; b - Tinca tinca; c - Leuciscus leuciscus; $\mathrm{d}$ - Cyprinus carpio; 7 - cf. Cyprinus/Silurus, vertebrae with cuts parallel with the body axis; 8 - cf. Cyprinus/Silurus, vertebrae with cuts transversal to the body axis; 9 - cf. Cyprinus/Silurus, deformed vertebrae. Human activities (selected) indicated by the arrow. Photo by Z. Bielichová.

Fig. 16. Nitra-Zobor monastery. Size of consumed fish (histograms). 1 - Esox lucius (NISP = 173); 2 - Cyprinus carpio (NISP = 150); 3 - Silurus glanis (NISP = 44). TL - total length of the fish body including tail.

Fig. 17. Nitra-Zobor monastery. Wels catfish (Silurus glanis). 1 - os dentale (lef) and fragment of os vomere (right); 2 - pinnae pectorales with multiple cuts and cut off tips; 3 - large os cleithrum with cuts on both ends; 4 -os operculum; 5 -oc ceratohyale; 6 - os cleithrum with an artificial opening, ventral and dorsal view; 7 - three vertebrae abdominales (approx. 14.-19.) of fish with the size of approx. $175 \mathrm{~cm} / 35 \mathrm{~kg}$ and $17-18$ years old. Human activities indicated by the arrow. Photo by: Z. Bielichová.

Fig. 18. Nitra-Zobor monastery. Fragments of the shell from pincers, cephalothorax and abdomen of one or several individuals of the European crayfish (cf. Astacus astacus). Photo by Z. Bielichová.

Tab. 1. Nitra-Zobor monastery. List of analyzed samples from 2003.

Tab. 2. Nitra-Zobor monastery. Assortment and representation of animal taxa in the collection.

Tab. 3. Nitra-Zobor monastery. Representation of taxa in the samples (by numbers).

Tab. 4. Nitra-Zobor monastery. Anatomic composition in the group of domestic animals (by the number and weight in grams).* - total of Ovis aries and Ovis/Capra; ${ }^{* *}-$ Sus cf. domesticus not included. Categories A, B and C indicate top, medium and poor quality and amount of flesh on bones (after Uerpmann 1973, complemented with poultry).

Tab. 5. Nitra-Zobor monastery. Estimated age at the time of death (without fish, by number of finds).

Tab. 6. Nitra-Zobor monastery. Occurence of butchering/kitchen activities (without fish, by number of finds).

Tab. 7. Nitra-Zobor monastery. Statistical parameters of length and weight of consumed fish. $n$ - number, TL - total body length, TW - total weight.

Tab. 8. Nitra-Zobor monastery. Anatomic composition within the group of fish bones (by number).

Translated by Mgr. Zora Bielichová (abstract) and Mgr. Viera Tejbusová (summary)

Mgr. Zora Bielichová

Archeologický ústav SAV

Akademická 2

SK - 94921 Nitra

zora.miklikova@savba.sk
RNDr. Mgr. Marián Samuel

Archeologický ústav SAV

Akademická 2

SK - 94921 Nitra

nrausamu@savba.sk

Prof. RNDr. Karol Hensel, CSc.

Prírodovedecká fakulta UK Bratislava

Mlynská dolina B-1

SK - 84215 Bratislava

hensel1@uniba.sk 